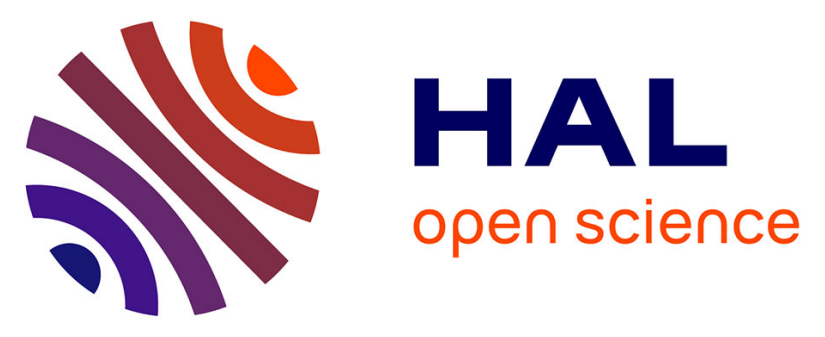

\title{
THE HAN RIVER AS THE CENTRAL AXIS AND THE PREDOMINANCE OF WATER: QUESTIONING THE CLAIM OF "NO CHU-RELATED TRAITS" IN THE VIEW OF TERRESTRIAL SPACE IN THE RONG CHENG SHI MANUSCRIPT (FOURTH CENTURY B.C.E)
}

Vera Dorofeeva-Lichtmann

- To cite this version:

Vera Dorofeeva-Lichtmann. THE HAN RIVER AS THE CENTRAL AXIS AND THE PREDOMINANCE OF WATER: QUESTIONING THE CLAIM OF "NO CHU-RELATED TRAITS" IN THE VIEW OF TERRESTRIAL SPACE IN THE RONG CHENG SHI MANUSCRIPT (FOURTH CENTURY B.C.E). Early China, 2021, 44, pp.143-235. 10.1017/eac.2021.7 . hal-03511306

\author{
HAL Id: hal-03511306 \\ https://hal.science/hal-03511306
}

Submitted on 4 Jan 2022

HAL is a multi-disciplinary open access archive for the deposit and dissemination of scientific research documents, whether they are published or not. The documents may come from teaching and research institutions in France or abroad, or from public or private research centers.
L'archive ouverte pluridisciplinaire HAL, est destinée au dépôt et à la diffusion de documents scientifiques de niveau recherche, publiés ou non, émanant des établissements d'enseignement et de recherche français ou étrangers, des laboratoires publics ou privés. 


\title{
Vera Dorofeeva-Lichtmann, CNRS, France
}

\section{The Han River as the Central Axis and the Predominance of Water: Questioning the Claim of 'No Chu-related Traits' in the View of Terrerstrial Space in the Rong Cheng shi manuscript ( $4^{\text {th }}$ c. BC).}

\author{
Early China, vol. 44 (2021): 143-235, doi:10.1017/eac.2021.7 \\ version below differs from the pubished in formatting and \\ contains some more details marked in grey
}

\section{Introduction}

A new account of the "Nine Provinces" (Jiu zhou 九州) discovered in the Rong Cheng $s h i$ 容成氏 (Mister Rong Cheng [?]) manuscript of Chu provenance dated to the late $4^{\text {th }}$ century $\mathrm{BC}$ has resulted in the immediate addition of this text to the list of the key early Chinese sources describing terrestrial space. Its importance is enhanced by the general rarity of manuscripts among early Chinese terrestrial descriptions, its description of the "Nine Provinces" being the only manuscript version known to date. However, it has close affinity with a wide spectrum of transmitted texts, and is distinguished by its combining of diverse spatial concepts with the central role of draining excess waters. Its eclectism thus throws more light on transmitted versions of the "Nine Provinces" than manifests any radically new or specifically Chu traits. This conclusion is true with

\footnotetext{
I am most grateful to Olivier Venture for remarks and suggestions on the first draft of this article, to Constance Cook for discussing and proof-reading the revised version during our stay as Visiting Fellows at the International Concortium for Research in the Humanities (IKGF) in Erlangen (summer 2016), to Sarah Allan and two anonymous reviewers for useful remarks on the revised version, and to John Moffett for the final corrections to my English. All mistakes found in this paper are my own reponsibility. I was preparing the manuscript for publication during my research stay at the Max Planck Institute for the History of Science in Berlin (July-September 2020) and considerably benefited from its excellent research facilities and most helpful staff. My special thanks are to Cathleen Paethe, the Subject Librarian for Sinology of the Institute.
} 
respect to the description proper of the "Nine Provinces" and is based on parallels with other texts. In this study I reassess this conclusion with respect to the context of this passage in the Rong Cheng shi, challenging an initial impression of its lack of any Chu flavour.

While the parallels of the new description of the "Nine Provinces" with those in transmitted texts has attracted considerable scholarly attention, its relation with other issues concerning terrestrial space in the Rong Cheng shi has not yet been studied. Before discussing the spatial issues in this manuscript, I shall first revise all the reconstructed sequences of its slips (Introduction). Then I shall focus on the especially controversial slip 31, which appears to be of primary relevance to spatial concepts (Part 1). It contains a reference to a "cosmograph"-like pattern followed by a description of managing landscape features, beginning with waterways. I shall discuss the place of this pattern in early Chinese cosmography, in particular, the link of the "policy statement" on the predominance of waters to the version of the "Nine Provinces" in the manuscript. I suggest that, from the point of view of the revealed spatial concepts, slip 31 should be placed prior to the group of slips that describe terrestrial disasters that preceded the establishment of the "Nine Provinces". Having concluded that the predominance of waters is the distinguishing feature of the representation of terrestrial space in the manuscript, and comparison with another cosmographical manuscript of Chu provenance contemporary with the Rong Cheng shi, the Chu Silk Manuscript no.1 (ca. late 4th century BC), I suggest that this feature may be characteristic of Chu descriptions of terrestrial space.

My main attention is focussed on solving the spatial problem in the conclusion to the "Nine Provinces", which up to now has been noted only in passing as somewhat confusing (Part 2). It provides a summary of structuring terrestrial space through waterways, and cuts the space thus mapped into southern and northern halves along the Han River. I argue that this unusual usage of the Han River as the central axis implicitely shifts the mapped area to the South, and thus conveys a Chu view of space, while explicitely respecting the spatial framework of transmitted descriptions of the "Nine Provinces". In addition to philological analysis of the descriptions of terrestrial space, I apply an innovative method of investigation of them through landmarks. Landmarks found in these descriptions, including the Han River, will be explored as elements of what can be tentatively defined as relational, positional or diagrammatic maps. Such maps are characteristic of traditional Chinese cartography. The earliest specimens covering the entire imperial realm date from the twelfth century onwards. Although the majority of these maps appeared as part of commentaries on early terrestrial descriptions and are products of a continuous tradition of representing space, they are rarely taken into consideration in studies of early texts. Finally, I discuss a 
correlation between structuring terrestrial space through waterways and the concept of Yu's personal and exhausting physical engagement in hard work (Part 3).

The description of the "Nine Provinces" with the related preceding and following slips slips 31 and 23-15-24-25-26-27-28-29 - is provided in the ANNEX).

\subsection{General characteristics of the Rong Cheng shi manuscript}

The Rong Cheng shi belongs to the Shanghai Museum Bamboo Slips Collection (Shangbo cangjian 上博藏簡). The corpus was purchased by the Shanghai Museum in 1994 in Hongkong. The precise location and date of this find are still unknown. Compared to manuscripts discovered in situ, looted manuscripts pose two major research problems - the lack of archeological context and thus their being, by definition, of questionable authenticity. ${ }^{1}$ There is general consensus that the Shanghai Museum corpus includes genuine manuscripts originating from a Chu aristocratic tomb closed shortly before the Chu court was obliged to leave the capital at Ying 郢 in $278 \mathrm{BC}^{2}$ No data contesting this point of view has been found to date.

The Rong Cheng shi is one of the largest (some 2000 characters) and best preserved manuscripts among the corpus. ${ }^{3}$ Its title is found on the verso of the last

\footnotetext{
${ }^{1}$ For a summary of problems with looted manuscripts, see Kern 2019, pp. 45-49; see also Lai and Wang 2017 and Hein (2019). For some methods for establishing fakes, see the article on one of the Tsinghua University manuscripts (acquired in 2008) by Jiang Guanghui 姜廣輝, Fu Zan 付贊, Qiu Mengyan 邱夢 燕 2013.

${ }^{2}$ Ying 郢 was the Chu capital from about 690 BC though 278 BC when it was occupied by Qin 秦, the kingdom that eventually absorbed all the ancient Chinese kingdoms and founded the Qin empire (221-207 BC). The precise location of Ying is unknown. Two possible locations - "Southern" and "Northern" - are proposed in relevant scholarly literature - Jinancheng 紀南城 and Chu Huangcheng 楚皇城, both in Hubei, see Blakely 1999, pp. 10-13; for Jinancheng, see also Guo Dewei 郭德維 1999. The discussion about Chu capitals has been given new life with the publication of the Chuju 楚居 (“Chu Settlements”) manuscript from the Qinghua University collection of Warring States bamboo slips (Qinghua Daxue cang Zhanguo zhujian 清華大學藏戰國竹簡), see Li Xueqin 李學勤, ed. 2011, even if the manuscript itself depicts rather the shift of the palaces of the Chu kings and not the shift of capitals, see articles by Shou Bin 守涁 and Taniguchi Mitsuru 谷口滿 in the 10th issue of the "Collection of Articles on Studies of Chu Culture” 楚文化研究論集 (2011) and Xin Deyong 辛德勇 2017, pp. 1-18. For an extensive discussion of the genealogy of Chu rulers, according to this manuscript, see Cook and Luo Xinhui 2017. I am grateful for details about recent studies to one of the anonymous reviewers.

${ }^{3}$ Due to damaged slips and obscure characters, a precise calculation of the total is not possible. It is, for instance, approximately equal in length to the "Yu gong" 禹貢 (“Yu's [System] of Tribute," ca. $5^{\text {th }}-3^{\text {rd }}$ century BC) chapter of the Shang shu 尚書 (Book of Documents), Shangshu zhengyi 尚書正義 (Sibu beiyao 四部備要 ed.), 6.1a-19b, systematically referred to below.
} 
among the originally identified 53 surviving slips of the manuscript. ${ }^{4}$ It is written as song cheng $d i$ 訟城氏, commonly accepted to stand for Rong Cheng shi 容成氏 Mister Rong Cheng. ${ }^{5}$ Rong Cheng shi is one the sage rulers of High Antiquity. ${ }^{6}$ The manuscript provides an overview of Chinese history, beginning from the mythical sage rulers through to the establishment of the Zhou dynasty (c. $1046-256$ BC). ${ }^{7}$ While

\footnotetext{
${ }^{4}$ Several slips at the beginning and in the end of the manuscript, and possibly a couple of slips in between, have deterioriated. Difference in lightness between characters on the recto and the verso of slip 53 and the possible discrepancy between the last character of the title and its analogues in the text (see the next note) allow one to conclude that the title was added later by another hand (Zhao Ping'an 趙平安 2003). This conclusion is now commonly shared (Niu Xinfang 牛新房 2010, pp. 75-76; Allan 2015, p. 187).

${ }^{5}$ In March 2005 I benefited from email communications with Wolfgang Behr, who revealed the complexity of identifying the 訟城氏 as a plausible phonetic loan characters for 容成氏, and can only regret that his notes have not been published. For an annotated list of investigations of the manuscript's title by Chinese scholars, see Sun Feiyan 孫飛燕 2010, p. 13. The identification of 訟城氏 with 容成氏 has to deal with the discrepancy between the characters designating "Mister" in the title of the manuscript and in the surviving names of the sage rulers in the main body of the manuscript: $d i$ 氏 $=s h i$ 氏 and shi 是, respectively. Sun Weilong 孙偉龍 \& Li Shoukui 李守奎 (2008) supposed that the bottom stroke in the 氏 may not be part of the character in the title, making it 氏, but this supposition, not largely supported, though simplifying the identification of the title still does not solve the discrepancy problem. Finally, there is a "stray" interpretation of the title that is still worth taking into consideration: it may not refer to Rong Cheng shi at all, but be the name of a person derived from a placename (Jao Tsung-I 饒宗頣 2006). Finally, the two translations of the manuscript into English by Yuri Pines and Sarah Allan contain regretful errors or misprints in the title transcription: Pines, 2010, p. 4, footnote 5, 訟成是 instead of 訟城 氏; Allan, 2015, p. 188, 成 instead of 城.

${ }^{6}$ For a brief analysis of the two presumably earliest references to the sage Rong Cheng shi in transmitted texts, which are found in the Zhuangzi 莊子 (4th-3rd cc. BC), as well as the occurrences of titles of two lost texts bearing his name listed in the "Yiwenzhi” 藝文志, the bibliographical treatise of the Hanshu 漢 書 by Ban Gu 班固 (AD 32-92), which relies on the lost bibliography Qilüe 七略 edited by Liu Xin 劉歆 (ca. 46 BC - AD 23), see Dorofeeva-Lichtmann 2010, pp. 15-16. For the sage rulers of High Antiquity enumerated at the beginning of the Rong Cheng shi manuscript and in transmitted texts, with a focus on the role of Rong Cheng shi, see Allan 2015, pp. 186-191. Among the transmitted texts referring to Rong Cheng shi is the somewhat overlooked overview of Chinese history in the "Benjing xun" 本經訓, chapter 8 of the Huainanzi 淮南子 (compiled shortly before $139 \mathrm{BC}$ ), which is especially interesting for its being typologically close to the Rong Cheng shi manuscript's historical narrative; Rong Cheng shi is also briefly mentioned to in the "Xiuwu xun” 修務訓, chapter 19 of the Huainanzi, see Huainan honglie jijie 1989, pp. 253-256 (ch.8) and 646 (ch.19); Le Blanc and Mathieu, trans. 2003), pp. 340-341 and 925-926; Major et al. 2010, pp. 275-276 (§ 8.6) and p. 778 (§ 19.5). For references to Rong Cheng shi and other sages in the Jinlouzi 金樓子 $\left(6^{\text {th }}\right.$ century) also focussed on the worthy rulers, see Khayutina 2020.

${ }^{7}$ Chen Ligui 陳麗桂 proposed a quantitative distribution of slips with respect to the described rulers: 3 slips refer to the sage rulers of remote antiquity, 2 slips to the events towards the end of remote antiquity preceding Yao, 8 slips to Yao, 4 slips to Shun, 17 slips to Yu, 9 slips to Cheng Tang, 6 slips to King Wen and 4-5 slips to King Wu, see Chen Ligui 2004, p. 336. Even if the attribution of some slips is debatable, these calculations give a general idea of the narrative's structure and show the substantial place of Yu's deeds in the manuscript.
} 
having multiple parallels with transmitted texts describing the same historical periods and events, the manuscript is distinguished by laying special emphasis on the "supremacy of power transfer through the ruler's abdication in favour of a worthier successor". 8

\subsection{Sequence of slips in the Rong Cheng shi manuscript: concurring reconstructions}

The investigation of the content of unearthed manuscripts on bamboo slips depends on solving two basic technical problems - the transcription of characters, and the restitution of the sequence of slips. Though there are relatively few variations in the transcriptions of the characters of the Rong Cheng shi manuscript, the sequence of its slips still remains a highly controversial issue, even though this work is considerably facilitated by the narrative chronology. Once the slips of a manuscript have been arranged into a more or less meaningful sequence, the focus of scholarly discussion tends to move on from such basic technical problems to the content and the context of the manuscript, unsolved techical issues fading into the background. ${ }^{9}$ Instead of the common method of choosing one sequence and then discussing the content, I propose to discuss the content of the slips while considering all their possible arrangements. I shall demonstrate that this approach may provide conclusive arguments for determining the most plausible place for some controversial slips. ${ }^{10}$

The first arrangement of the Rong Cheng shi slips and their transcription was proposed by Li Ling 李零 in the second volume of the Shanghai guji chubanshe edition of the corpus published in 2002. ${ }^{11}$ Since then the sequencing of slips and transcription of certain characters have been continuously challenged. ${ }^{12}$ Shortly after this publication, Chen Jian 陳劍 substantially changed Li Ling's sequence:

\section{[Chen Jian]}

\footnotetext{
${ }^{8}$ Pines 2010, p. 2; see also Pines 2005 and Allan 2015, pp. 181-184.

${ }^{9} \mathrm{Cf}$. the discussions of the state of the art of another manuscript from the Shanghai Museum Collection, the Kongzi Shilun 孔子詩論, in Staack 2010, p. 858. For a general discussion of reconstructing arrangement of bamboo slips, see Staack 2016.

${ }^{10}$ Staack has a stab at establishing a system of criteria for reconstructing the arrangement of bamboo slips comprising of all the available material and textual evidence, see Staack 2010, esp. pp. 857-881. The case of the Rong Cheng shi is somewhat more straightforward, as it is much better preserved, and my task is also simpler, as I discuss only a part of the manuscript.

${ }^{11}$ Ma Chengyuan, 馬承源, ed. 2002, pp. 91-146 [coloured photographs of numbered slips], pp. 247-293 [transcription and commentary by Li Ling 李零]. For an annotated version of Li Ling's sequence, see Qiu Dexiu 邱德修 2003.

${ }^{12}$ For reviews of relevant studies, see Pines 2005, p. 263, footnote 50; 2010, p. 3, footnote 6; Niu Xinfang 牛新房 2010, pp. 73-75 (§ 1); Sun Feiyan 孫飛燕 2010, pp. 13-14; Allan 2015, pp. 184-185, footnotes 4-5.
} 
$1-3,35 \mathrm{~B}, 4-7+43,9-11+13-14+8+12+23+15+24-30+16-21+31-32+22+33-34+35 \mathrm{~A}+38-41+36-37+42+44-53^{13}$

Chen Ligui 陳麗桂 ${ }^{14}$ and Bai Yulan 白於監 ${ }^{15}$ made further partial adjustments to the sequence, having restituted the succession of slips 21 and 22 proposed by Li Ling: ${ }^{16}$

[Chen Ligui]

[Bai Yulan]
$13-15+23-31+16-21-22+32-34$

$21-22+31+33-34+32+35 A$

The articles surveying Chinese scholarship on the Rong Cheng shi by Sun Feiyan 孫飛燕 and Niu Xinfang 牛新房 distinguish the following main suggestions about the slips' arrangements: ${ }^{17}$

1) Chen Jian noticed that two damaged fragments, considered by Li Ling to constitute slip 35, are in effect pieces of two different slips, now referred to as slip 35A and slip 35B. ${ }^{18}$

2) Dan Yuchen 單育辰 joins slips 15 and 24, arguing that these slips are pieces of one slip; ${ }^{19}$

3) Guo Yongbing 郭永秉 links slips 31 and 32 with slips 4 and 5; ${ }^{20}$

4) Guo Yongbing also proposes to insert slip 43, already advanced to the beginning of the text by Chen Jian, after slip $35 \mathrm{~A} .^{21}$

Niu Xinfang concludes his evaluation with a summarising rearrangement of slips, where he proposes to distinguish eight coherent groups: ${ }^{22}$

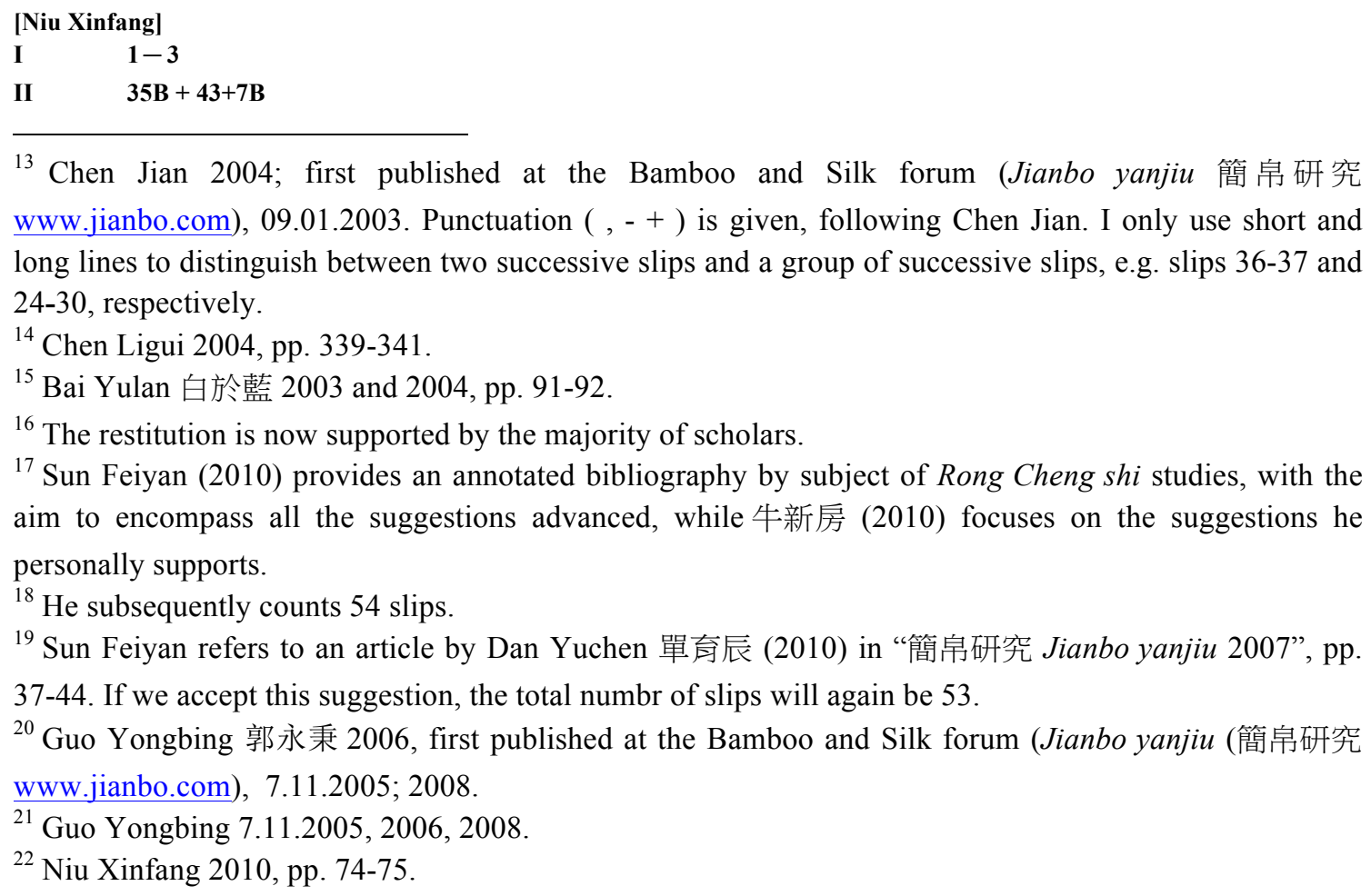




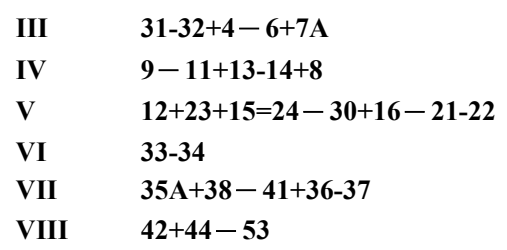

Yuri Pines, the author of the first English translation of the manuscript, follows Chen Jian's sequence, with the exception of reinstating the place of slip 22 after slip 21, but expresses strong doubts about Chen Jian's placement of slips 31 and 32 (I distinguish them by italics): ${ }^{23}$

[Chen Jian/Pines]

$1-3,35 \mathrm{~B}, 4-7+43,9-11+13-14+8+12+23+15+24-30+16-21-22+31-32+33-34+35 \mathrm{~A}+38-41+36-37+42+44-53$

Sarah Allan, who has provided a second translation of the manuscript with extensive commentary updated by recent studies, follows Guo Yongbing's sequence and the general consensus on reinstating Li Ling's sequence of slips 21-22; she also reinstates slips 36-37 before $38:^{24}$

[Guo Yongbing/Allan]

$1-3,35 \mathrm{~B}, 43,31-32,4-7,9-11,13-14,8,12,23,15,24-30,16-22,33-34,35 \mathrm{~A}, 36-42,44-53$

In sum, each scholar who has tried to deal with the sequence of slips in the Rong Cheng shi has come up with more or less different suggestions about their arrangement. There are groups of slips the order of which is shared by the majority of scholars. These groups can be recognised as definitive sets. There are at the same time some errant slips, the placement of which differs, sometimes rather considerably, among the suggestions advanced. $^{25}$

\subsection{The "cosmograph" pattern and putting waterways first in constructing space: reassessing slip 31}

One especially controversial slip - $\mathrm{N}^{\circ} 31$ - contains a "policy statement" for conceptualising terrestrial space in the Rong Cheng shi. It is preceded by a description of a cardinally-oriented twelve-fold pattern. Due to the conciseness of these references,

\footnotetext{
${ }^{23}$ Pines 2010, pp. 13-14. I shall discuss these two slips below.

${ }^{24}$ Allan 2015, chapter 6: pp. 181-222 (passage-by-passage interpretation); pp. 223-262 (translation supplied with comments on transcriptions and the identification of characters in current scholarship).

${ }^{25}$ To the usual difficulties of assembling a sequence from disordered elements, the early Chinese bamboo manuscripts add damaged and missing slips. Some slips are evidently missing from the beginning of the manuscript, but there might also be some missing from the body of the text, which further complicates the sequencing.
} 
neither the meaning of this spatial pattern, nor the significance of the "policy statement" have been fully appreciated in studies of this manuscript. Their profound implication emerges from an analysis within the broad context of early Chinese concepts of space derived from transmitted and manuscript texts. At the same time, the comparison of this passage with similar occurrences provides new arguments for determining the most plausible place of this slip in the Rong Cheng shi narrative.

\subsection{Placements and interpretations of slip 31}

Varying placements have been proposed for slip 31. Essentially there have been two approaches:

1) Li Ling, Chen Ligui, Bai Yulan and Chen Jian associate slip 31 with Yu, whose deeds are featured around the middle of the manuscript.

2) Guo Yongbing and Niu Xinfang place slip 31 at the beginning of the manuscript, considering it to be part of the description of an ancient sage ruler named Youyu Tong 有虞通, who is not found in transmitted texts. Guo Yongbing identifies characters 又吴迵 on slip 5 with 有虞通, and further reconstructs the same name in a group of faint graphs on slip 32, which is damaged.

It should also be noted that some scholars regard slip 31 as a pair to slip 32, others do not.

Yuri Pines in his translation follows the first approach, but expresses doubts about its belonging to the "Yu part" of the manuscript and the relation to slip 32. ${ }^{26}$ Sarah Allan's translation relies on Guo Yongbing's hypothesis about Youyu Tong and his placement of slip 31 at the beginning. ${ }^{27}$

The passage in question occupies almost the whole of slip 31. Sarah Allan claims that it advocates musical harmony: ${ }^{28}$

\begin{tabular}{|c|c|c|}
\hline \multicolumn{3}{|c|}{$\begin{array}{l}\text { [Rong Cheng shi, translation by Allan } \\
\text { slip 31, beginning from character } N^{\circ} 2 \text {; translation by Allan:] }\end{array}$} \\
\hline 始方爲三宮， & shi fang wei san gong, & He first made three tones, \\
\hline 救聲之紀: & jiu sheng zhi ji: & seeking a guide for the sounds (of a musical scale). \\
\hline 東方爲三宮， & dong fang wei san gong, & He made three tones for the East, \\
\hline 西方爲 三宮, & xi fang wei san gong, & three tones for the West, \\
\hline 南方爲三宮， & nan fang wei san gong, & three tones for the South, \\
\hline 北方爲三宮, & bei fang wei san gong, & three tones for the North, \\
\hline
\end{tabular}

\footnotetext{
${ }^{26}$ Pines 2010, p. 14, footnote 34.

${ }^{27}$ Allan 2015, p. 192, footnote 15.

${ }^{28}$ Allan 2015, pp. 192-195 and 228-231.
} 


\begin{tabular}{|c|c|c|}
\hline 以㦣於溪浴 (= 谷), & yi wei (yue) yu xi yu, & using [the sounds of] crossing brooks and streams \\
\hline 濟於廣川, & ji yu guang chuan, & and fording wide rivers, \\
\hline 高山债， & gao shan sheng & of mountains high up [and] \\
\hline 蓁林 & zhen lin & dense forests \\
\hline $\begin{array}{l}\text { [end slip 31] } \\
\text { [slip 32, 1st character:] }\end{array}$ & & \\
\hline 入。 & $r u$. & deep in. \\
\hline
\end{tabular}

Allan focuses her attention on the musical scale, which may be implied in the phrase jiu sheng zhi ji 救聲之紀. Allan translates it as "seeking a guide for the sounds (of a musical scale)" and identifies the character gao 俈 with gong 宮 (“tone"). In this case the total of twelve gao corresponds to the twelve-pitch scale 十二律 shi'er lü used in ancient Chinese music.

Allan (Li Ling, Chen Jian and Guo Yongbing) begins the passage with the second character on slip 31, which she reads, having accepted one among its identifications, as shi 始, and ends it with the first character on slip 32, which is generally transcribed as $r u$ 入 ("to enter, to penetrate"). $R u$ used as a predicate with forests makes a good match with sheng 陡 ("to mount, to ascend") used as a predicate with mountains - gao shan sheng, zhen lin $r u$ 高山债, 䔉林入 ("high mountains became ascendable, dense forests penetrable"). One issue with this reading is the fact that after $r u$ 入 follows yan 焉 (= yu zhi 於之). The combination of these two characters is quite common in early Chinese texts. It means "to enter somewhere" and as a rule is found at the end of a phrase. Ru yan at the beginning of slip 32 looks more likely to be the ending of another passage, so some scholars, for instance, Bai Yulan and Chen Ligui separate slips 31 and 32 .

Although Yuri Pines in his translation of the Rong Cheng shi accepts a successive arrangement of slips 31 and 32, he tries to solve the problem of their mismatch by calling attention to the damaged nature of slip 32, suggesting that some neighbouring slips might be missing. He translates the beginning of slip 32 as the end of a lost piece of text: ru yan, yi xing zheng 入焉, 以行政 “[he] entered there to perform administrative tasks". Pines also feels that no satisfactory identifications of the character gao have been made and cautiously translates it as some type of ritual.$^{29} \mathrm{He}$ gives credit to the musical aspect, but does not exaggerate it, and better fits the transmitted written tradition in translating the context: ${ }^{30}$

[Rong Cheng shi, translation by Pines;

slip 31, beginning from character $\left.N^{\circ} 3:\right]$

\footnotetext{
${ }^{29}$ See Pines 2010, p. 14, footnote 35.

${ }^{30}$ Pines begins the passage with the third character on slip 31, and considers the second character to be $j u n$ 君 (and not shi 始 accepted by Allan).
} 


\begin{tabular}{|c|c|c|}
\hline \multicolumn{3}{|c|}{ At every direction he performed gao ceremonies (?), ${ }^{31}$} \\
\hline 救聲之紀: & qiu sheng zhi ji: & to obtain the essentials of the sounds (?): \\
\hline 東方爲三俈, & dong fang wei san gao, & three gao to the east, \\
\hline 西方爲 三俈， & xi fang wei san gao, & three gao to the west, \\
\hline 南方爲三俈， & nan fang wei san gao, & three gao to the south, \\
\hline 北方爲三俈， & bei fang wei san gao, & three gao to the north: \\
\hline 以㦣 $(=$ 越)於溪浴(=谷), & yi wei (yue) yu xi yu, & thereby he traversed creeks and gorges, \\
\hline 濟於廣川, & ji yu guang chuan, & crossed broad rivers, \\
\hline 高山㙫, & gao shan sheng, & ascended high mountains, \\
\hline & zhen lin & $\square$ dense forests. \\
\hline
\end{tabular}

I give preference, with some minor amendments of my own, to Pines' interpretation of the passage:

[Rong Cheng shi, translation by the author of this article, slip 31, beginning from character $\mathrm{N}^{\circ}$ 3:]

方爲三俈， fang wei san gao, At/to every cardinal direction [he] performed three gao ceremonies, 救聲之紀: qiu sheng zhi ji: $\quad$ seeking the proper order of the sounds:

東方爲三俈， dongfang wei san gao, in/to the East performed three gao ceremonies, 西方爲 三俈， xi fang wei san gao, in/to the West performed three gao ceremonies, 南方爲三俈， nan fang wei san gao, in/to the South performed three gao ceremonies, 北方爲三俈， bei fang wei san gao, in/to the North performed three gao ceremonies. 以徫(=越)於溪浴(=谷), yi wei (yue) yu xi yu, This enabled [him] to traverse brooks and river-valleys; 濟於廣川, ～ji yu guang chuan, cross broad rivers, 高山㙫， gao shan sheng, gigh mountains became ascendable, 䔉林... zhen lin dense forests....

[end of slip 31]

\subsection{A twelve-to-four pattern for tailoring space}

According to both interpretations, this passage first of all describes structuring space into twelve cardinally-oriented units - three at each of the four cardinal directions. This spatial structure underlies all the other possible correlations, including the twelve-pitch scale. At the same time, the character $j i$ 紀, designating here the order of sounds, in contemporary transmitted texts is systematically used in relation to duodecimal temporal cycles, in particular the system of twelve months of the year, the "Shi'er ji” 十二紀 (“Twelve Monthly Records”) section of the Lüshi chunqiu 呂氏春秋 (“Springs and Autumns of Mister Lü”, compiled shortly before 239 BC) and its counterpart, the "Yue ling”月令 ("Monthly Ordonances", ca. $2^{\text {nd }}$ century BC) chapter of the $L i$ ji 禮記 ("Records of Ritual", compiled about the $1^{\text {st }}$ century AD), being the loci classici for the duodecimal

\footnotetext{
${ }^{31}$ Taking fang 方 as a noun in relation to the subsequent focus on the cardinal arrangement makes much more sense.
} 
calendar texts. ${ }^{32}$ The twelve months arranged into four seasons correlated with the four cardinal directions constitute the Chinese cosmographical conception of space-time, which is in the first place evoked by the twelve-to-four pattern. Figure 1 shows the spatio-temporal deployment of the twelve months with a correlated cardinally-oriented arrangement of twelve gao.

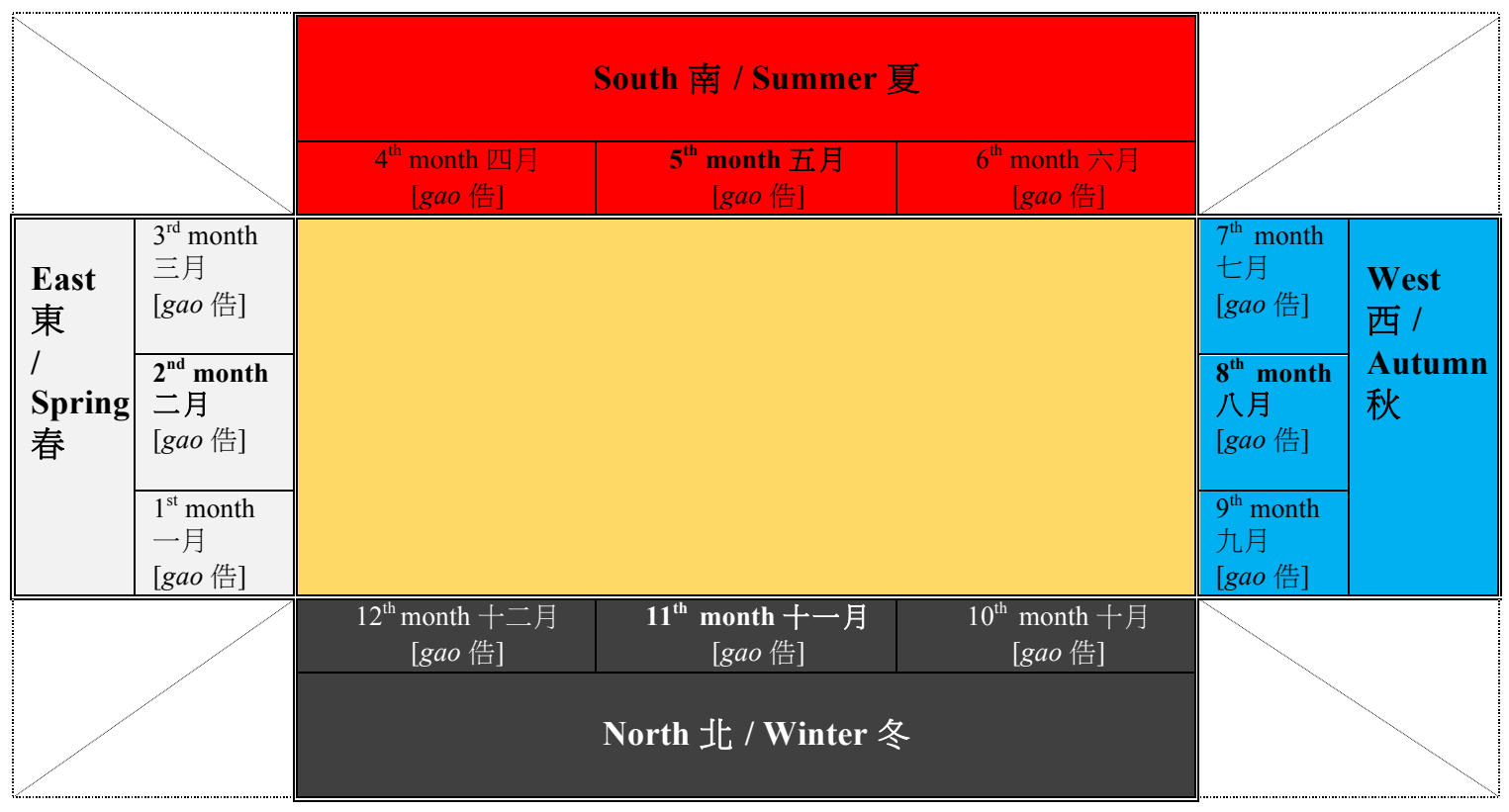

Figure 1. 12 months of the year arranged into 4 seasons correlated with the 4 cardinal directions with superimposed 12 gao 俈

One could argue that the scheme above is a reconstruction and that there are other possible ways to array the twelve months of the year. However, their pictorial representation, according to the pattern above, is found in another manuscript of $\mathrm{Chu}$ provenance roughly contemporary with the Lüshi chunqiu and the Rong Cheng shi, the so-called Chu Silk Manuscript, recently re-labelled as Chu Silk Manuscript no.1 (ca.

32 For the “Shi'er ji”, Section I of the Lüshi chunqiu, see Lüshi chunqiu 呂氏春秋 (Sibu beiyao ed.), 1.1a - 12.10b; for translations of this section that put in evidence the twelve-to-four pattern emulated by its textual structure, cf. Wilhelm, trans., 1928, pp. 1-156; Kamenarovic, trans., 1998, pp. 29-189; Knoblock and Riegel, trans. 2000, pp. 59-273; Tkachenko, trans., 2001, pp. 71-181; for a summary on the "Shi'er ji” structure, see Tkatchiénko, 1991; for the “Yue ling” chapter of the Li ji, see Liji Zheng zhu禮記鄭注 (Sibu beiyao ed.), 5.1a-29b; for translations of this chapter that put in evidence the twelve-to-four pattern emulated by its textual structure, cf. Legge, trans., vol. 27, 1885, pp. 229-310; Couvreur, trans., vol. 1, 1913, pp. 330-410. 
$47 \times 38.7 \mathrm{~cm}$ in its present condition, estimated original size $48 \times 40 \mathrm{~cm} ;{ }^{33}$ ca. late 4 th century BC, unearthed by grave robbers sometime between 1934 and 1942 at Zidanku 子 彈庫, Changsha, Hubei province). This has been studied intensively since the middle of the $20^{\text {th }}$ century. Among milestone studies are those by Li Ling, who not only takes notice of its peculiar spatio-temporal layout, which combines textual passages and pictures, but also calls attention to its meaning and a functional significance. ${ }^{34}$ Having first explored various shapes of the shitu 式圖, which he translates as "a diagram of shi 式 (or cosmic model)", ${ }^{35}$ Li Ling establishes the link between the layout of Chu Silk Manuscript no.1 and cosmological devices shipan 式/栻盤, commonly referred to as divining or cosmic boards or cosmographs. The divining or cosmic board or "cosmograph" has a square base plate with a rotating disc on top, representing Earth and Heavens, respectively. ${ }^{36} \mathrm{He}$ supports his point of view with two diagrams, which demonstrate their parallels. The first diagram shows the arrangement of the manuscript's textual units supplied with indications to the reading direction of each unit and their tentative sequence - clockwise from the centre to periphery. This requires the rotation of the manuscript by its "user" and makes the diagram a process-oriented scheme (Figure 2a). ${ }^{37}$ This diagram highlights the non-

\footnotetext{
${ }^{33}$ Li Ling 2013, p. 181 and 217.

${ }^{34}$ Insights into these aspects made in Li Ling's first monograph on Chu Silk Manuscript no.1 (Li Ling 1985) were then developed in a special article (Li Ling 1991), and further in the context of fangshu 方術 practices (Li Ling 2000 [rev. 1993], pp. 89-231). The manuscript was recently reassessed by Li Ling in two monographs (Li Ling 2013 and 2017). The 2013 book is a convenient collection of Li Ling's studies on Chu Silk Manuscript no.1, including a translation, glossary and several articles, some in Chinese and English versions, discussing the similarity between Chu Silk Manuscript no.1 and the "diagram of shi 式 (or cosmic model)" from different angles (Li Ling 2013, pp. 1-74, pp. 155-243, pp. 252-287). He also makes observations on the context of the discovery and material aspects of the manuscript, as well as the other silk manuscripts found together with it, unfortunately considerably damaged (Li Ling 2013, pp. 171-243). These are the focus of his most recent study (Li Ling 2017). The first volume (see also its English version translated by von Falkenhausen, Li Ling 2020) is devoted to the history of the discovery and scholarly transmission of these manuscripts. The second is focussed on reconstructions and philological analysis of the manuscripts and fragments; for Chu Silk Manuscript no.1 labeled 四時令 Sishi ling, see Li Ling 2017, vol. 2, pp. 43-77, for Chu Silk Manuscript no.2 labeled 五行令 Wuxingling and other fragments, see Li Ling 2017, vol. 2, pp. 78-113.

${ }^{35}$ Li Ling 2013, p. 155

${ }^{36}$ Such devices are discussed in two recent monograph studies of early Chinese cosmography and cosmology: Pankenier 2013, who refers to these devices throughout his book as a "mantic astrolabe", and Cullen 2017, Chapter 5 "The Measures and Forms of Heaven," pp. 179 - 222, especially pp. 202-207 and fig. 5.7 on p. 203, and in an article by Huang Ru-Xuan 黃儒宣 (2019), which discusses a series of "cosmograph"-related depictions, including manuscripts on silk from the Mawandui. For a list of earlier studies of "cosmographs", see Dorofeeva-Lichtmann 2007, p. 249 (footnote 79). The earliest excavated copies of "cosmographs" date from the Western Han dynasty.

${ }^{37}$ See Li Ling 1985, pp. 30-31; 2013, p. 29 (small diagram with no title). Even if one accepts a different reading sequence, it would still require a rotation. In Li Ling 2000 [rev. 1993], p. 111 (fig. 21), the scheme is provided at a larger scale and with a title - 楚帛楚的圖式 Chuboshu de tushi “Scheme of the Chu Silk
} 
linear textual structure of the manuscript, especially valuable due to its being the original, not reconstructed textual arrangement. ${ }^{38}$ The second diagram shows the pictorial images in a square pattern, that is, the twelve monthly divinities, three on each side of the manuscript, with four trees placed in the corners (Figure $\mathbf{2 b}$ ). ${ }^{39}$ The same pattern is found on the square bottom (=Earth) plate of the so-called Liuren 六王 type of a cosmograph, on which the twelve cyclic signs (Earth branches) are arranged within the second square zone from the outside (Figure 2c).

Summer-South
Summer-South

Manuscript", but regretfully does not provide indications to the reading direction and the sequence of passages.

${ }^{38}$ Although non-linear texts per se are not the focus of Li Ling's interests, from the very beginning of his studies of Chu Silk Manuscript no.1 he pointed out this attribute of the manuscript and its typological similarity with reconstructions of the "You guan" 幼官 chapter of the philosophical treatise Guanzi 管子 (compiled about the end of the $1^{\text {st }}$ century BC) in the shape of a cardinally-oriented ground "plan of the Dark Palace" (玄宮圖 Xuangong $t u$ ), as well as with the textual structure of the Shanhai jing 山海經 ("Itinearies of Mountains and Seas", compiled about the $1^{\text {st }}$ century BC), see Li Ling 1985, pp. 39-44; 2000 [rev. 1993], pp. 135-140; 2013, pp. 37-40, 123-125. The first reconstruction of the Dark Palace plan, which was ground-breaking for considering non-linear textual structures, was proposed by Guo Moruo 郭 沫若 and Wen Yiduo 聞一多 in 1956. I discuss spatially organised early Chinese texts as a type of textual structure and their studies in Dorofeeva-Lichtmann 2004, and the structure of the Shanhai jing in relation to Chu Silk Manuscript no.1 in Dorofeeva-Lichtmann 2007 (for Chu Silk Manuscript no.1, see pp. 242249). Studies of various non-linear textual structures not necessarily dealing with space were mainstream in Soviet studies of early China in the 1970s through the late 1990s. For a survey and some translations, see Chemla, Volkov and Lichtmann 1991; see also more recent surveys by Rykov 2016 and Grebnev 2020. Argumentation by means of textual diagrams in neo-Confucian scholarship, many diagrams referring to early texts, is extensively discussed by Michael Lackner, and for an overview, see Bray 2007, esp. 5-40. There has been a rise in interest in non-linear textual studies in Western sinology from the mid 2000s, see, for instance, the latest collection of articles edited by Gentz and Meyer 2015. Regretfully, the editors, while apparently relying on previous scholarship in the field, do not give full credit to it.

${ }^{39}$ Li Ling 2000 [rev. 1993], p. 180 (fig. 27). Reproduced several times under the title 楚帛書的圖像[安排] Chuboshu de tuxiang [anpai] and translated for the English version as "The twelve gods representing the months of the year", in Li Ling, 188 (fig. 15), 224 (fig. 9), 273 (fig. 1).. 


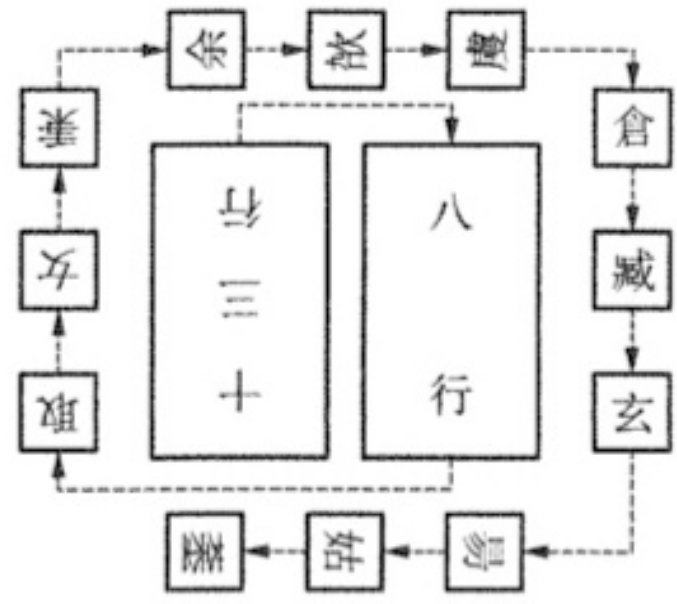

Winter-North

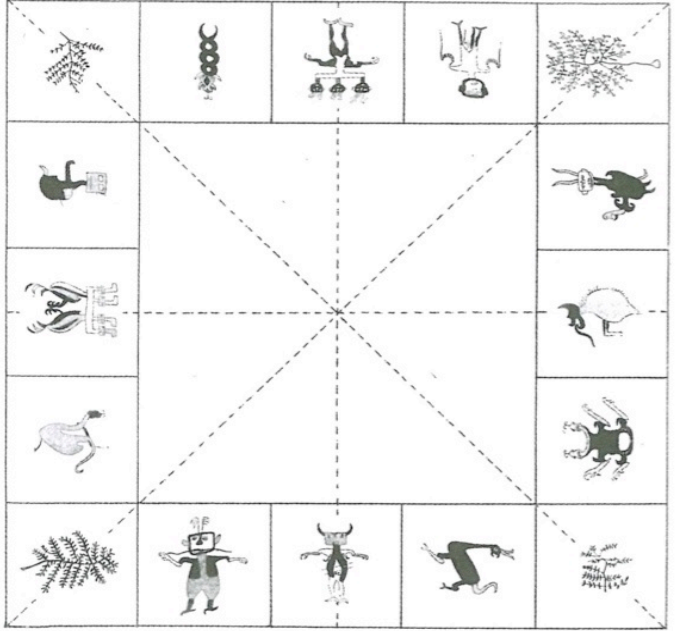

Winter-North

Figure 2a

Figure 2b

\begin{abstract}
Figure 2a (left)
General arrangement of Chu Silk Manuscript no. 1 and its tentative reading sequence

[Reproduced from Li Ling 2013, p. 29, re-oriented with the South on top; estimated size of the original diagram ca. $40 \times 40 \mathrm{~cm}$ ] Centre: two long textual passages written inversely with respect to each other, one comprised of thirteen and the other of eight columns.

Margins: twelve short textual passages related to the monthly divinities, the names of which are placed in the reading direction of the respective passage.

\section{Figure 2b (right)}

Cosmograph-like square pattern marked by the twelve monthly divinities and four corner trees in Chu Silk Manuscript no.1 [Reproduced from Li Ling 1993, p. 170, fig. 47; estimated size of the original diagram ca. 40x40]

A group of three divinities at each side of the manuscript corresponds to a season.

Cardinal orientation is not noted explicitely, but may be reliably derived from its correlation with the seasons.
\end{abstract}


Summer-South

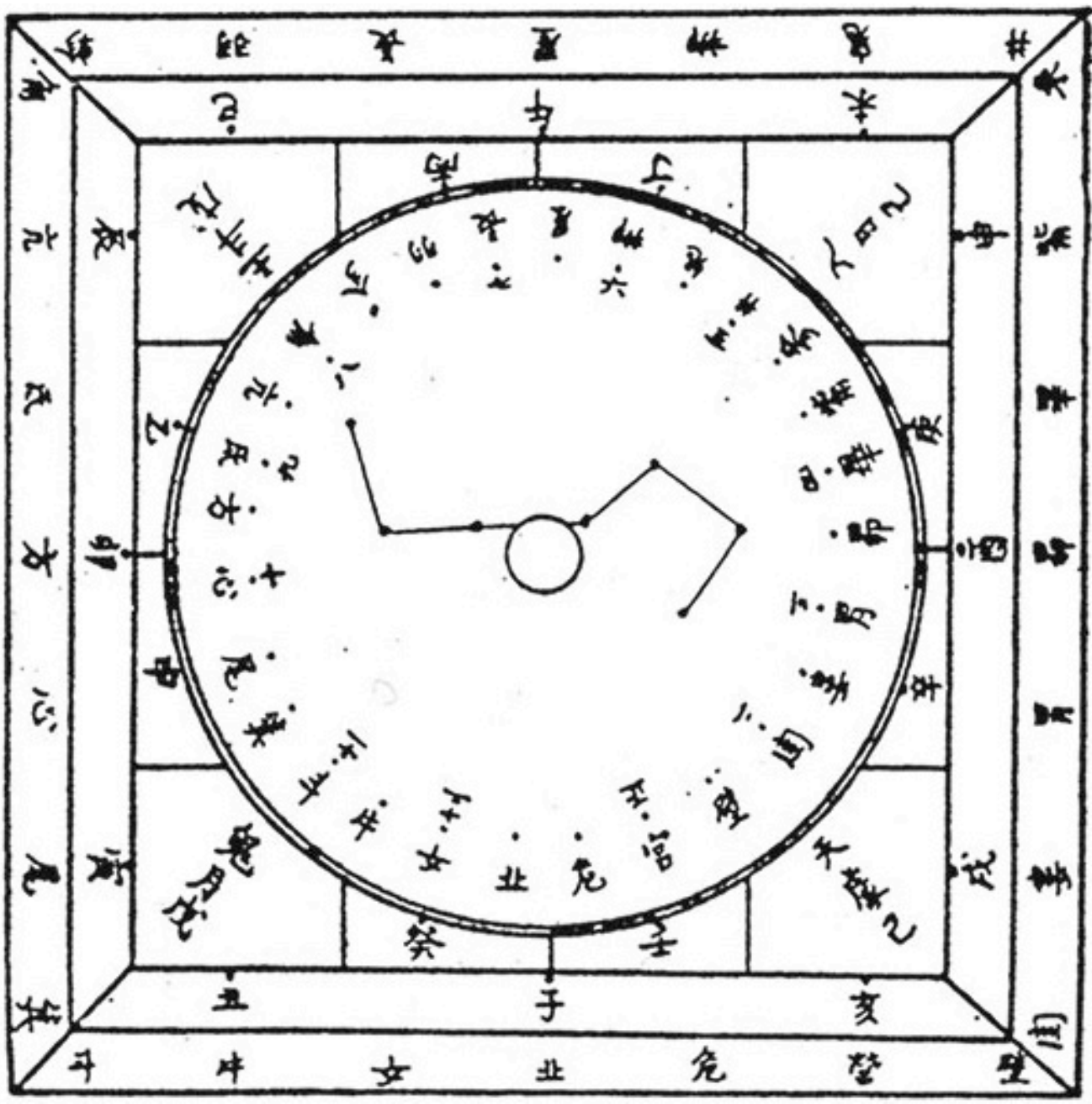

Winter-North

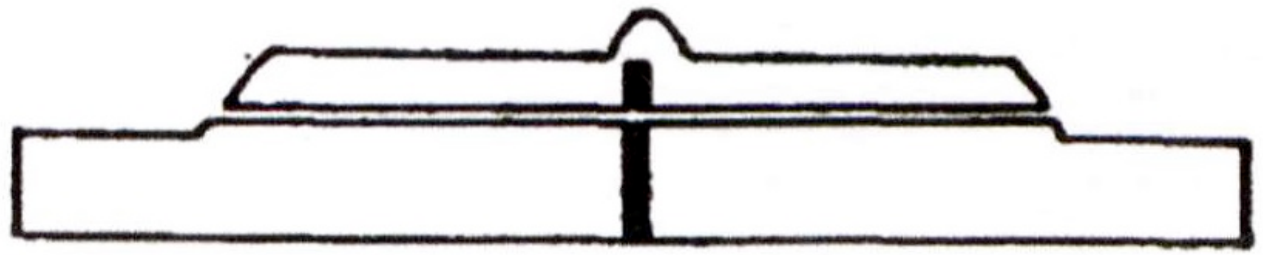

Figure 2c

\section{Figure 2c}

The so-called Liuren 六王 type of the divining or cosmic board or “cosmograph"

from the tomb of Marquis of Ruyin 汝陰侯 closed in 165 BC, Shuanggudui 雙古堆, Fuyang 阜陽 ;

[Redrawing with cross-section below, laquered wood, bottom plate: $13,5 \mathrm{~cm}$, upper disc diameter: $9,5 \mathrm{~cm}$.

reproduced from Yin Difei 陰涤非 1978, p. 340, fig. 1; for a slightly different redrawing, see Anhui sheng wenwu gongzuodui

安徽省文物工作隊 1978, p. 25, fig. 10]. 
Chu Silk Manuscript no.1 was accompanied by at least one text, which contains a diagram with a circular arrangement of months. The diagram is considerably damaged, but its colours and shape can still be ascertained from the surviving pieces - two concentric circles, both delineated in black and red, each with regular arrangements of the twelve months, see in Figure 2d (extant state) and Figure 2e (reconstruction). ${ }^{40}$ The circular diagram has affinity with the "cosmograph's" heavenly disc and with the device composed of two discs conventionally referred to as a "lodge dial" found together with the Liuren "cosmograph" (see Figure 2f). ${ }^{41}$

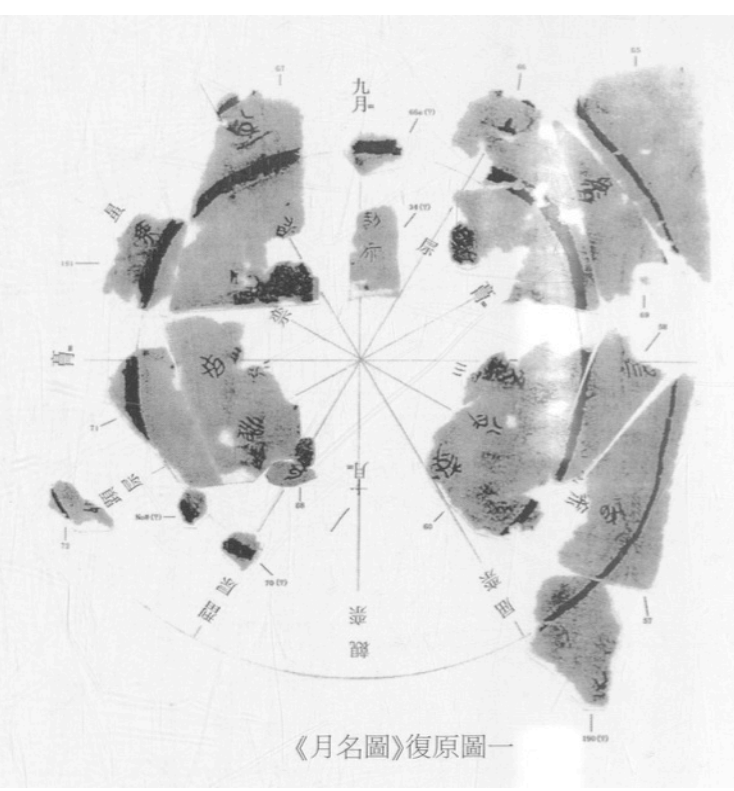

Figure 2d

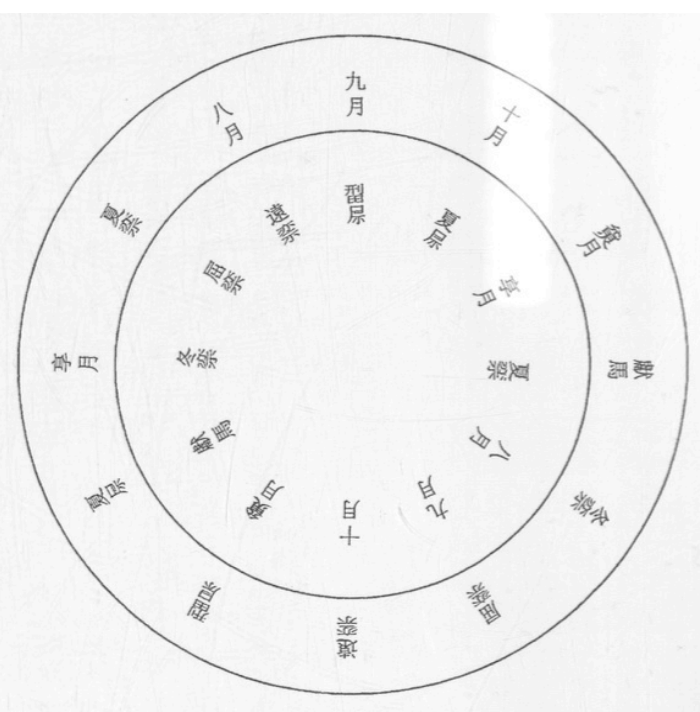

《月名圖》復原圖二

Figure 2e

\section{Figure 2d}

Diagram with two circular arrangements of the twelve months, extant state

[Delineated in red and black, reproduced from Li Ling 2017, p. 79, fig. 1]

Figure 2e

Diagram with two circular arrangements of the twelve months, reconstruction

[Reproduced from Li Ling 2017, p. 79, fig. 2]

\footnotetext{
${ }^{40}$ Li Ling 2017, vol. 2, pp. 10-11 (colour plates), reconstruction and interpretation pp. 78-81, the diagram labelled by Li Ling “The Diagram of Month's Names” Yuming $t u$ 月名圖 belongs to the text, which he refers to as the 五行令 Wuxing ling.

${ }^{41}$ Cullen 2017, pp. 205-206.
} 


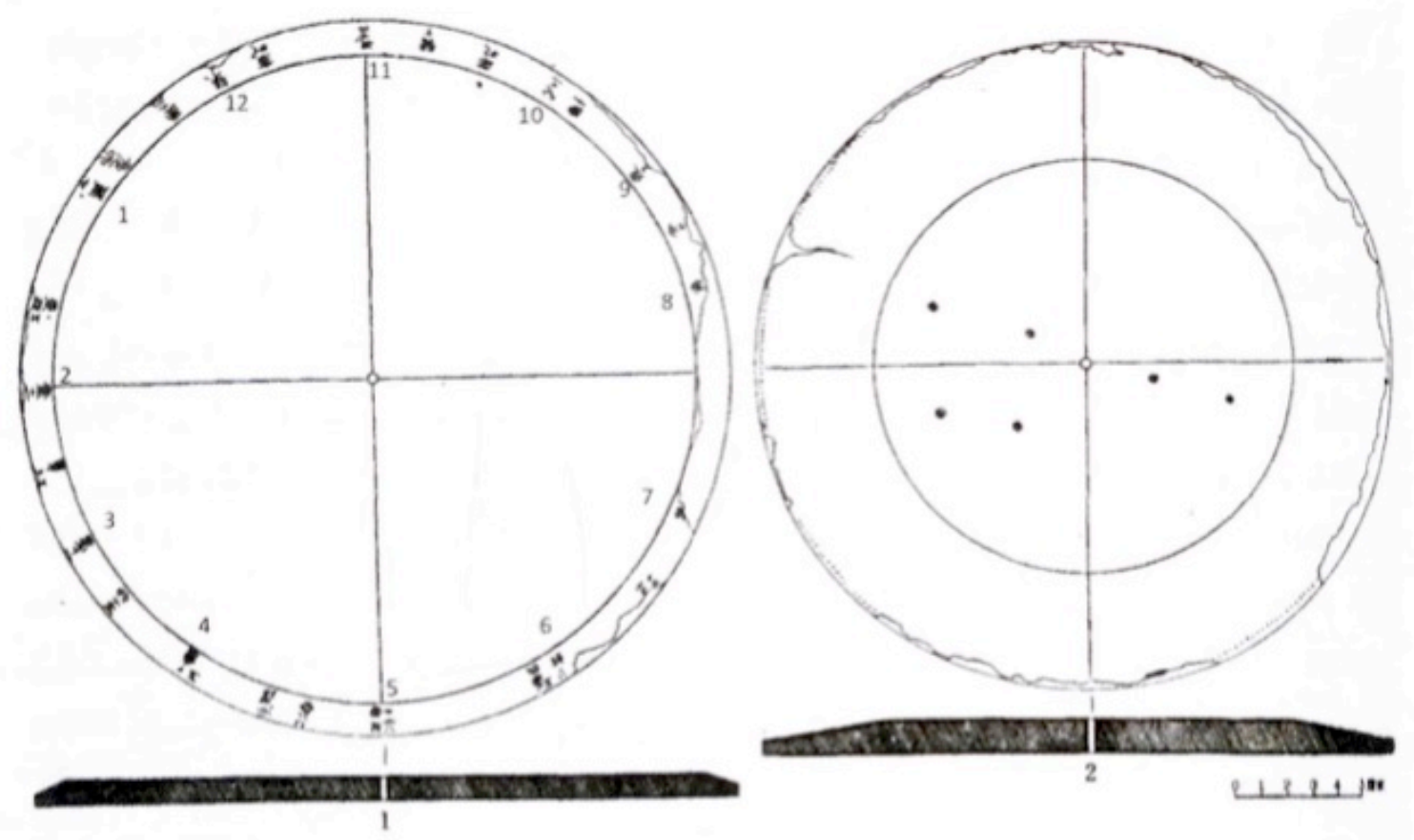

Figure 2f

Figure 2f

The “lodge dial” device from the tomb of Marquis of Ruyin 汝陰侯 closed in 165 B.C.E, Shuanggudui 雙古堆, Fuyang 阜陽

[Redrawing with cross-section below, laquered wood, bottom disc diameter: $25,5 \mathrm{~cm}$, upper disc diameter: $23 \mathrm{~cm}$.

reproduced from Anhui sheng wenwu gongzuodui 安徽省文物工作隊 1978, p. 19, fig. 8; for a slightly different redrawing see Yin Difei 陰涤非 1978, p. 342, fig. 3].

The circular diagram in Chu Silk Manuscript no.2, which has become available to the scholarly community only recently, offers an important argument in favour of typological parallels of Chu Silk Manuscript no.1 with a "cosmograph". The two manuscripts constitute a pair as both convey schematic arrangements of the twelve months: their arrangement according to the square twelve-to-four pattern in Chu Silk Manuscript no.1 was complemented by their circular arrangement in Chu Silk Manuscript no.2. The two manuscripts are, therefore, related as with the earthly and the heavenly plates of a "cosmograph".

The importance of Chu Silk Manuscript no.1 for understanding the system of twelve gao in the Rong Cheng shi is not limited to structural parallels between the arrangement of the twelve monthly divinities in the former and the deployment of gao in the latter. Their pictorial content - symbolyzing months by their divinities - points to a highly important role of divinities in the early Chinese conception of space, coordinated with the yearly cycle of seasons and months. ${ }^{42}$ Yet this text, as well as being a

\footnotetext{
${ }^{42}$ I discuss the role of divinities in ordering terrestrial space in early China in Dorofeeva-Lichtmann 2003a, 2003b, and 2007, on the example of the Shanhai jing in relation to the Chu Silk Manuscript no.1.
} 
"cosmograph", provides a diagram or device imbued with some intrinsic techniques for process-oriented use - rotation, though they do not describe the process proper. Indeed, the process of managing this space-time accomplished through sacrifices to divinities in charge of units of the spatio-temporal division perfectly qualifies Emperor Shun's "tour of inspection” xun shou 巡狩, as described in a transmitted source roughly contemporary with the Rong Cheng shi, the “Shun dian” 舜典 [Karlgren: “Yao dian 2" 堯典續] chapter of the Shang shu 尚書. ${ }^{43}$ This description is a case of verbal mapping devoid of graphical illustrations, as is the description of the twelve gao. The juxtaposition of such verbal schemes or relevant texts with authentic visual aids, for some reason often missing in extant scholarly approaches, allows one to establish the missing links between scheme and action necessary for undersanding both.

Without going into the details of the various sacrifices, the "tour of inspection" may be summarized as follows:

In the $2^{\text {nd }}$ month of the year (sui eryue 歲二月 = mid-Spring) the "tour of inspection" goes

in the Eastern direction towards the Taizong 岱宗 (= Eastern Peak) for performing a series of rites;

In the $5^{\text {th }}$ month (wuyue 五月 = mid-Summer) the "tour of inspection" goes

in the Southern direction towards the Southen Peak for performing the same series of rites;

In the $8^{\text {th }}$ month (bayue 八月 = mid-Autumn) the "tour of inspection" goes

in the Western direction towards the Western Peak for performing the same series of rites;

In the $11^{\text {th }}$ month (shiyiyue 十一月 $=$ mid-Winter) the "tour of inspection" goes

in the Northern direction towards the Northern Peak for performing the same series of rites.

One can see that the "tour of inspection" is accomplished according to the twelveto-four pattern mapped out by the Chu Silk Manuscript no.1. The "tour of inspection" can therefore be devined as a seasonal succession of rites, performed at the corresponding cardinal directions. The "tour" starts in Spring in the East and proceeds clockwise to the South in Summer, then to the West in Autumn and finally to the North in Winter, thus accomplishing a complete yearly cycle encompassing the entire terrestrial space. The

\footnotetext{
${ }^{43}$ I discuss the implications of this passage in Dorofeeva-Lichtmann 2019 [rev. 2009], pp. 638-640. For the complete passage and its three main scholarly translations that differ and at the same time complement each other, see Shangshu zhengyi, Sibu beiyao ed., 3/3a-6b; Legge, trans. 1865, pp.33-37 (§ 6-9); Couvreur 1897, pp. 15-19 ( $\S 6-9)$; Karlgren, trans. 1950, pp. 2 and 4, $\S \S 17-20$. Legge's and Couvreur's translations have extensive, but not always similar commentaries. Karlgren's "The Book of Documents" is preceded by separate glosses $(1948,1949)$. It assembles only the "New Script" chapters of the "Book of Documents" (Shu jing), having rearranged some of them, namely, the "Shun dian", which corresponds to the $2^{\text {nd }}$ part of the "Yao dian" chapter. For a general discussion of the "Yao dian" chapter in the modernscript recension, including the complexity of its dating, see Kern 2017, and also Vogelsang 2017, pp. 7889. Both articles are parts of a recent volume devoted to the Shang shu, see Kern and Meyer, eds. 2017, reviewed by Schaughnessy 2018. The passage is cited in the "Wang zhi" 王制 chapter of the Li ji, see Liji Zheng zhu (Sibu beiyao ed.), 4/5a-6a; Legge 1885, vol. 27, pp. 216-217 (II, § 13-16); Couvreur 1913, vol. 1, pp. 275-278 (II, § 13-16), discussed below.
} 
space-regulating rites are performed in the middle month of each season at the true cardinal points marked by the four Peaks (yue 岳). ${ }^{44}$

"Performing gao" (wei gao 為俈) described in the Rong Cheng shi also starts in the East, but proceeds crosswise - first from East to the West, then from the South to the North. Temporal correspondences are not in evidence in "performing gao", as it regulates terrestrial space through delineating its crosswise/horizontal and longwise/vertical axes, unrelated to the seasonal sequence. Similarly to the arrangement of the monthly divinities in the Chu Silk Manuscript no.1, the cardinally-oriented threesomes of gao does not put any special emphasis on the central gao among the three at each cardinal direction.

Despite these structural variations, "performing gao" and the "tour of inspection" describe actions aimed at establishing a regular framework of terrestrial space, both being typologically similar process-oriented schemes. This is a strong argument in favour of understanding wei gao as the performance of certain space-regulating ceremonies. The ceremonies may have a musical aspect, but their main goal is spatial arrangement. ${ }^{45}$

\subsection{From mountains to waters or vice versa?}

An even stronger argument in favour of the primary spatial significance of the twelve gao is the similar outcome of "performing gao" and the "tour of inspection" - to establish manageable elements of terrestrial space. Shun's "tour of inspection" results in the initiation of "provinces" as units of territorial division, twelve in total, followed by the establishment of a matching number of key mountains and making rivers deeper, the latter unnumbered. The repeated emphasis on the number twelve correlates with the twelve-tofour pattern underlying the "tour of inspection": ${ }^{46}$

[Shang shu, "Shun dian”, Karlgren "Yao dian 2", § 21:]

肇十有二州, 封十有二山, 濬川. Zhao shiyouer zhou, fu shiyouer shan, dian chuan

[Shun] founded the "Twelve provinces", assigned twelve mountains [and] deepened rivers.

\footnotetext{
${ }^{44}$ An elaborate month-by-month description of the yearly ritual cycle, starting from the first month of spring, constitutes the "Shier ji" section of the Lüshi chunqiu and the "Yue ling" chapter of the Li ji, referred to above.

${ }^{45}$ In particular, during his "tour of inspection" Shun "unified pitches, degrees, volumes and weights" (tong lü du liang heng 同律度量衡), but these actions are part of arranging space, and not the main goal. Though a relation between the twelve gao 俈 and a twelve-pitch scale is highly plausible, the interpretation of landscape features in terms of their sounds, as proposed by Allan in her translation of slip 31 , does not have any grounds for support in the manuscript or transmitted texts.

${ }^{46}$ Shangshu zhengyi, Sibu beiyao ed., 3/8b; Legge, trans. 1865, pp. 38 (§ 10); Couvreur 1897, p. 20 (§ 10), Karlgren, trans. 1950, pp. 5-6, $\S 21$. References to the Shang shu hereafter follow its convenient division into chapters and paragraphs by Bernhard Karlgren; translations of the Shang shu provided hereafter are my own; they take into consideration the three main scholarly translations that differ between each other and include my own emmendations.
} 
The outcome of Shun's "tour of inspection", in turn, is further paraphrased in the introduction to the establishment of the "Nine Provinces" (Jiu zhou 九州, literally "Nine Isle-lands") by his subordinate and then successor, Yu the Great 大禹), as described in the “Yu gong” 禹貢 (“Yu's [system] of Tribute”) chapter of the Shang shu: ${ }^{47}$

[Shang shu, "Yu gong”, Karlgren, § 1:]

禹敷土, 隨山刊木, 奠高山大川. Yu fu tu, sui shan kan mu, dian gao shan da chuan

$\mathrm{Yu}$ laid out the lands; moved along the mountains [as orientation marks and]

cut down trees (or made cuts [as signs] on trees)

[in order to blaze itineraries through forested highlands],

settled the high mountains [and] the big rivers.

According to these summaries, both Shun and Yu first put in order mountains and then rivers. A detailed arrangement of terrestrial space in this particular sequence is developed further in the "Yu gong", in the description of the ways of communication Yu paved through the "Nine Provinces": first nine land itineraries marked by mountains, then nine river itineraries. ${ }^{48}$

Another summary of Yu's regulations included into the "Yi [and Hou] Ji" 益 稷 (Karlgren: "Gao Yao mo 2") chapter of the Shang shu contains the same phrase about mountains found in the introduction to the description of the "Nine Provinces" in the "Yu gong", but is distinguished by paying special attention to regulating waterways: ${ }^{49}$

[Shang shu, "Yi [and Hou] Ji”, Karlgren: “Gao Yao mo 2”, § 9:]

予乘四載, 隨山刊木... Yu cheng si zai, sui shan kan mu...

予決九川, 距四海; Yu jue jiu chuan, ju si hai,

濬畎澮, 距川. Dian quan kuai, ju chuan.

I (= Yu) having mounted my four (kinds of) conveyances, moved along the mountains [as orientation marks and] cut down trees (or made cuts [as signs] on trees)

[in order to blaze itineraries through forested highlands].

$\mathrm{I}(=\mathrm{Yu})$ released the flows of the nine [main] rivers and led [them] into the seas of the four [cardinal directions], deepened field-drains and [drainage] ducts and led [them] into the [main] rivers.

\footnotetext{
${ }^{47}$ Shangshu zhengyi, Sibu beiyao ed., 6/1a-b; Legge, trans. 1865, pp. $92-93$ (§ 1); Couvreur, trans. 1897, pp. 61-62 (§ 1); Karlgren, trans. 1950, pp. 12-13, §1.

${ }^{48}$ Dorofeeva-Lichtmann 2019 [rev. 2009], pp. 627-629.

${ }^{49}$ Shangshu zhengyi, Sibu beiyao ed., 5/1a-b; Legge, trans. 1865, pp. 77-78 (§ 1); Couvreur, trans. 1897, pp. 49-50 (§ 1); Karlgren, trans. 1950, pp. 9-10, § 9, but is not identical to any of them. The resulting translation is to a considerable extent inspired by the interpretation of this passage by Artemy M. Karapetiants during his classical Chinese lessons I was privileged to attend during my university and postgraduate studies (1980-1985). For a recent general discussion of "Gao Yao mo" chapter in the modern script recension, see Vogelsang 2017, pp. 63-78.
} 
In contrast to the simple "deepening" of rivers by Shun and by $\mathrm{Yu}$ in the introduction to the "Nine Provinces", the passage from the "Yi [and Hou] Ji" ("Gao Yao mo 2") describes his arranging waterways into a two-level system of interconnected waterways for draining the excess waters of the Flood - the higher level of the "nine [main] rivers" jiu chuan 九川, which empty their waters into the seas of the four cardinal directions, and the lower level of "field-drains and [drainage] ducts" quan kuai 畎澮, which drain into the main rivers. ${ }^{50}$ Yet, despite this focus on waterways, arranging space still starts from mountains.

A more elaborate and structurally perfect version of successive drainage system of six levels is featured in the "Shi shui" 釋水 ("Explaining Waterways"), chapter 12 of the Er ya 爾雅 dictionary (ca. $2^{\text {nd }}$ century BC). ${ }^{51}$ The waterways are also listed from large to small, as follows: chuan 川 [main] rivers $\leftarrow x i$ 谿 creeks $\leftarrow g u$ 谷 $g u$ [river] valleys $\leftarrow$ gou 溝 [drainage] ditches $\leftarrow k u a i$ 澮 [drainage] ducts $\leftarrow d u$ 瀆 [drainage] trenches: 52

[Er ya, ch. 12 "Shi shui", §1:]

水注川曰谿, shui zhu chuan yue xi,

注谿曰谷， $\quad z h u g u y u e g u$,

注谷曰溝, zhu gou yue gou,

注溝曰澮, zhu gou yue kuai,

注澮曰瀆. ${ }^{53}$ zhu kuai yue du

Waterways, which pour into the [main] rivers are called creeks; those which pour into creeks are called [river] valleys; those which pour into [river] valleys are called [drainage] ditches;

\footnotetext{
${ }^{50}$ For a recent reassessment of the Flood legend see Allan 2017.

${ }^{51}$ Being drawn from different materials, the Er ya retains some concepts rejected in early imperial historiography, such as the location of the Yellow River source at Kunlun Mountain. In the "Yu gong" the Yellow River begins in Jishi 積石, whereas in late Warring States - Early Han texts such as the Mu Tianzi zhuan 穆天子傳 (“Narrative of the Son of Heaven, Mu”, late 4th-early 3rd cc. BC) and the Shanhai jing 山海經 (“Itineraries of Mountains and SeasW, compiled about the $1^{\text {st }}$ century BC), its begins in Kunlun Mountain. For the ideological importance of determining the 'true' source of the Yellow River in early imperial cartography, see Dorofeeva-Lichtmann 2005-2006.

${ }^{52}$ Precise translation of these waterway terms needs a special study. Here I try to use more or less matching equivalents, different for each different character.

${ }^{53}$ Erya Guozhu 爾雅郭注 (Sibu beiyao ed.), 7.9b. Subsequently, see Erya Guozhu 爾雅郭注 (Sibu beiyao ed.), 7.10a, the drainage trenches $d u$ 瀆 are glossed by the four rivers pouring into the sea: 江河淮 濟為四瀆, 四瀆者, 發源注海者也 Jiang He Huai Ji wei Sidu, Sidu zhe, fa yuan zhu hai zhe ye “The Jiang, He, Huai and Qi rivers constitute the Four [main] drainage trenches; the Four [main] drainage trenches are those who have spouting sources that pour into the sea". However, from the logic of the drainage system described in the "Yi [and Hou] Ji""“Gao Yao mo 2", the four rivers match better as a gloss for the largest waterways in the system - chuan 川.
} 
those which pour into [drainage] ditches are called [drainage] ducts, those which pour into [drainage] ducts are called [drainage] trenches.

While at first sight the richness of the vocabulary for types of waterways in the Er ya is impressive, a closer look reveals that the vocabulary for mountains in this dictionary is even more abundant. Entries about mountains are divided with respect to two categories - "Shi qiu” 釋丘 (“Explaining Peaks", chapter 10) and "Shi shan" 釋山 ("Explaining Mountains", chapter 11). These two chapters precede chapter 12 on waterways, thus again respecting the sequence from mountains to waters. Finally, the sequence from mountains to waters determines the structure of the most comprehensive early Chinese description of the "natural" world in the Shanhai jing 山海經 ("Itineraries of Mountains and Seas", compiled about the $1^{\text {st }}$ century BC), composed of the "Shan jing” 山經 ("Itineraries of Mountains") and the "Hai jing” 海經 ("Itineraries of Seas"). In addition, as in the case of the Erya, it is characterised by the quantitative prevalence of mountains over waters. Firstly, the "mountains" part is about twice as large as the "seas" part. Secondly, the itineraries of the "Shan jing", a detailed version of Yu's land itineraries, are delineated from mountain to mountain. Rivers here are secondary landmarks, subordinated to mountains. They are registered only in cases where they have their source in mountains, and are greatly outnumbered by mountains. ${ }^{54}$

In sum, according to such representative texts as the Shang shu, the Er ya and the Shanhai jing, the conception of terrestrial space builds on the predominance of mountains over rivers. This point is of crucial importance for understanding the message behind the outcome of "performing the gao" in slip 31:

[Rong Cheng shi, slip 31:]

以徫(=越)於溪浴(=谷)，yi wei (yue) yu xi yu， This enabled [him] to traverse brooks and river-valleys, 濟於廣川, ji yu guang chuan, cross broad rivers;

高山侾, gao shan sheng, high mountains became ascendable,

蓁林... zhen lin dense forests...

[end of slip 31]

The wording is very similar to the summaries of space regulation by Shun and Yu in the Shang shu, especially to those by $\mathrm{Yu}$, which are more detailed - they include trees, as attributes of mountains, and supply mountains and rivers with augmenting adjectives, though this is a difference of detail rather than substance. At the same time, in slip 31 the sequence of managing landscape features is inversed - arranging waterways precedes arranging mountains. In addition, moving across terrestrial space is effectuated not with respect to mountains - as a tour of cardinal peaks by Shun or "moving along mountains" (sui shan 隨山) by Yu, but through waterways - "traversing" and "crossing"

\footnotetext{
${ }^{54}$ Dorofeeva-Lichtmann 1995, esp. p. 59, footnote 8, and p. 90, table 1.
} 
them (wei $[=y u e]$ 㦣(=越) and $j i$ 濟, respectively). This is a cardinally different view of terrestrial space, one in which the main structuring elements are waterways. ${ }^{55}$ And, indeed, this characteristic perfectly matches the version of the "Nine Provinces" described in the Rong Cheng shi, which primarily builds on the idea of successive drainage. Its general principle, as mentioned above, is formulated in the "Yi [and Hou] Ji" ("Gao Yao mo 2") and the "Shi shui" through a system of abstract waterways of hierarchically different types. The "Nine Provinces" of the Rong Cheng shi apply this principle to specific waterways and describe the well-known rivers of the Yellow River and the Yangzi River basins as such a system. ${ }^{56}$ The emphasis on waterways in slip 31 correlates with the primary role of waterways in the "Nine Provinces" in this manuscript.

\subsection{Proposed placement of slip 31}

The above comparison of slip 31 with transmitted texts and the correlation of arranging landscape, beginning from waters, with the drainage concept of the "Nine Provinces" allows one to conclude that it most likely refers to the group of slips that describe Shun's and Yu's activities.

In the Shang shu, which became the canonical version of the origins of history in early imperial historiography, one finds an interesting phenomenon - the spatial arrangements of Shun and $\mathrm{Yu}$ are characterised by a certain replication with respect to each other. The similar summaries of Shun's and Yu's management of landscape features progressing from mountains to waters provide a good example. Although Shun's "Twelve Provinces" are only briefly mentioned and Yu's "Nine Provinces" are described in much greater detail, both follow the same principle of managing terrestrial space, where the number of "provinces" is matched by the same number of arranged features of landscape, and is, therefore, also a replication. Shun's and Yu's spatial arrangements are distinguished on a formal level, from the attribution of different numbers to the separation of certain functions. Elsewhere I have discussed that the regulation of space through communicating with spirits shen 神 in the Shang shu is an exclusive prerogative of Shun, but that in transmitted texts not included into the Confucian "canon" this distinction is not respected. ${ }^{57}$ The reason is that, with the exception of the Shang shu and its citations, the division into "provinces" is credited only to $\mathrm{Yu}$, as is the major imput into regulating space in all its aspects. In the Shang shu

\footnotetext{
${ }^{55}$ For the concept of “water" (shui 水) in early Chinese thought and its implications, see Allan 1997.

${ }^{56}$ I have discussed the "Nine Provinces" of the Rong Cheng shi in detail elsewhere, see DorofeevaLichtmann 2010, pp. 37-41. The description of the "Nine Provinces" is reproduced in APPENDIX.

${ }^{57}$ Dorofeeva-Lichtmann 2019 [rev. 2009], pp. 636-644. Thus, in alternative versions of Yu's labours, e.g., in the Shanhai jing, Yu relies heavily on spirits. However, spirits do not play an important role in the Rong Cheng shi. The character shen occurs only once as part of a placename in slip 40, and, through a loan character, in the name of Shen Nong (slip 1), so cannot serve as a criterion by which to distinguish between the functions of Shun and Yu in this manuscript.
} 
the merit is divided between Shun and Yu: as ruler Shun initiated and inspired spatial regulation, while Yu successfully developed on them, having started as Shun's foreman.

The transmitted version of Shun's and Yu's spatial regulations found in the Shang shu, more precisely in the "Shun dian" ("Yao dian 2"), the "Yi [and Hou] Ji" ("Gao Yao mo 2") and the "Yu gong" chapters, underwent considerable editing in becoming the canonical version, which allowed for replication. Replication is also apparent in Yu's regulations - the very similar summaries that precede the draining of excess waters in the "Yi [and Hou] Ji" ("Gao Yao mo 2") chapter and the description of the "Nine Provinces" in the "Yu gong" can be regarded as such. Putting aside the reasons for such replications in the Shang shu, let us strip them down to the basic structural nodes of Shun's and Yu's spatial regulations. These are as follows: Shun performs the ritual regulation of space according to a twelve-fold "cosmograph"-like pattern $\rightarrow$ summary of managed landscape features $\rightarrow$ Yu realises practical regulation of terrestrial space through draining floodwaters and establishing the "Nine Provinces" 58 In the Rong Cheng shi one finds a concise version of these three nodes: a cardinallyoriented scheme of performing twelve gao followed by a summary of managed landscape features in slip 31, and establishing the "Nine Provinces" in the drainage process in slips 24-27. If we take the canonical version of Shun's and Yu's regulations as a basis for comparison, slip 31 most likely refers to Shun's regulations and should precede the description of the "Nine Provinces".

The description of the "Nine Provinces" in the Rong Cheng shi is the core of a definitive group of slips $(23+15+/=24-30)$, nine slips in total, or eight if one considers slips 24 and 15 as pieces of the same slip, the sequence of which is not in doubt. Many scholars now consider slips $16-22$ as belonging to this group, and place them immediately after slip 30 . I suggest that a possible placement of slip 31 could be prior to slip 23. ${ }^{59}$ The beginning of this slip is broken off, but the surviving piece is the second and the final reference to the general state of the landscape in the manuscript, this time in its negative state: after three years of Shun's rulership the landscape features became unmanageable and required Yu's appointment as a foreman:

[Rong Cheng shi, slip 23:]

…舜聽政三年, Shun ting zheng sannian,

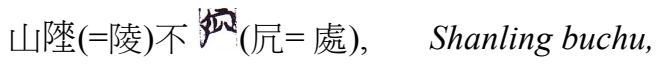

水炎(=潦)不湝(?), Shuilao bujie,

乃立禹以為司工. Nai li Yu yi wei sigong.

Shun administered the government for three years.

${ }^{58}$ A summary of Shun's regulations concludes his "tour of inspection", and in the case of Yu's regulations they precede them, so if one considers them as replications, one can reduce them to one.

${ }^{59}$ The beginning of slip 31 does not fit with the end of slip 12, which since Chen Jian's rearrangement has been accepted as preceeding slip 23 by the majority of scholars. Therefore, such a placing of slip 31 would require further rearrangements. 
[During this time] mountains and hills were uninhabitable, waterways and rainwaters did not flow, [Shun] then established Yu as the Master of Public Works.

This description of terrestrial space as being in disorder follows the common sequence from mountains to waters, because in this way it prioritises the main problem - the "uninhabitability" ( $b u$ chu 不處) of the land. Establishing the "Nine Provinces" in the Rong Cheng shi means solving this problem, as "provinces" are conceived of as pieces of land which have become "suitable for inhabiting, habitable" (ke chu 可處) due to Yu's regulations of waterways. ${ }^{60}$ The description of the disordered landscape in slip 23 alludes to the image of the Flood in the Shang shu - inundated mountains and hills:

[Shang shu, "Yao dian”, Karlgren, § 11, and "Yi [and] Ji”, Karlgren “Gao Yao mo 2", § 9:]

懷山襄陵 huai shan xiang lin

[The waters of the Flood] encircled mountains and rose above the hills.

In addition, the occurrence in the "Yi [and] Ji", Karlgren: "Gao Yao mo 2", is followed by the phrase xia min hun dian 下民昏熱, which can be understood as "people [dwelling] below [live] in semi-darkness and make pillar constructions", implying a difficulty of habitation. ${ }^{61}$ The landscape becoming unmanageable after a certain period of time, as

\footnotetext{
${ }^{60}$ The term 可處 in total is used 6 times (slips 25-27), see Dorofeeva-Lichtmann 2010, pp. 24-27. This character occurs in the manuscript one other time in the meaning "to reside at [place]" (chu yu 處於) in the description of Yao's whereabouts: 昔堯處於丹府與蒦陵之間 Xi Yao chu yu Danfu Dianling zhi jian ("In former times Yao resided between Danfu and Dianling"), slip 6. Altogether this character is found in the Rong Cheng shi 8 times. However, in slip 23 an error in transcription of this character was introduced with the first transcription of the manuscript by Li Ling and has persisted since then in all relevant studies and translations. The graph in slip 23 is drawn in the same way as all its other occurrences in the manuscript, where it is identified with the character $c h u$ 處. Yet, Li Ling identifies it with $x u$ 序 ("to make into a sequence, to order") and Chen Jian with $s h u$ 疏 ("to guide, to direct, to sparse [as a comb sparses hair]"), see Ma Chengyuan (ed.), 2002, p. 267; Chen Jian 2004, p. 329. Yuri Pines and Sarah Allan, following Chen Jian, translate the phrase in question a similar way, as "mountain ranges could not be passed through" or "the mountains and hills did not have passes", respectively, see Pines 2010, pp. 9-10; Allan 2015, pp. 202-203 and 239, see also Allan 2017, p. 27, alluding to Yu's passing through mountains. For comparison, in the Chu Silk Manuscript no.1 the character 處 occurs once, also as a verb and is written in a close, but not completely similar way: 饭, see Li Ling 2013, p. 86, and is transcribed as 层 (inner short text, column 1, character 11), Li Ling 2017, vol. II, p. 229 (here the reference to the occurrence of the character in the text is missing, for the occurrence, see p. 59).

${ }^{61}$ Shangshu zhengyi (Sibu beiyao ed.), 5/1a. This phrase has posed difficulties for commentators and translators, cf. translations of the Flood description by Legge, trans. 1865, pp. 77-78 ( $(1)$; Couvreur, trans. 1897, pp. 49-50 (§ 1); Karlgren, trans. 1950, pp. 9-10 (§ 9). The translation provided here is based on its analysis by my teacher of classical Chinese, Artemy M. Karapetiants, during text-reading seminar of selected chapters of the Shang shu for post-graduate students of the Institute of Asian and African Studies (Moscow State University) in 1990. For the history of dwelling constructions in China, see Liu Dunzhen 刘敦桢 1957.
} 
stated in slip 23, implies that it was manageable before, and from this point of view the proposed sequence of slips 31 and 23 fits. According to the proposed sequence of slips the narrative on the regulation of terrestrial space matches the general logic of its development in the Shang shu: Shun made initial, but insufficient arrangements, and $\mathrm{Yu}$ completed them.

Apart from the summaries on the state of terrestrial space in slips 31 and 23, mountains are mentioned in the Rong Cheng shi only once more, in an enumeration of types of land suitable for habitation - highlands (mountains and hills) and lowlands (ping xi 平隰 plains and marshes):

[Rong Cheng shi, slip 18:]

禹乃因山陵平隰之可邦邑 [end of slip 18; beginning of slip 19: ]者而繁實之.

Yu nai yin shanling pingxi zhi ke bangyi zhe er fan shi zhi

$\mathrm{Yu}$ then, having [established places] suitable for polities and settlements, according to [the configuration of] mountains and hills, plains and marsches, lavishly filled them [with population]. ${ }^{62}$

\subsection{The correlation of mountains and waterways in the Rong Cheng shi and the Chu Silk Manuscript No.1}

References to mountains in this manuscript are not only quite rare - three in total, but in all these cases they refer to generic mountains. ${ }^{63}$ In contrast to mountains, references to waterways in the Rong Cheng shi are not only numerous and diverse, but the majority are specific rivers, lakes and marshes. ${ }^{64}$

Now the question is whether this emphasis on waterways in the Rong Cheng shi is only due to the central role of drainage in the conception of terrestrial space in this manuscript, or whether it may be considered generally characteristic of Chu texts. To this end, let us turn to the Chu Silk Manuscript no.1, which is especially representative for its focus on cosmography. The Chu Silk Manuscript no.1 always respects the sequence from mountains to waters. The traversability both of mountains and rivers, is, however, expressed by a term, the literal meaning of which is to "pass through rivers" (she 涉), similar to the terms for traversability in slip 31 of the Rong Cheng shi. In

\footnotetext{
${ }^{62}$ Pines 2010, p. 12; Allan 2015, pp. 207-208, 245-246.

${ }^{63}$ The names of two specific mountains are found in the Rong Cheng shi, but only as parts of personal or lineage names - 岷山是(=氏) Minshan shi and 鬲山是(=氏) Lishan shi (slips 38 and 40, respectively), and, therefore, not directly related to describing terrestrial space.

${ }^{64}$ In the description of the "provinces" in the Rong Cheng shi (slips 24-27) one finds fourteen specific waterways, see Dorofeeva-Lichtmann 2010, p. 47, table 3.
} 
addition, the Chu Silk Manuscript no.1 is distinguished by a rich diversity of waterways types, the passage below being an example of all three characteristics: ${ }^{65}$

[Chu Silk Manuscript no.1, inner short text, column 3, characters 24-31:]

...以涉山陵瀧泔水澫 yi she shan ling long gan dang wan

...in order to pass through mountains [and] hills, fast waters, dirty waters, reservoirs(?), 10000 rivulets(?)

At the same time, in the Chu Silk Manuscript no.1, mountains are more prevalent than in the Rong Cheng shi. Mountains paired with hills are mentioned in this manuscript three times independently from waterways. ${ }^{66}$ One of these occurrences is of special interest, as it is an attribute of the "Nine Provinces" similar to the pattern found in the "Yu gong":67

[Chu Silk Manuscript no.1, inner short text, column 5, characters 3-10:]

九州不坪 jiuzhou bu ping Nine Provinces were not on the [appropriate] ground-level.

山陵備血矢 shanling bei shi(?) Mountains and hills were about to collapse(?) ${ }^{68}$

Two more references to mountains are found in summaries of the main landscape features, where mountains appear first, but waterways are diverse and in a hierarchy:

[Chu Silk Manuscript no.1, inner short text, column 3, characters 11-14:]

山川四海 shanchuan sihai mountains [and] rivers, the four seas ${ }^{69}$

[Chu Silk Manuscript no.1, inner long text column 11, characters 15-18:]

山川澫浴 shanchuan, wanyu mountains [and] rivers, 10000 rivulets(?) [and] river-valleys. ${ }^{70}$

In sum, both the Chu Silk Manuscript no.1 and the Rong Cheng shi pay considerable attention to waterways. In the former it is manifest through outstandingly diverse terminology for waters. In the Rong Cheng shi there is a quantitative and qualitative predominance of waters over mountains. Though the evidence of these two

\footnotetext{
${ }^{65}$ The Chu Silk Manuscript no. 1 is hereafter referred to according to its transcription by Li Ling following the manuscript's non-linear layout and his sentence-by-sentence comments in his two last books focused on this manuscript, see Li Ling 2013, plate 8 (transcription); 2017, vol. 2, 62 (comments). Translations are by the author of this article.

${ }^{66}$ Inner long text: column 2, characters 19-20; inner short text: column 3, characters 5-6, and column 5, characters 7-8 (Li Ling 2013, plate 8; 2017, vol. 2, p. 48, 61 and 63, respectively). In comparison, "[main] rivers" chuan 川 are mentioned separately once (surrounding text 7, column 1, character 6, see Li Ling 2013, plate 8; 2017, vol. 2, p. 72), “waters" shui 水 twice (inner short text, column 1, character 29; surrounding text 6, column 1, character 7, see Li Ling 2013, plate 8; 2017, vol. 2, p. 60 and 72 , respectively).

${ }^{67} \mathrm{Yu}$ is probably referred to in the manuscript, although the meaning of this occurrence is not clear (inner short text, column 2, character 26).

${ }^{68}$ Li Ling 2013, plate 8; 2017, vol. 2, p. 63.

${ }^{69}$ Li Ling 2013, plate 8; 2017, vol. 2, p. 61.

${ }^{70}$ Li Ling 2013, plate 8, 2017, vol. 2, p. 56.
} 
Chu manuscripts may not be conclusive, they are still representative enough to suggest that the emphasis of waters may be a manifestation of a Chu flavour in conceptualising terrestrial space. Concepts of space are necessarily influenced by the nature of the territory where they are produced. In both manuscripts the travesability of territory is designated by terms for passing through waterways. This can only result from the practice of moving through territories with an abundance of waterways, which is, indeed, the case in the middle and lower parts of the Yangzi River basin. If the hypothesis that a pronounced emphasis on waterways may be characteristic of descriptions of terrestrial space of Chu provenance needs further confirmation, it is undeniable that in the Rong Cheng shi waterways constitute the main structural elements of the conception of space.

\subsection{Drawing a demarcation line along the Han River: cosmographic implication}

This evidence for the predominance of waters in the conception of terrestrial space in the Rong Cheng shi provides the missing context for understanding the conclusion to the description of the "Nine Provinces" in the manuscript, which by definition points to the main outcome of $\mathrm{Yu}$ 's regulations:

[Rong Cheng shi, slips 27-28:]

禹乃

從鷜 $(=$ 灘 $=$ 漢)以南為名浴 $(=$ 谷)五百,

從 [end of slip 27; beginning of slip 28:]

䕿 $(=$ 灘 $=$ 漢 $)$ 以北為名浴 $(=$ 谷 $)$ 五百.

天下之民药(=居) 奠 .

Yu nai cong Han yi nan wei ming yu wubai

Cong Han yi bei wei ming yu wubai

Tianxia zhi min ju dian.

Yu then

to the South from the Han [River] created 500 named river-valleys,

to the North from the Han [River] created 500 named river-valleys.

The dwelling places of people through the Under-Heavens [thus] became settled.

This passage, in effect, concisely formulates the general premises of conceptualising terrestrial space in the Rong Cheng shi. Firstly, waterways are explicitely recognised here as the main structural elements of the mapping of terrestrial space. Secondly, the orderly arrangement of waterways further assures the stability of "dwelling places" ( $j u$ 居) or inhabitable land in the Under-Heavens. As mentioned above, the establishment of the "Nine Provinces" is conceived of as a conversion of "uninhabitable" ( $b u$ chu) landscape into "suitable for inhabiting" (ke chu) pieces of land that emerged when the 
waters were drained. ${ }^{71}$ The stability of "dwelling places" through the entire UnderHeavens is, therefore, the ultimate goal of the "Nine Provinces" in the Rong Cheng shi.

Yet, this does not solve the main puzzle - the unusual division of the mapped terrestrial space into South and North along the Han River. It is even more puzzling that the Han River is not mentioned in the description proper of the "Nine Provinces" or elsewhere in the Rong Cheng shi. This curious reference to the Han River has been noticed only in passing in previous scholarship. The first explorer of the Rong Cheng shi manuscript, Li Ling, simply mentions the noteworthiness of delineating a borderline between the North and the South along the Han River. ${ }^{72}$ Pines is aware that the phrase "hints at the Han River being of central importance for the authors, which would fit nicely with a Chu location", but still believes that "the association with Chu remains very meagre" in the manuscript.

I now argue that the demarcation line along the Han River between the South and the North is the crucial point in the description of the "Nine Provinces" in the Rong Cheng shi, if not the point of it. In order to clarify all the implications of the demarcation line along the Han River, it is necessary to determine how the position of this river was conceived of in early terrestrial descriptions and traditional historical cartography, beginning from the system of the "Nine Provinces".

\section{1. "Provinces" described in the Rong Cheng shi: the method of locating by landmarks}

The new version of the "Nine Provinces" discovered in the Rong Cheng shi attracted much attention from Chinese specialists on manuscripts and concepts of space. ${ }^{73}$ The

\footnotetext{
71 The synonymous characters for inhabitable land in the manuscript $-c h u$ 處 and $j u$ 居 - are distinguished between each other by their shape ( consistently used as a verb "to inhabit, to dwell, to reside" ( 8 occurrences in total, see footnote 60 above). Constance Cook noted a similar distinction between these two characters, which were close in their pronunciation, in the Shifa 筮法 manuscript from the Qinghua University collection of Warring States bamboo slips (Qinghua Daxue cang Zhanguo zhujian 清華大學藏戰國竹簡), see Cook and Zhao Lu 2017.

${ }^{72}$ Ma Chengyuan, ed., 2002, p. 272 (Jianwen yi Hanshui zhide zhuyi 簡文以漢水值得注意).

${ }^{73}$ The peak of scholarly interest are the two first years following the manuscript's publication in 2002, where Li Ling already highlights them in his introduction, see Ma Chengyuan, ed. 2002, p. 249. For the “provinces” proper, see Chen Wei 陳偉 2003, Li Ling 2003, pp. 190-192, Su Jianzhou 蘇建洲 2003, pp. 139-142, §§ 36, 37, 39-41, 45; first published at the Bamboo and Silk forum (Jianbo yanjiu (簡帛研究 www.jianbo.com), 29.03.2003; Yan Changgui 晏昌貴 2004a; 2004): 503-06; first published under a slightly different title at the Bamboo and Silk forum, 6.04.2003; Shen Jianhua 沈建 華 2004; Zhu Yuanqing 朱淵清 2004; first published at the Bamboo and Silk forum, 07.08.2003; Yi Desheng 易德生 2006, 2009; first published at the Bamboo and Silk forum, 5.02.2006 and 27.03.2006, respectively. For related issues, see Chen Jian 2004, first published at the Bamboo and Silk forum, 09.9.2003, Liu Lexian
} 
unusual names of many of the "provinces" in the Rong Cheng shi and the unusual way of describing them in pairs gave an initial impression that a Chu version of the "Nine Provinces" has been discovered. ${ }^{74}$ However, multiple investigations of it showed that, apart from these, the Rong Cheng shi version of the "Nine Provinces" does not contain anything new with respect to transmitted texts. On the contrary, it has multiple parallels with a broad range of transmitted texts, in particular with descriptions of the "Nine Provinces". My own input into these investigations was to evaluate the new version of the "Nine Provinces" with respect to their transmitted accounts and other references to them in terms of conceptualising space. In this respect, this approach reveals the outstandingly eclectic character of the manuscript version of the "Nine Provinces". It combines spatial concepts related to the "Nine Provinces" that became distinct in transmitted texts, and, therefore, throws new light on the group of transmitted sources concerned and their filiation. At the same time, the "Nine Provinces" in the Rong Cheng shi appear to have close affinity with the mainstream representation of the "Nine Provinces", according to the "Yu gong" and its four derivations - the "Youshi lan" 有始 覽 (“Observations on the Beginnings”) chapter of the Lüshi chunqiu 呂始春秋 (compiled by 239 BC), the "Shi di” 釋地 (“Elucidations on the Earth") chapter of the $E r$ $y a$ and the "Zhifang shi” 職方氏 (“Officer in Charge of the Cardinal Directions") chapter of the Zhou li 周禮 ("Zhou Rituals", compiled by the middle of the $2^{\text {nd }}$ century BC). ${ }^{75}$ My method of determining their affinity was to explore the names and types of landmarks that occur in the Rong Cheng shi version of the "Nine Provinces" in comparison to their transmitted descriptions, combining a philological approach with their analysis as markers of "positions" in a conception of space. ${ }^{76}$

Firstly, I compared placenames and the context of their occurrence in the Rong Cheng shi version of the "Nine Provinces" with their transmitted descriptions and other relevant texts. As already mentioned, all landmarks found in the Rong Cheng shi description of the "Nine Provinces" are waterways, and all but one river, Lou 萋, in the most northern "province", overlap with rivers, lakes and marshes found in descriptions

劉樂賢 13.01.2003, Xu Quansheng 許全胜 14.01.2003, Yan Shixuan (Yen Shih-Hsuan) 顏世鉉 20.02.2003, Cheng Yuanmin 程元敏 2004. For a survey of the first series of these studies, see Dorofeeva-Lichtmann 2010, pp. 22-23. For more studies, see Huang Ren'er 黃人二 2005, Fan Guodong 凡國棟 2007, Yin Hongbing 尹宏兵 2007, Du Yong 杜勇 2008 and 2010, Wang Kunpeng 王坤鵬 15.10.2010.

${ }^{74}$ Names of seven "provinces" are not found in other sets of the "Nine Provinces", six "provinces" are described by pairs.

${ }^{75}$ Dorofeeva-Lichtman 2019 [rev. 2009], pp. 595-644; 2010, pp. 13-58.

${ }^{76}$ I discuss the concept of "position" in Chinese cosmography in Dorofeeva-Lichtmann 1996. 
of the "Nine Provinces" of the "Yu gong" group of accounts. ${ }^{77}$ In many cases the context of their occurrence shares the same wording with the transmitted descriptions.

In addition to the usual philological analysis, I explored depictions of waterways found in the Rong Cheng shi description of the "Nine Provinces" in maps showing the "Yu gong" topography. The earliest extant maps of the "Nine Provinces" are known from the Southern Song dynasty. ${ }^{78}$ These maps appeared as a form of commentary on the "Yu gong", and continued to be produced and re-produced from then onwards. Formally referring to the "Yu gong" and mostly based on its topography, these maps sometimes include topographical data from other sources. ${ }^{79} \mathrm{I}$ argue that early Chinese descriptions of terrestrial space cannot be adequately comprehended without taking into consideration traditional Chinese cartography, which continues the same tradition of conceiving of space, and especially not without the historical maps drawn as visual elucidations on early texts. Modern Western maps, often used by default for illustrating early Chinese texts in contemporary studies, are aimed at a topographically accurate and complete representation of the terrestrial surface. Song maps of the "Yu gong" topography are of a radically different - relational, positional or diagrammatic category of maps, typologically similar to relational tree diagrams. ${ }^{80}$ The Song dynasty maps build on a limited selection of landmarks, and aim to show their arrangement with respect to each other, which serves to convey spatial ideas without much concern for topographical accuracy. The majority of landmarks listed in the "Yu gong" and then visualised in maps are inspired by the real topography of the Yellow and the Yangzi river basins, but once selected, these landmarks immediately become markers of relative positions. ${ }^{81}$ Positions in maps can be shifted quite considerably with respect to the real locations of landmarks for the sake of the desired spatial arrangements. In addition, landmarks borrowed from real topography are often transformed and supplemented by landmarks that actually do not exist. ${ }^{82}$

\footnotetext{
${ }^{77}$ For identifications of this river with rivers mentioned in early Chinese terrestrial descriptions, see Dorofeeva-Lichtmann 2010, pp. 32-33; a list of waterways found in the description of the "Nine Provinces" of the Rong Cheng shi is provided in the Annex to the article, see p. 47, table 3.

${ }^{78}$ Two examples of such maps are provided in my survey paper on the transmitted accounts of the "Nine Provinces" and the Rong Cheng shi version in Dorofeeva-Lichtmann 2019 [rev. 2009], Map 1 and 2 on pp. 619-620. For a detailed study of the Song maps related to the "Yu gong", see Hofmann 2007.

${ }^{79}$ For instance, in some maps the Yellow River source is delineated from Kunlun Mountain, as described in the Shanhai jing, and not from Jishi 積石, as according to the "Yu gong", see Dorofeeva-Lichtmann 2005-2006.

${ }^{80}$ These are tentative definitions, a standard term has not yet been worked out. Typology of East Asian maps was recently discussed by Vera Dorofeeva-Lichtmann and Alexei Volkov (2019), their article "Typology of East Asian Maps and Formal Approaches to Their Study" is in preparation for the East Asian Science, Technology and Medicine journal.

${ }^{81}$ In particular, itineraries of the "Yu gong", as well as of the Shanhai jing are chains of relative locations.

${ }^{82}$ One notable non-existent landmark is the "Nine [branches] of the He River" (Jiu He - 九河) located on

"Yu gong" maps in the lower Yellow River valley and apparently inspired by the changing flow of the
} 
While using waterways found in the description of the "Nine Provinces" in the Rong Cheng shi as a means by which to approximate locations of each "province", I combined the application of the Western maps and the "Yu gong" topography maps. ${ }^{83}$ This is not simply circumscribing geographical areas. This method shows the "provinces" of the Rong Cheng shi and their landmarks as elements of relational mapping, and compares them with the relational topography of the "Yu gong". Apart from sharing the same landmarks as markers of the same territorial core with the "Yu gong" group of the "Nine Provinces", the Rong Cheng shi set of "provinces" manifests a typological affinity with them in terms of the relational arrangements of landmarks. ${ }^{84}$

Following the text of the early Chinese written sources and the images of traditional "Yu gong" cartography, I refer to the rivers as they appear in these texts and maps, for instance, He and Jiang not the Yellow River and the Yangzi River. This is because these latter names, especially in the case of the Yangzi, do not always completely correspond to the configuration of landmarks listed in the early sources. In addition, Yangzi is a toponym current in the Western cartography, its Chinese equivalent is a derivate of Jiang - Changjiang 長江 ("Long Jiang”). This approach allows one to understand what precisely is meant in the references to these landmarks in early texts, and is one of the reasons why I provide, in the majority of cases, my own translations of textual passages.

Yellow River. It is usually depicted as a splitting of the Yellow River course into nine separate branches, which unite again before the Yellow river falls into the sea (see Map 4) or less frequently as a widening of its course (see Map 1a). Transformed landmarks are often depicted in a variety of ways. This is the case with the Three Jiang rivers 三江 and the Nine Jiang rivers 九江, although in "Yu gong" topography they are always shown as being around the mouth of the Yangzi (for the Three Jiang) and its middle course for (the Nine Jiang). For a survey of representations of the Nine [branches of the] He River and the Nine Jiang in Song maps of the "Yu gong", see Hofmann 2007, pp. 98-114 and 115-132, respectively. An example of a non-existent landmark difficult to associate with a real river is the Black River (Heishui 黑水), see Hofmann 2007, pp. 133-148. For examples of the Three Jiang, the Nine Jiang and the Black River, see Map 1a and Map 4.

${ }^{83}$ For the approximate regions covered by the "provinces" of the Rong Cheng shi, see DorofeevaLichtmann 2019 [rev. 2009] (Map 4 on page 634, discussed on pp. 630-635) and 2010 (Map 1 on pp. 4648, discussed on pp. 44-45).

${ }^{84}$ It would be interesting to apply this method to one more transmitted set of the "Nine Provinces" found in the "Dixing xun" 墜形訓, chapter 4 of the Huainanzi. Names of "provinces" in this set are radically different from those in the "Yu gong" group. The difference in names is generally explained by the fact that, in contrast to the "Yu gong" group, the Huainanzi extrapolates the $3 \times 3$ grid to mapping the entire inhabited world, see Major 1984, Dorofeeva-Lichtmann 2019 [rev. 2009], table 5 on p. 614 . However, landmarks listed in the Huainanzi to a considerable extent overlap with the landmarks occurring in the "Yu gong" group of descriptions of the "Nine Provinces". In addition, the "Dixing xun" chapter of the Huainanzi has much in common with the "Youshi lan", chapter 13 of the Lüshi chunqiu. It may be interesting to revisit the "Nine Provinces" set of the Huainanzi with the approach I have applied to the Rong Cheng shi description of the "Nine Provinces". 


\subsection{The limits of the "Nine Provinces" : the transgressible and non-transgressible}

The investigation by landmarks of the "Nine Provinces" described in the Rong Cheng shi summarised above was primarily aimed at approximating the areas of single "provinces". Drawing a demarcation line between South and North along the Han River raises the issue of the general area of the territory thus divided and its limits. The limits of the area covered by different sets of the "Nine Provinces" have not yet been systematically discussed in scholarly literature. Under the limits here I mean landmarks, which are conceived of as bordermarkers. I shall investigate them applying the same method, which combines philological analysis with the examination of their positions in maps of the "Yu gong" topography. The limits of the "Nine Provinces" described in the "Yu gong" are defined in the conclusion to their description: ${ }^{85}$

[Shang shu, “Yu gong”, Karlgren, § 38:]
$\begin{array}{lll}\text { 東漸于海, } & \text { Dong jian yu Hai } & \text { In the East washed by the Sea, } \\ \text { 西被于流沙， } & \text { Xi bei yu Liusha } & \text { In the West tucked by the Flowing Sand, } \\ \text { 朔南暨, } & \text { Shuo nan ji } & \text { In the North and the South reach the limits, } \\ \text { 聲教, } & \text { Sheng jiao } & \text { [Yu's] fame and teaching } \\ \text { 訖于四海. } & \text { Qi yu Sihai } & \text { filled up all within the four seas. }\end{array}$

The East and West are delimited by "fluid" boundaries, the Sea and the Flowing Sand, inspired by the East China Sea and the Gobi-Taklamakan desert zone, respectively. ${ }^{86}$ The zone of sand in the Chinese view of space was designated by "watery" characters the character "sand" (sha 沙) has the "water" radical and and its adjective "flowing" (liu 流) is usually applied to rivers. In this way the sand zone in the West made a "fluid" counterpart to the Sea in the East. The indefinite northern and southern limits in the 'Yu gong' are further determined in one of the latest texts related to the "Yu gong" group, the “Wang zhi" 王制 chapter (ca. $2^{\text {nd }}$ century BC) of the Li ji. It does not feature any

\footnotetext{
${ }^{85}$ Difficulties in understanding and alternative interpretations of this passage are discussed by Legge 1865, pp. 150-151 (§ 23); Couvreur 1897, pp. 88-89 (§ 23). See also Karlgren 1950, pages 16 and $18, \S$ 38. The character 聲 sheng ("sound"), here usually translated as "fame", plays an important role in the cardinally-oriented space regulation described in slip 31.

${ }^{86}$ Gobi-Taklamakan is a long desert zone to the North-West of the core Chinese territories. The desert zone includes smaller deserts, the closest of which to the territories covered by the "Nine Provinces", the Tengger and Badain Jaran, are caracterised by sand dunes, which most likely inspired the idea of the Flowing Sand. In traditional Chinese cartography, the Flowing Sand gradually became the name of the Taklamakan Desert, beginning from the Ming dynasty depicted as a cyst-shaped branch of the main part of the desert zone - Shamo 沙漠 (Gobi), literally the Sand Mist, shaped as a thick band, which crosses the north-western periphery of the imperial realm. Although the Gobi is a rocky and pebble-strewn desert, its Chinese name provides clear evidence that in the Chinese tradition of representing space it was conceived of as a sandy desert. For the graphic symbol for a desert zone in Chinese cartography, which appears only in the Ming dynasty, see Kazutaka UNNO, 1981, Papelitzky 2021.
} 
specific set of "provinces", but instead provides a list of measurements, which allow one to assemble an ideal 3x3 square grid framework underlying the "Nine Provinces". The Eastern boundary here appears with the adjective "eastern" - the Eastern Sea, making it a better pair to the Flowing Sand, and the limits in the South and North are marked by mountains, Heng 衡 and Heng1 恆, respectively. Thus, there is the symmetry of the fluid boundaries in the East and West, and the mountains in the South and North:

[ $\mathrm{Li}$ ji, chapter "Wang zhi":]

西不盡流沙，Xi bu jin Liusha In the West does not exceed the Flowing Sand,

南不盡衡山, Nan bu jin Hengshan In the South does not exceed the Heng Mountain,

東不盡東海, Dong bu jin Donghai In the East does not exceed the Eastern Sea,

北不盡恆山. Bei bu jin Henglshan In the North does not exceed the Heng1 Mountain. ${ }^{87}$

Heng and Heng1 mountains are mentioned in the "Yu gong", but not yet as markers of the cardinal points. ${ }^{88}$ It is also noteworthy that in the "Yu gong" the definition of limits is centrifugal - the territories inside extend as far as the defined limits, while in the "Wang zhi" it is centripetal - the territories do not exceed them. The Heng and Heng1 mountains are now identified with real mountains having these names in southern Hunan and northern Shanxi, respectively. One should, however, keep in mind that their actual identifications may have been determined later, and that these mountains may have had alternative identifications, as is the case with many Chinese placenames. For this reason it is especially important to examine depictions of landmarks under these names in traditional Chinese maps, as they show their relative locations. ${ }^{89}$

One of the earliest and the most clearly drawn example of the "Yu gong" maps is the "Map of moving along mountains and deepening rivers, as registered in the $\mathrm{Yu}$ gong” (Yugong suo zai suishan junchuan zhi tu 禹貢所載隨山濬川之圖) from the Collected Commentaries on the Book of Documents (Shu jizhuan 書集傳) completed in 1209 by Cai Shen 蔡沈, also known as Cai Jiufeng 蔡九峰 (1167-1230), see Map 1a. The Eastern Sea and the Flowing Sand, Heng and Heng1 Mountains are prominently

\footnotetext{
${ }^{87}$ Liji Zheng zhu (Sibu beiyao ed.), 4.18a; Legge, 1885, vol. 27, p. 245 (V, § 19); Couvreur 1913, vol. 1, pp. 321-322 (V, § 19).

${ }^{88}$ These mountains belong to the "Five Peaks" (Wuyue 五岳), sets of which can, however, vary in early Chinese sources.

${ }^{89}$ Relative locations can vary between the maps, but only within a limited area. For instance, a landmark associated with the East will never be depicted in the West. Detailed investigation of these variations and their meaning is beyond the scope of this article.
} 
depicted at the corresponding cardinal sides of the map, thus showing how these landmarks demarcate the area, as described in the "Nine Provinces" of the "Yu gong".

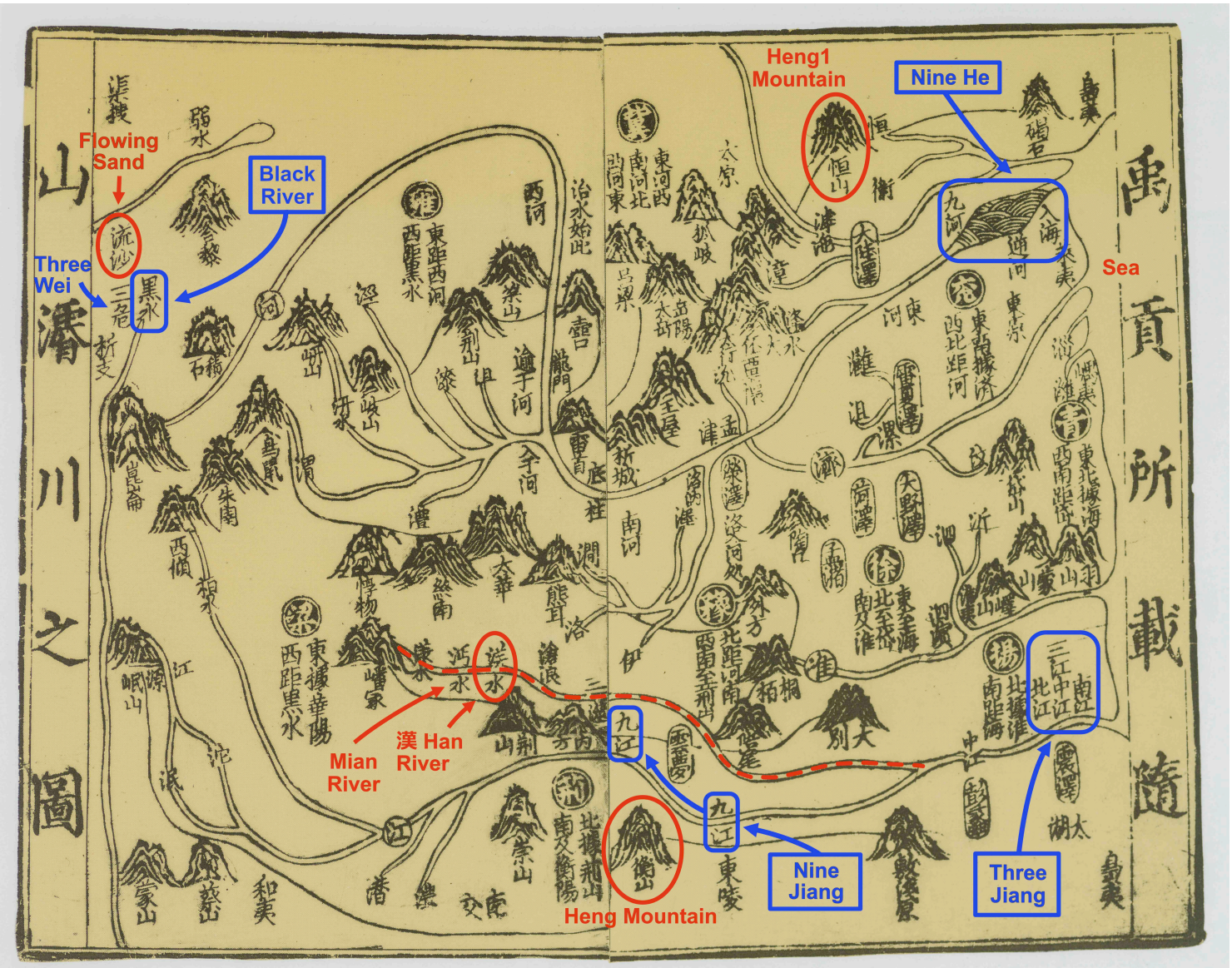

Map 1a. "Map of moving along mountains and deepening rivers, as registered in Yu gong2 (Yugong suo zai suishan junchuan zhi tu 禹貢所載隨山濬川之圖), in: Collected Commentaries on the Book of Documents (Shujizhuan 書集傳) completed in 1209 by Cai Shen 蔡沈/Cai Jiufeng 蔡九峰 (11671230). National Library of China (Beijing) 中國國家圖書館. [Reproduced from Yan Ping 1998, p. 65]. Printed on two pages in a block-printed book, precise dimensions unavailable.

The key difference between the historical "Yu gong"-type maps and maps showing administrative divisions of the Chinese Empire consists in their southern limits. Those of the "Yu gong" topography do not include territories to the South of Heng Mountain, as is the case of the map by Cai Shen. Contemporary maps of the Song Empire, on the other hand, extend to the sea in the South. Especially instructive here are maps that combine both historical and contemporary topography and administrative divisions. One such example was drawn by Cai Shen for the Collected Commentaries on the Book of Documents and, according to its title, aimed at making a comparison between the "Yu gong2 topography and the Song imperial realm - "Map of the Nine Provinces of the $\mathrm{Yu}$ gong of the contemporary provinces and commanderies" (Yugong 
Jiuzhou ji jin zhoujun zhi tu 禹貢九州及今州郡之圖), see Map 1b. Such maps include southern territories between Heng Mountain and the sea in the South, but historical place-names are only given for landmarks to the North of Heng Mountain and are distinguished from contemporary place-names through using different legends.

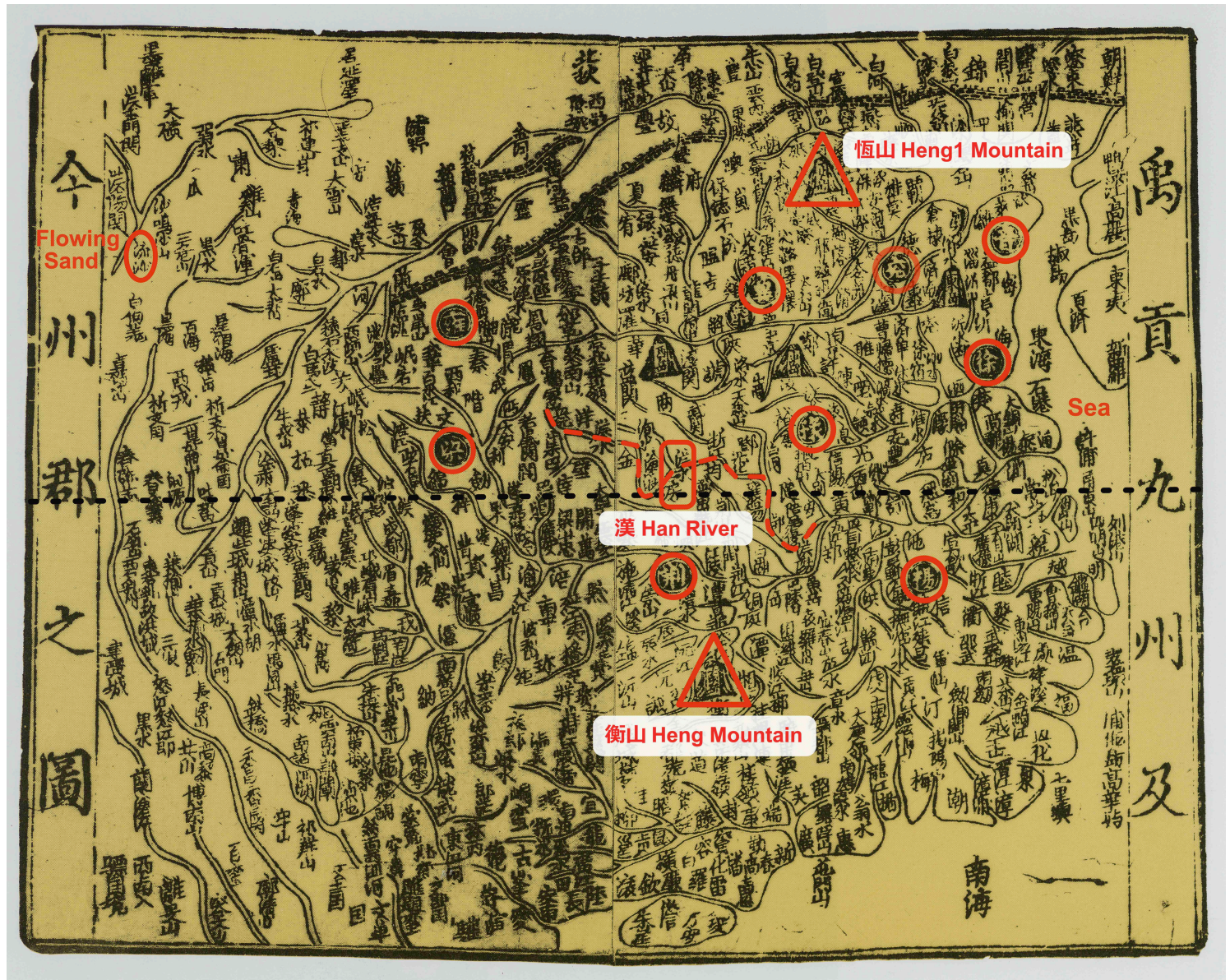

Map 1b. "Map of the Nine Provinces of the Yu gong of the contemporary provinces and commanderies” (Yugong Jiuzhou ji jin zhoujun zhi tu 禹貢九州及今州郡之圖), in: Collected Commentaries on the Book of Documents (Shujizhuan 書集傳) completed in 1209 by Cai Shen 蔡沈 /Cai Jiufeng 蔡九峰 (1167-1230). National Library of China (Beijing) 中國國家圖書館.

Names of the "Nine Provinces" are marked by circles. [Reproduced from Yan Ping 1998, p. 64]. Printed on two pages in a block-printed book, precise dimensions unavailable.

Another example of maps combining "Yu gong" topography with the Song imperial realm is the "Map of Yu's Tracks" (Yuji tu 禹跡圖, ca. 79.0 (80.0) x 77.0 $(79.0) \mathrm{cm}$, engraved in 1136/7), reproduced in all reference studies on the history of Chinese cartogra phy. ${ }^{90}$ This is a rare case of traditional Chinese cartography with a

\footnotetext{
${ }^{90}$ For the pioneering and still most thorough study of the map in the Western languages, see Chavannes 1903. His large-format redrawing of the map with transcription of its characters is reproduced in all the following studies. For a photograph of the stone stele with the map, its rubbing and redrawing with transcription, see the reference atlas of Chinese maps by Cao Wanru 曹婉如 et al. 1999 [repr. 1990],
} 
mathematical background, based on applying a square quantitative grid. The grid scale is $100 \times 100$ li to the division or the grid's check (see Map 1c). ${ }^{91}$

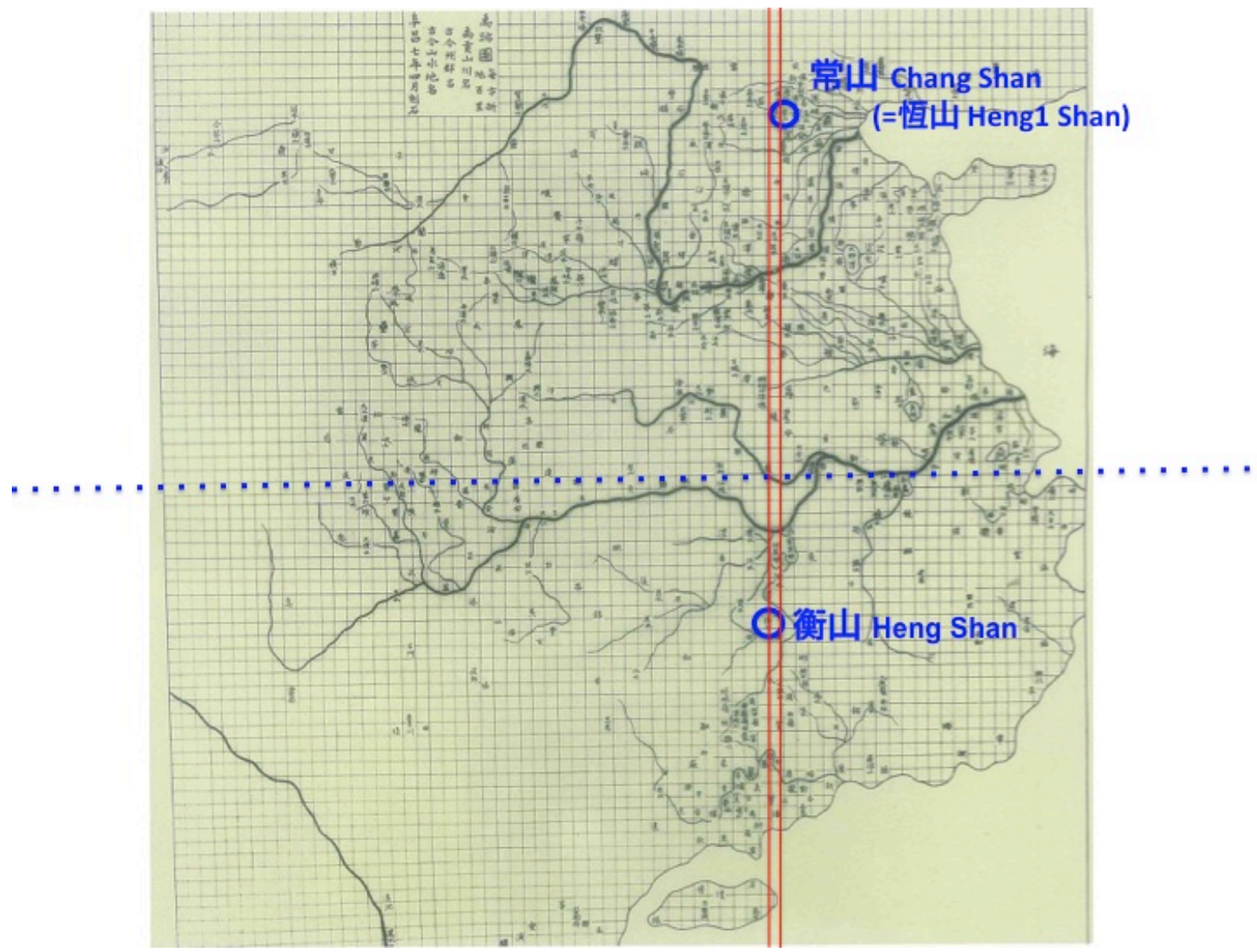

Map 1c. “Map of Yu's Tracks” (Yuji tu 禹跡圖, engraved on a stone stele in 1136/7, ca. 79.0 (80.0) $x 77.0(79.0) \mathrm{cm}$. Redrawing. Square quantitative grid encompassing 72 horisontal and 70 vertical lines of checks; grid scale : 100x100 li to the division; side of a check: ca. 1.1-1.2 cm. [Reproduced from [Cao Wanru 曹婉如 et al. 1999 (repr. 1990), plate 56].

This way of the superimposition of historical cartography on the contemporary imperial realm became especially current in Ming cartography and after, see for instance Map 3 and Map 5.

In terms of modern physical geography, the territory covered by the "Nine Provinces" is delimited in the South by the arc of the Nanling and Wuyi mountain

plates 54, 55 and 56, respectively, for the 1142 AD version of the map, see plates 57-9. For discussions of this map in the two main conceptual histories of the Chinese cartography, see Needham and Wang Ling 1959, pp. 547-549, and Yee 1994, pp. 46-49. See also an interesting revision of this map by Hilde De Weerdt (2009).

91 The definition "square [quantitative] grid" is used in the history of the Chinese geography and cartography by Joseph Needham and Wang Ling 1959. The square quantitative grid is cardinally different from the graticule of latittudes and longitudes - they are based on different principles, but since both have a mathematical background, a grid map can be conformed to the system of latitudes and longitudes, and, therefore, geo-referenced. For an attempt at evaluating the map's topographical precision through its georeferencing, see Akin and Mumford 2012, whose methods were criticised by Volkov 2015 and 2019. 
ranges. These mountains are difficult to cross and thus formed a natural obstacle to going South. ${ }^{92}$ The same applies to depictions of the eastern and the western borders of the "Nine Provinces" in Chinese cartography. These borders are also inspired by serious natural obstacles to territorial extension - the desert region in the North-West and the sea in the East. Maps of the "Nine Provinces" keep strictly to these borders, and in this respect differ from some maps of the contemporary Chinese Empire. Many contemporary maps include the Western Region, and the sea in the East contains the names of insular neighbours. In the "Yu gong" topography maps, the sea is reduced to a thin blank margin, and the Flowing Sand does not have a special cartographic image, being marked only by its name. It is also noteworthy that the Flowing Sand is a natural western limit only of the Yellow River basin, while the Yangzi River basin is delimited by mountaneous areas, though it was the view of the Yellow River Basin that determined the idea of the western boundary of the "Nine Provinces". The "Yu gong" maps adhere to topographical reality and place the Flowing Sand in the North-West.

The situation with the northern boundary is different from all the other cardinal limits of the "Nine Provinces", which are distinguished by the difficult nature of their transgressibility. Some of the "Yu gong" topography maps include landmarks mentioned in the "provinces", which are missing in the initial "Yu gong" set. All these supplementary landmarks are small rivers draining into the Bohai Sea. In the maps in question, this region occupies the north-eastern corner. ${ }^{93}$ One can see from a physical map of China that the Bohai Sea is, indeed, surrounded by lowlands covered by a dense river network, which facilitated territorial expansion, and at the same time is delimited to the West by mountain ranges, thus chanelling expansion in a north-easterly direction, see Map 2a. It is also noteworthy that Heng1 Mountain located almost on the same longitude with Heng Mountain (113 $44^{\prime} 08^{\prime} ' \mathrm{E}$ and $112^{\circ} 41^{\prime} 05^{\prime}$ 'E, respectively) in the "Yu gong" maps, is considerably shifted to the North-East. This shift most likely reflects the impluse towards the North-West. The only exception is the "Map of Yu's Tracks" based on the square quantitative grid. Here the placement of Heng and Heng1 mountains (in this map the latter is given its different name - 常山 Chang Mountain) ${ }^{94}$ is close to their real locations - they are placed along two neighbouring vertical columns of the grid, so that the shift is minimal, see Map 1c. ${ }^{95}$

\footnotetext{
${ }^{92}$ For a long time this natural border protected territories in the South from northern intruders. The southern territories were annexed only with the unification of China into an empire. It is also noteworthy that the southern territories were easier to reach by sailing along the coast.

${ }^{93}$ A highly detailed depiction of these rivers is to be found in the "Map of Yu's Tracks". The data about rivers draining into the Bohai Sea is borrowed mostly from the 'Zhifang shi'.

${ }^{94}$ For the variation in the mountain name, see Nienhauser, ed., 1994, pp. 23-24, footnote 27.

${ }^{95}$ For survey methods that would allow one to locate these two mountains almost along the same lattitude - a large-scale gnomonic survey, see Wu Chia-Yun 2021. She compared some locations in the "Map of Yu's Tracks" with a roughly contemporary map of the imperial realm of the same format, which is not explicitely related to the "Yu gong" and does not contain a square grid - "Map of prefectures and counties of the nine districts” (Jiuyu shouling tu 九域守令圖 engraved on a stone stele in 1121, ca. 130.0 x 100.0
} 


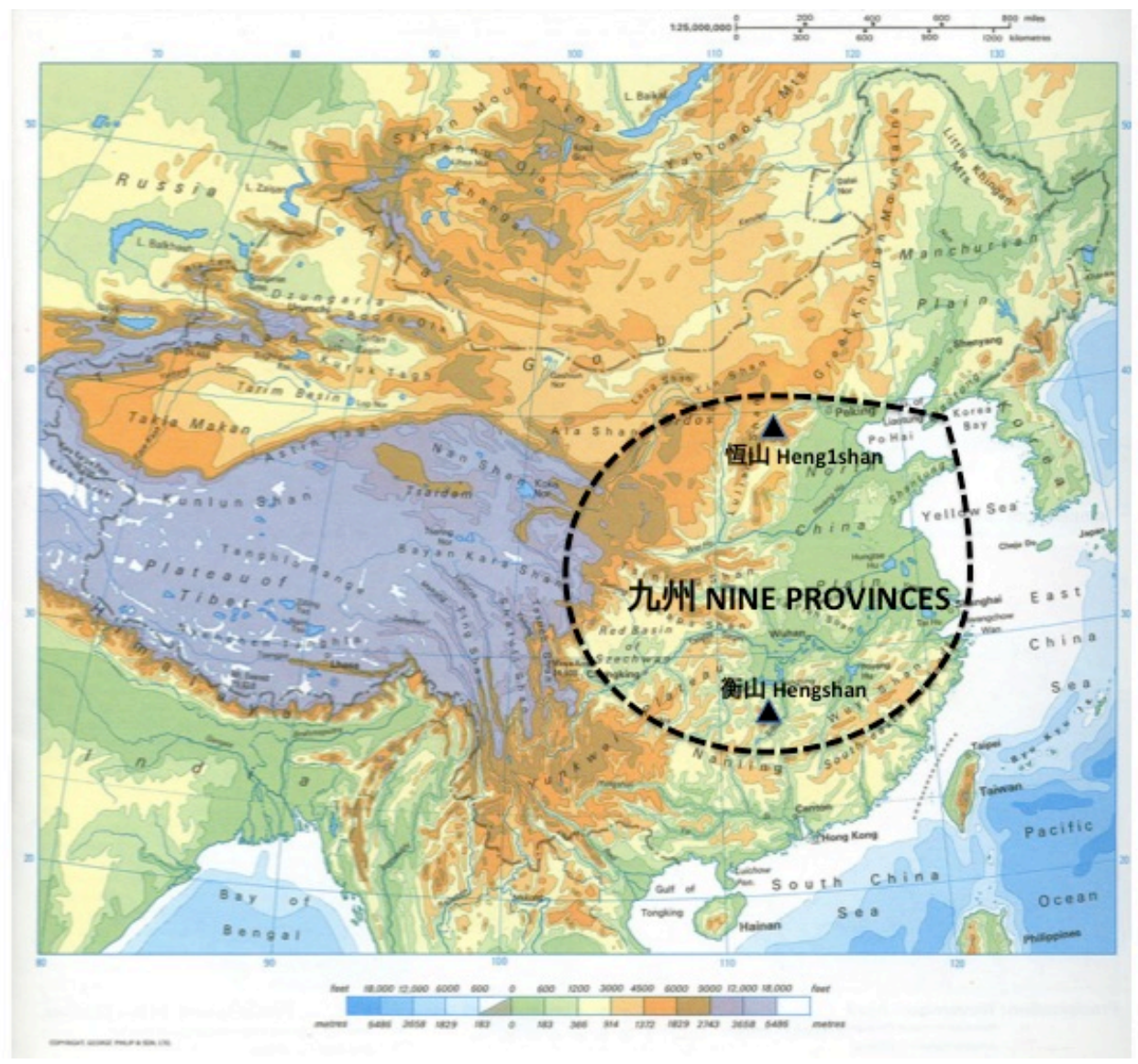

Map 2a. Physical map of China.

In sum, the "Nine Provinces" is a conception of space reflecting the reduced capacity for territorial expansion, with the exception of the north-eastern corridor, as one can grasp from a scheme of the topographical areas of China, see Map 2b, The only flaw of this useful scheme is the lack of a special symbol for the desert area, encompassing the southern part of the Inner Mongolian Plateau and the Tarim basin. This is an interesting echo of the original absence of a special cartographic symbol for desert in Chinese cartography.

cm, see Cao Wanru 1999 [repr. of 1990], plate 65). Some of these locations placed in the "Map of Yu's Tracks" along a vertical line, in the "Map of prefectures and counties of the nine districts" form a line slightly inclined to the north-east. Shifts of locations between the Chinese scaled maps and maps with no explicit scale or diagrammatic maps deserve a more detailed study, which is beyond the scope of this article. 


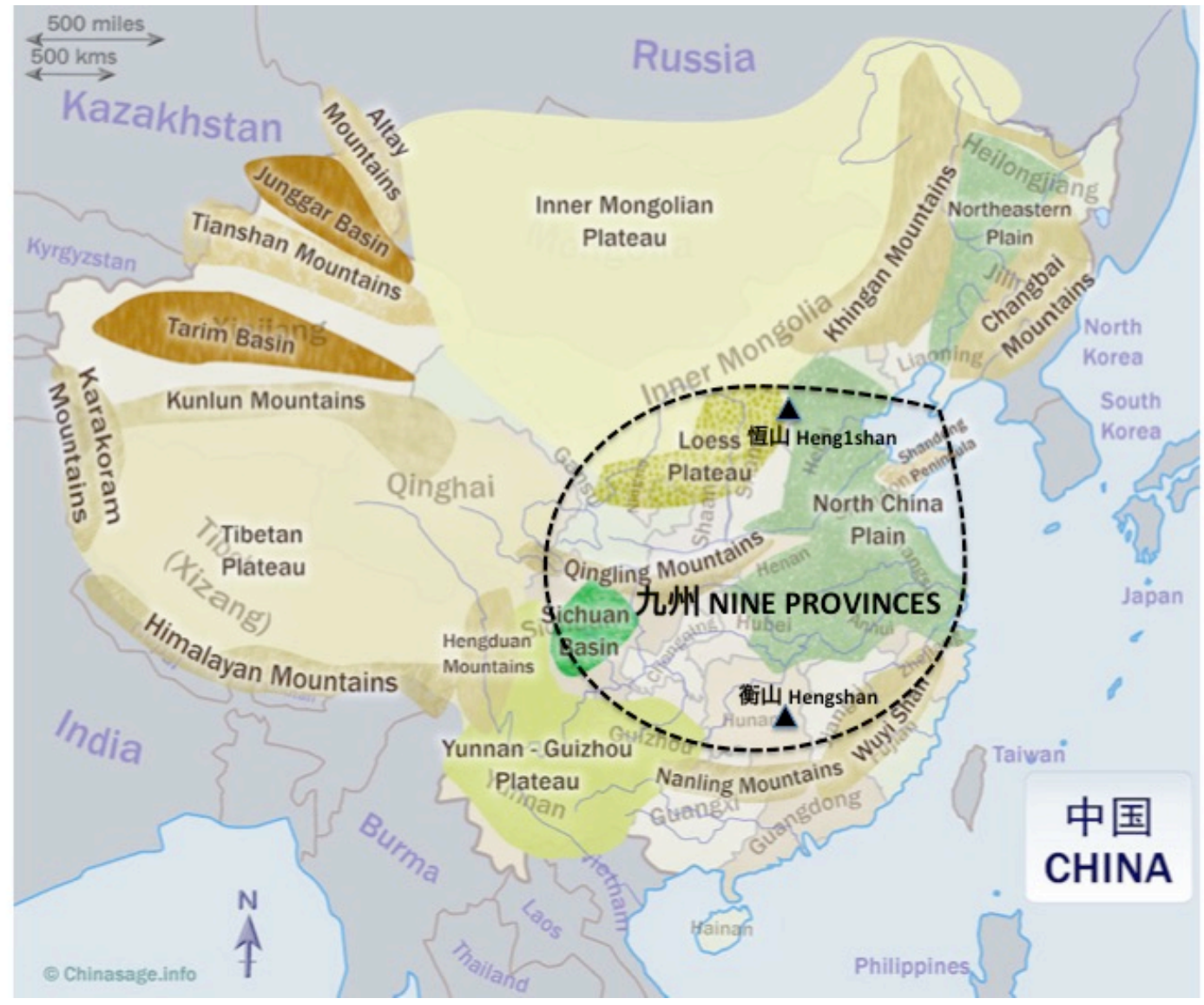

Map 2b. Topographical areas of China.

The "Nine Provinces" sets of the "Yu gong" group differ in one or two positions; altogether they include twelve names of "provinces". 96 This dozen "provinces" is depicted in the "Map of demarcation between the Nine Provinces and the Twelve Provinces of Tang (= Yao 堯) and Yul (=Shun 舜)” (Tang Yu jiuzhou shier zhou fenjie $t u$ 唐虞九州十二州分界圖) from the Yue shi yue1 shu 閱史約書 (“Reviewing History, Weighing Books") by Wang Guanglu 王光魯 (fl. In mid. 17 $7^{\text {th }}$ century) in 5 juan, published in 1643, see Map 3. ${ }^{97}$ In this map, the north-eastern extension is distinguished by means of special cartographic symbols:

- in contrast with all the other sides of the mapped territory, the North-East is not circumscribed by a continuous boundary, thus staying open for further extension;

\footnotetext{
${ }^{96}$ For comparison between the "Nine Provinces" sets of the "Yu gong" group of transmitted texts, see Dorofeeva-Lichtmann 2019 [rev. 2009], pp. 608-611, tables 1-4.

${ }^{97}$ These maps have many topographic characteristics of Ming cartography, e.g., the course of the Yellow River differs from that found on Song maps and the Yellow River source is identified with the Xingxiuhai 星宿海 (Star Lodges Lake), see Dorofeeva-Lichtmann 2012.
} 
- "provinces" missing in the "Yu gong" set are delineated from each other by double borderlines.

From the point of view of its landmarks, the Rong Cheng shi set of the "Nine Provinces" follows the same tendency: it is characterised by a surprisingly large extension to the North-East, and contrary to expectations, does not include any specifically southern landmarks. ${ }^{98}$

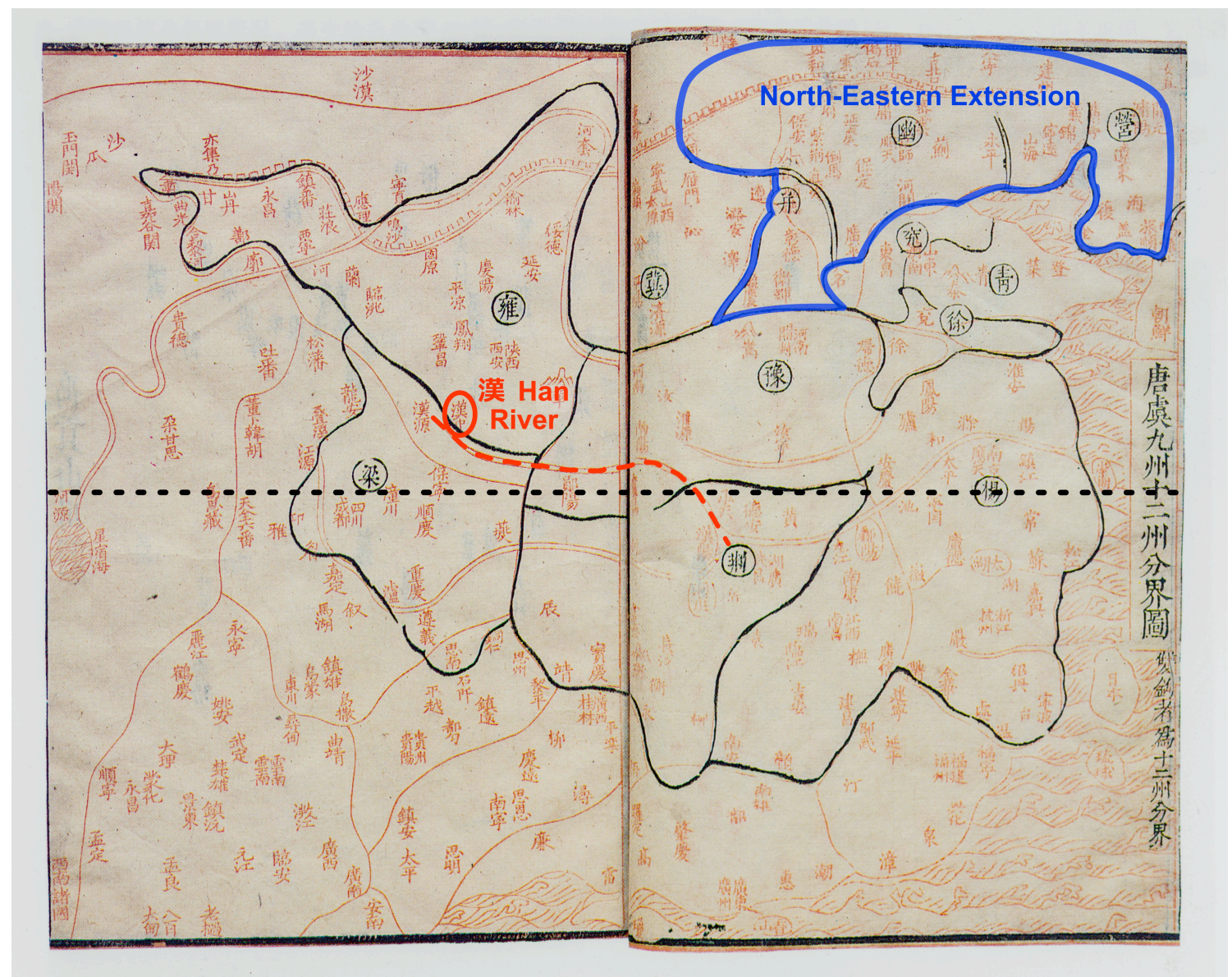

Map 3. "Map of demarcation between the Nine Provinces and the Twelve Provinces of Tang (= Yao 堯) and Yu1 (=Shun 舜)” (Tang Yu jiuzhou shier zhou fenjie tu - 唐虞九州十二州分界圖), in: Yue shi yue1 shu (閱史約書 “"Reviewing History, Weighing Books”) by Wang Guanglu 王光魯 in 5 juan (published in 1643). National Library of China (Beijing) 中國國家圖書館. [Reproduced from Yan Ping 1998, p. 155]. Printed on two pages in a block-printed book, precise dimensions unavailable.

In sum, from the point of view of textual parallels between transmitted descriptions of the "Nine Provinces" and that in the Rong Cheng shi version, and the areas that both the transmitted and the Rong Cheng shi sets of "provinces" fill out by

${ }^{98}$ Dorofeeva-Lichtmann 2010, pp. 31-33. 
landmarks, one can find no specifically Chu spatial concepts in the Rong Cheng shi. This conclusion matches the general impression of the manuscript of Yuri Pines, who notes "a curious lack of any Chu-related trait in the Rong Cheng shi" and its "absence of Chu flavour". "Even if one may question considering the "Nine Provinces" as a "northern" view of the core Chinese territories, ${ }^{100}$ it is still a view that includes a modest share of the southern territories in the Yangzi River basin and an expanding predominance of the "provinces" that belong to the basin of the Yellow River and further North-East.

\subsection{Totals of landscape features as a means of measuring space}

Let us now return to the division of terrestrial space into the southern and the northern clusters of waterways by the Han River, begining with the quantitative implication with respect to the "Nine Provinces". The use of quantitative topographical summaries per se is one of the distinguishing features of early Chinese descriptions of terrestrial space, specifically, the total numbers of waterways found in several Warring States - Former Han texts. Especially interesting is the passage from the "Tianxia" (天下 - "The Under-heavens”) chapter of the Zhuangzi 莊子 citing the philosopher Mozi 墨子 (ca 470 - ca 391 B.C.E.). The passage is not found in the transmitted version of the Mozi treatise, and belongs to the latest layer ("Miscellaneous Chapters" zapian 亲隹篇) of the Zhuangzi, which consists of thirty-three chapters composed from the $4^{\text {th }}$ through the $2^{\text {nd }}$ century BC. "Tianxia" is the last - the thirty-third - in the list of chapters and was apparently composed by Zhuangzi's followers. Yet, the concept referred to in the passage may be dated to the end of Mozi's lifetime that overlaps with the upper chronological limit of the Zhuangzi - the early $4^{\text {th }}$ century BC. Translations of this passage vary considerably in interpretation. ${ }^{101}$ The detailed description in the Rong Cheng shi of how Yu established the "Nine Provinces" through "releasing" jue 決 and “communicating/linking” tong 通 waterways seems to provide the missing details for a better understanding of this passage. ${ }^{102}$ In it the excess waters are drained through a

\footnotetext{
${ }^{99}$ Pines 2010, pp. 25-26.

${ }^{100}$ I regard the "Nine Provinces" as a "northern" view, so does Yuri Pines 2010, pp. 11 and 26. This interpretation is criticised by Allan 2015, pp. 205-206. The Flowing Sand, which works as the western limit only for the Yellow River basin, is, however, a strong argument in favour of the "northern" view.

${ }^{101}$ Zhuangzi jishi 1974, p. 1077; Chen Guying 1983, p. 863; Legge, trans. 1959 [repr. 1885], pp. 659-660; Giles, trans. 1926 [repr. 1889], pp. 441-442; Pozdneeva, trans. 1994 [repr. 1967], p. 357; Watson, trans. 1968, p. 366; Liou, 1969, p. 90; Graham, trans. 1991 [repr. 1981], p. 276; Mair, trans. 1994, p. 337; Malyavin, trans. 2002 [rev. 1995], p. 307.

${ }^{102}$ I discuss the passage from this angle in Dorofeeva-Lichtmann 2010, esp. pp. 40-43 in the context of the concept of "making communicate/linking up" when determining the system of waterways described in the Rong Cheng shi.
} 


\section{hierarchical system of rivers $-\mathbf{3 0 0}$ big rivers, $\mathbf{3 0 0 0}$ of their tributaries and countless small rivers:}

["Tianxia" chapter of the Zhuangzi citing Mozi:]

墨子稱道日:

昔禹之湮洪水,

決江河而通四夷九州也.

名川三百,

支川三千,

小者無數.

禹親自操夢耤而九雜天下之川 ...

Mozi cheng dao yu:

Xi Yu zhi yan Hongshui,

Jue Jiang He er tong Siyi Jiuzhou ye.

Mingchuan sanbai,

Zhichuan sanqian,

Xiaozhe wushu.

Yu qin zi cao tuosi er jiu za Tianxia zhi chuan...

Mozi, praising [his] teaching, said:

In former times when $\mathrm{Yu}$ was draining off the floodwaters, ${ }^{103}$

[he] released the Jiang and He [rivers]

and made communicate [via waterways the territories of]

the barbarians of the four [cardinal directions] and the Nine Provinces.

The [number of resulted] named rivers is 300 ;

The [number of their] tributary rivers is 3000 ;

Small [rivers] are countless.

$\mathrm{Yu}$ personally himself operated the sack/basket [for collecting soil] and ploughshare and [thus within] the Nine [Provinces] interlaced the rivers of the Under-heaven...

A more complete hierarchy of waterways is provided in the "Youshi lan" 有始覽 chapter of the Lüshi chunqiu 呂始春秋 (compiled by 239 BC). ${ }^{104}$ Here there are 6 magistral [river] valleys, 600 main rivers, 3000 tributaries and more than 10000

\footnotetext{
${ }^{103}$ A similar phrase is found in the Hong fan 洪範 (“The Great Model”) chapter of the Shang shu, but it refers to Yu’s father, Gun 鯀, who was appointed first by Yao to fight the Flood : ...昔鯀堙洪水 “....in former times Gun dammed up Floodwaters", see Shangshu zhengyi, Sibu beiyao ed., 12/2a; Legge, trans. 1865, p. 323 (§3); Couvreur, trans. 1897, p. 195 (§ 3); Karlgren, trans. 1950, pp. 28-29 (§ 3); see also a study focused on Hong fan by Nylan 1992, p. 112. The same idea is developed in the concluding paragraph of the Shanhai jing: 鯀䩹帝之息壤以堙洪水 “Gun has stolen alluvial(?) soil belonging to the Emperor in order to dam up the Flood", see Shanhai jing jianshu, Sibu beiyao ed. 18/8b; Yanshina, trans. 1977, p. 129; an annotated translation is by Mathieu, trans. 1983, vol.1, pp. 651-652. Gun's method failed and he was executed. Yu did the opposite and succeeded - he released excess waters. In the citation from Mozi, instead of 堙 yin (to dike, to block up; mound, blockage) appears yin 酒 with the "water" radical, which means "to spread, to blot [as ink]". However, taking into consideration the irregular use of radicals in early China, the phrase attributed to Mozi is not very clear.

${ }^{104}$ Lüshi chunqiu, Sibu beiyao ed., 13/3a; Wilhelm, trans. 1928, p. 159; Kamenarovic, trans. 1998, p. 195; Knoblock and Riegel, trans. 2000, p. 281 ( $\S 13 / 1.9-10)$; Tkachenko, trans. 2001, p. 182.
} 
small rivers. ${ }^{105}$ These totals are not strictly related to Yu's ordering of terrestrial space, but are part of the "fundamental structural principles (literally: "beginnings" shi 始)" of the Universe (Heavens and Earth) listed at the beginning of this chapter. Except for the mention of the Heavens at the head of the list, all other attributes are of ordered terrestrial space:

[Lüshi chunqiu, ch. 13 "Youshi lan”, § 1 "You shi” 有始:]

天有九野, Tian you Jiuye Heavens have Nine Fields,

地有九州, di you Jiuzhou, Earth has Nine Provinces,

土有九山, tu you Jiushan, Soil has Nine Mountains,

山有九塞, shan you Jiusai, Mountains have Nine Block-stations,

澤有九數, ze you Jiusou, Marshes have Nine Swamps,

風有八等, feng you Badeng, Winds have Eight Degrees (Directions),

水有六川. shui you Liuchuan Water(way)s have Six [Main] Rivers.

Each of these total numbers of attributes is further elucidated by names of their constituent elements, e.g. names of each "province", mountain etc. The "Six [Main] Rivers" include the He 河, the Chi (=Red) 赤, the Liao 遼, the Hei (=Black) 黑, the Jiang 江 and the Huai 淮 rivers, but not the Han River, which is featured so prominently in the Rong Cheng shi. The list of rivers is followed by dimensions of the earth surface "Inside the Seas" (Hainei 海內) and the totals of its waterways:

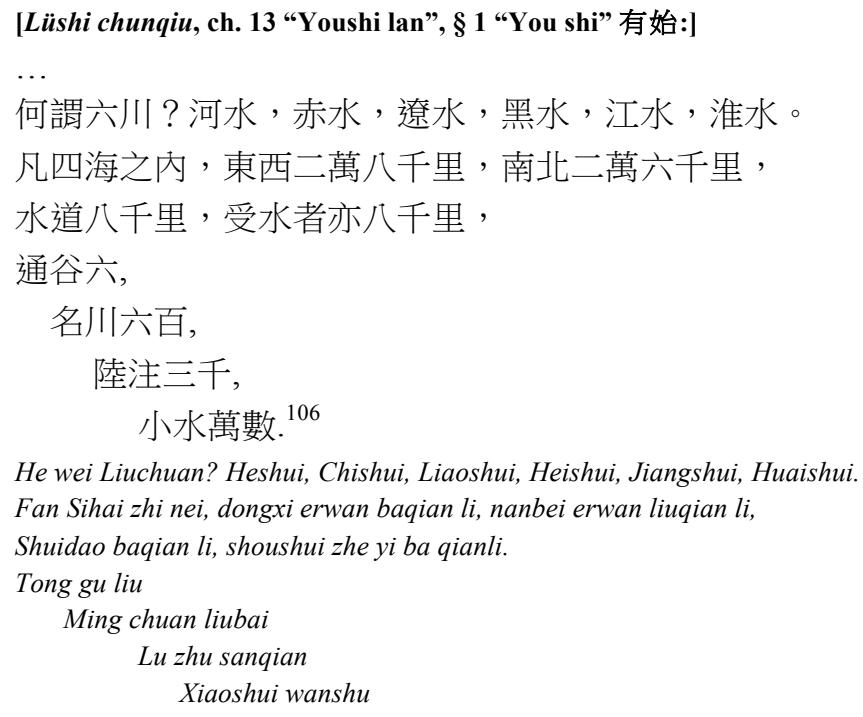

${ }^{105}$ The term tong $g u$ 通谷 is translated hereafter as “magistral [river] valley”, in the sense of a water artery that accumulates the flows of medium and small water courses with their tributaries and channels them further, in this case into the sea.

${ }^{106}$ Here wanshu 萬數 paraphrases wushu 無數 “countless" in the counterpart passage in the Zhuangzi and should be therefore be translated as "counted in their 10000's". The totals of waterways are followed by huge dimensions of the universe between its four ultimate cardinally-oriented points 極 $j i$. 
What is meant by the "Six [Main] Rivers"? The He River, the Red River, the Liao River, the Black River, the Huai River.

In sum, the inside the four [cardinally-oriented] seas is

28000 li long from the East to the West,

26000 li long from the South to the North.

River itineraries are 800 li long; rivers receiving confluents [= big rivers] are also 800 li long.

There are 6 magistral [river] valleys,

600 named rivers,

3000 pouring from the [high]lands,

small waterways are counted in their 10000's.

The 6 magistral [river] valleys apparently correspond to the six main rivers, as specified above, which gives a clear "point of entrance" into the waterway system. The "Youshi lan" totals are reproduced in a simplified way in the "Dixing xun" 墬形訓 chapter of the Huainanzi 淮南子 (complied by $139 \mathrm{BC}$ ), and explicitly in the context of Yu's ordering of terrestrial space. The "Dixing xun" copies much of the "Youshi lan" passage, except for the names of the "Nine Provinces" and the detailed hierarchy of waterways. It only refers to unnumbered "magistral [river] valleys" tong $g u$ 通谷 and 600 big rivers. However, the total length of "land itineraries" lu jing 陸徑 of $3000 l i$ is an interpretation of the ambiguous "land(?) confluents" lu zhu 陸注 listed in the "Youshi lan" and indirectly continues the decimal sequence of totals of waterways: ${ }^{107}$

[Huainanzi, ch. 4 "Dixing xun"]

闔四海之內, 東西二萬八千里, 南北二萬六千里,

水道八千里,

通谷其名川六百,

陸徑三千里.

Gai Sihai zhi nei, dongxi erwan baqian li, nanbei erwan liuqian li,

Shuidao baqian li,

Tonggu qi mingchuan liubai,

Lujing sanqian li.

To sum up, the inside the four [cardinally-oriented] seas is 28000 li long from the East to the West, $26000 l i$ long from the South to the North.

River itineraries are 800 li long,

As far as the magistral [river] valleys [are concerned], its named river flows are 600 ,

The land itineraries are 3000 li long.

A list of distances totals, in its turn, derived from the "Dixing xun" is found in the conclusion to the first part of the Shanhai jing, the "Shan jing" or the "Wuzang

${ }^{107}$ Huainan honglie jijie 1989, p. 132; Major 1993, pp. 147-150 (Section II); Le Blanc and Mathieu, trans. 2003), pp. 163-164; Major et al. 2010, p. 155 (\$4.2). As in the "Youshi lan", the total numbers also conclude with huge dimensions of the universe between its four ultimate points. 
Shanjing”五藏山經 (“Five Treasuries: the Itineraries of Mountains”). ${ }^{108}$ By definition, the "Shan jing" privileges total numbers related to mountains, and develops on the lengths of itineraries by land and by rivers, but total numbers of waterways are not included:

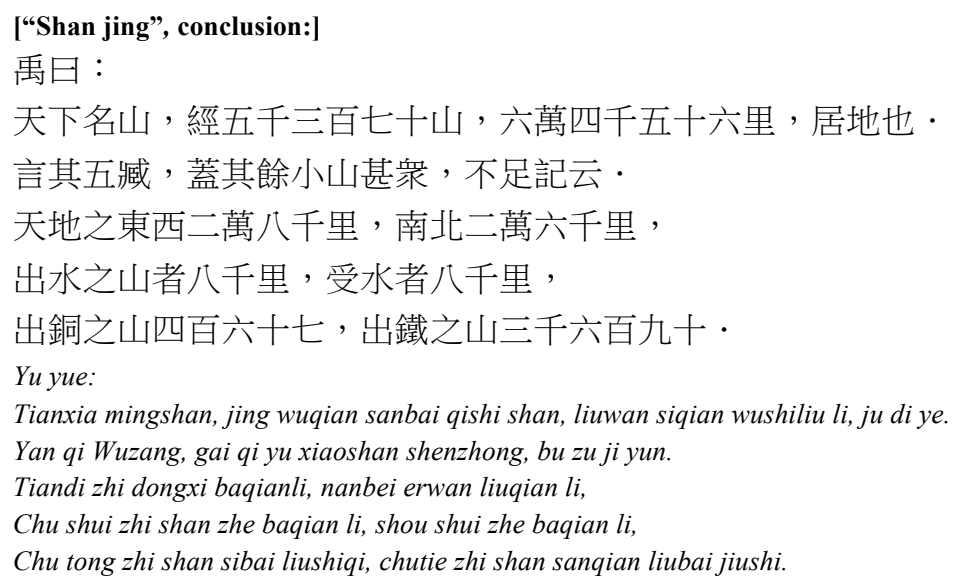

Yu said: [as far as] the named mountains of the Under-heavens [are concerned], [I] passed through and thus linked by itineraries ${ }^{109} 5370$ mountains, [the established itineraries are] $64056 \mathrm{li}$ [long], [these are the dimensions of] dwelling/inhabitable land.

They are called the "Five Treasuries",

In sum, the other smaller mountains are extremely numerous, cannot even be recorded.

Heavens and Earth are $28000 \mathrm{li}$ [long] from the East to the West,

$26000 l i$ [long] from the South to the North.

Mountains being sources of rivers, [these rivers are] $800 \mathrm{li}$ long,

Rivers receiving confluents ( $=$ big rivers) are 800 li long,

There are 467 mountains producing copper, 3690 mountains producing iron.

The series of passages discussed above manifest a chain of filiations from the Mozi citation in the Zhuangzi to the "Youshi lan", then the "Dixing xun" and, finally, the conclusion to the "Shan jing", as summarised in Table 1. ${ }^{110}$ The most structurally complete four-level system of waterways appears in the "Youshi lan". It is typologically similar to the drainage systems described in the "Yi [and Hou] Ji" (Karlgren: "Gao Yao mo 2", § 9) and the "Shi shui" chapter of the Er ya discussed in Part 1.3 above, with the difference that the focus is not on the drainage aspect, but on the number of different

\footnotetext{
${ }^{108}$ See Shanhai jing jianshu 5/44b-45b; Yanshina, trans. 1977, pp. 93-94; Mathieu, trans. 1983, pp. 371372. For some of these totals, see Dorofeeva-Lichtmann 2007, pp. 254-255.

${ }^{109}$ For the meaning of the character jing 經 in this passage, see Dorofeeva-Lichtmann 2007, pp. 253-259.

${ }^{110}$ The filiation line "Youshi lan" $\rightarrow$ "Dixing xun" $\rightarrow$ "Shan jing" does not raise any doubts. One could argue that the Mozi in the Zhuangzi was rather inspired by the "Youshi lan", but according to the juxtaposition of classifications of waterways in Table 1 it seems more likely that the idea advanced by Mozi was developed in the Lüshi chunqiu and then concisely cited in the Huainanzi.
} 
types of waterways. In the "Youshi lan" the system of waterways also becomes supplemented by dimensions of inhabitable space and total lengths of river itineraries. The "Shan jing" develops the same template, having replaced rivers by mountains. The reference to the arrangement of waterways with respect to the Han River in Rong Cheng $s h i$ is a congener, but from an apparently different branch.

Table 1. Text filiations

\begin{tabular}{|c|c|c|c|c|c|}
\hline & $\begin{array}{l}\text { "Tianxia," } \\
Z \text { Zhuangzi } \\
4^{\text {th }}-2^{\text {nd }} \text { cc. } \\
\text { B.C.E. } \\
\text { (citation of } \\
\text { Mozi, ca } 470 \text { - } \\
\text { ca 391 B.C.E.) }\end{array}$ & $\begin{array}{l}\text { "Youshi lan," } \\
\text { Lushi chunqiu } \\
\text { shortly before } 239 \\
\text { B.C.E. }\end{array}$ & $\begin{array}{l}\text { "Dixing } \\
\text { xun," } \\
\text { Huainanzi } \\
\text { shortly before } \\
\text { 139 B.C.E. }\end{array}$ & $\begin{array}{l}\text { "Shan jing" } \\
\text { (conclusion) } \\
\text { compliled about the } 1^{\text {st }} \\
\text { c. B.C.E. }\end{array}$ & $\begin{array}{l}\text { Rong Cheng shi } \\
\text { late } 4^{\text {th }} \text { c. B.C.E. }\end{array}$ \\
\hline \multicolumn{6}{|l|}{$\begin{array}{l}\text { Text filiation } \\
\text { with respect to } \\
\text { totals of } \\
\text { distances }\end{array}$} \\
\hline $\begin{array}{l}\text { Text filiation } \\
\text { with respect to } \\
\text { totals of } \\
\text { landmarks }\end{array}$ & \multicolumn{3}{|c|}{ totals of waterways } & totals of mountains & \\
\hline $\begin{array}{l}\text { Totals of } \\
\text { mountains } \\
\text { and total } \\
\text { length of land } \\
\text { itineraries }\end{array}$ & & & & $\begin{array}{l}\text { 天下名山, 經五千三 } \\
\text { 百七十山, } \\
\text { 六萬四千五十六里, } \\
\text { 居地也·言其臓· } \\
\text { 蓋其餘小山甚衆, } \\
\text { 不足記云 · } \\
\text { [As far as] the named } \\
\text { mountains of the Under- } \\
\text { heavens [are } \\
\text { concerned], } \\
\text { [Yu] passed through and } \\
\text { thus linked by itineraries } \\
\text { 5370 mountains, } \\
\text { [the established } \\
\text { itineraries are] 64056 li } \\
\text { [long], } \\
\text { [these are the } \\
\text { dimensions of] } \\
\text { dwelling/inhabitable } \\
\text { land. } \\
\text { They are called the } \\
\text { "Five Treasuries.” In } \\
\text { sum, the other smaller } \\
\text { mountains are extremely } \\
\text { numerous, cannot even } \\
\text { be recorded. }\end{array}$ & \\
\hline $\begin{array}{l}\text { Length\&width } \\
\text { of inhabitable } \\
\text { space }\end{array}$ & & $\begin{array}{l}\text { 凡四海之內, } \\
\text { 東西二萬八千里, } \\
\text { 南北二萬六千里, } \\
\text { In sum, the inside } \\
\text { the four } \\
\text { [cardinally- } \\
\text { oriented] seas is } \\
28000 \text { li long from } \\
\text { the East to the } \\
\text { West, } \\
26000 \text { li long from } \\
\text { the South to the } \\
\text { North. }\end{array}$ & $\begin{array}{l}\text { 闔四海之內, } \\
\text { 東西二萬八千 } \\
\text { 里, } \\
\text { 南北二萬六千 } \\
\text { 里, } \\
\text { To sum up, the } \\
\text { inside the four } \\
\text { [cardinally- } \\
\text { oriented] seas is } \\
28000 \text { li long } \\
\text { from the East to } \\
\text { the West, } \\
26000 \text { li long } \\
\text { from the South to } \\
\text { the North. }\end{array}$ & $\begin{array}{l}\text { Heavens and Earth are } \\
28000 l i[\text { long] from the } \\
\text { East to the West, } \\
26000 l i \text { long] from the } \\
\text { South to the North. }\end{array}$ & \\
\hline
\end{tabular}




\begin{tabular}{|c|c|c|c|c|c|}
\hline $\begin{array}{l}\text { Length of } \\
\text { river } \\
\text { itineraries }\end{array}$ & & $\begin{array}{l}\text { 水道八千里, } \\
\text { 受水者亦八千里, } \\
\text { River itineraries are } \\
800 \text { li long; rivers } \\
\text { receiving } \\
\text { confluents [= big } \\
\text { rivers] are also } 800 \\
\text { li long. }\end{array}$ & $\begin{array}{l}\text { 水道八千里. } \\
\text { River itineraries } \\
\text { are } 800 \text { li long, }\end{array}$ & $\begin{array}{l}\text { 出水之山者八千里, } \\
\text { 受水者八千里, } \\
\text { Mountains being } \\
\text { sources of rivers, [these } \\
\text { rivers are] } 800 l i \text { long, } \\
\text { Rivers receiving } \\
\text { confluents (= big rivers) } \\
\text { are } 800 l i \text { long, }\end{array}$ & \\
\hline \multirow[t]{2}{*}{$\begin{array}{l}\text { Totals of } \\
\text { waterways } \\
\\
\text { max. } \\
4 \text { levels of } \\
\text { waterways: } \\
\text { I. 通谷 } \\
\text { magistral [river] } \\
\text { valleys } \\
\text { II. 名川 } \\
\text { named rivers } \\
\text { III. secondary } \\
\text { rivers } \\
\text { IV. small } \\
\text { rivers }\end{array}$} & $\begin{array}{l}\text { The [number of } \\
\text { resulted] named } \\
\text { rivers is 300; } \\
\text { the [number of } \\
\text { their] tributary } \\
\text { rivers is 3000; } \\
\text { small [rivers] } \\
\text { are countless. }\end{array}$ & $\begin{array}{l}\text { 通谷六, } \\
\text { 名川六百, } \\
\text { 陸注三千, } \\
\text { 小水萬數 } \\
\text { There are } \\
\mathbf{6} \text { magistral [river] } \\
\text { valleys, } \\
\mathbf{6 0 0 ~ n a m e d ~ r i v e r s , ~} \\
\mathbf{3 0 0 0} \text { pouring from } \\
\text { the [high]lands, } \\
\quad \text { waterways } \\
\text { small } \\
\text { are counted in their } \\
\mathbf{1 0 0 0 0 ' s .}\end{array}$ & 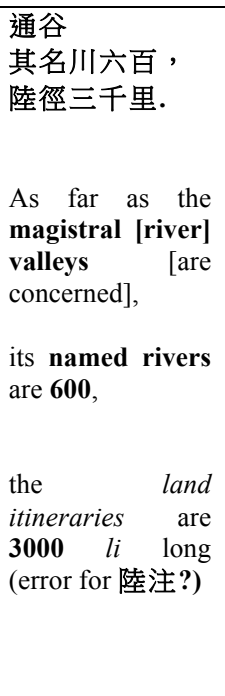 & & \\
\hline & & & & & $\begin{array}{l}\text { 禹乃 } \\
\text { 從漢以南 } \\
\text { 為名浴(=谷)五百, } \\
\text { 從漢以北 } \\
\text { 為名浴(=谷)五百. } \\
\text { Yu then } \\
\text { to the South from the } \\
\text { Han [River] created } \\
500 \text { named river- } \\
\text { valleys, } \\
\text { to the North from the } \\
\text { Han [River] created } \\
500 \text { named river- } \\
\text { valleys. } \\
\text { The dwelling places } \\
\text { of people through } \\
\text { the Under-Heavens } \\
\text { [thus] became } \\
\text { settled. }\end{array}$ \\
\hline $\begin{array}{l}\text { Totals of } \\
\text { mountains }\end{array}$ & & & & $\begin{array}{l}\text { 出銅之山四百六十 } \\
七, \\
\text { 出鐵之山三千六百九 } \\
\text { 十. } \\
\text { There are } 467 \\
\text { mountains producing } \\
\text { copper, } 3690 \text { mountains } \\
\text { producing iron. }\end{array}$ & \\
\hline
\end{tabular}

The common feature of all these totals is the adjective ming 名 to the higher types of landmarks. It is usually translated as "famous", but I suggest that they may rather mean "important landmarks with fixed names" versus smaller landmarks of no importance. Some evidence for this suggestion is found in the Chu Silk Manuscript no.1, where the 
naming of landscape features is a means for putting them in order, possibly by the Emperor Yu, who may be mentioned just before (Chu Silk Manuscript, inner short text, column 2, character 26). The character ming 名 is replaced here by its homophone ming1 命:

[Chu Silk Manuscript, inner short text, column 3, characters 5-14:]

山陵不斌, 乃命山川四海 shanling bu bin, nai ming1 shanchuan sihai

Mountains and hills were not refined, then named mountains and rivers, the four seas. ${ }^{11}$

At the same time, the total numbers of waterways in the Rong Cheng shi differ in several interesting respects from those found in the Zhuangzi, Lüshi chunqiu and Huainanzi:

1) The Rong Cheng shi provides the total of "named" (ming 名) river-valleys designated by the character $y u$ 浴, which consists of the radical “water” 水 shui and the semantic element “valley" $g u$ 谷, the radical accentuating its relation to waterways. The same vocabulary is found in the Chu Silk Manuscript no.1 (shanchuan, wanyu 山川澫浴 “mountains [and] rivers, 10000 rivulets(?) [and] river-valleys"). ${ }^{112}$

2) The "named river-valleys" ming $y u$ 名浴 is a fusion of the "magistral [river] valleys" tong $g u$ 通谷 and the “named rivers" ming chuan 名川, distinguished in the Lüshi chunqiu and the Huainanzi, as the two higher levels of waterways.

3) In contrast to the transmitted texts, in the Rong Cheng shi there is no hierarchy of waterways. Instead they are arranged into two quantitatively equal cardinally-oriented parts: 500 "named river-valleys" in the South and 500 "named river-valleys" in the North. This spatial arrangement of the total numbers of waterways is nowhere in evidence in transmitted texts. The equality of the southern and northern parts is accentuated by the term, which appears in the phrase, which immediately follows: 天下民居奠 Tianxia min $j u$ dian "The dwelling places of people through the Under-Heavens [thus] became settled". 奠 depicts a ritual vessel on an altar and implies something being perfectly balanced.

4) The total number of 300 "named rivers" in the Zhuangzi is doubled to 600 in the "Youshi lan", which also adds a matching upper hierarchical level of 6

\footnotetext{
${ }^{111}$ Li Ling 2013, plate 8; 2017, vol. II, p. 61.

${ }^{112}$ See footnote 70 above.
} 
"magistral [river] valleys". 113 The southern and northern "river-valleys" in the Rong Cheng shi altogether make up a considerably larger total number of 1000 .

I believe that the numerical rise in the total numbers of landscape features conveys an idea of territorial expansion. In the case of the "Youshi lan" it may correspond to the extension of this set of the "Nine Provinces" to the North-East. The 1000 "named river-valleys" have to be seen in the context of the spatial implication of the South-North division along the Han River.

\subsection{The Han River in Chinese cosmography and cartography}

To begin with, a territorial division into two equal halves along the Han River does not match the area encompassed by the transmitted and the Rong Cheng shi sets of the "Nine Provinces".

In transmitted descriptions of the "Nine Provinces", the Han River is used as a boundary marker between "provinces" twice - in the "Youshi lan" and the "Shi di". According the "Youshi lan", the Han River together with $\mathrm{He}$ delimit Yu 豫 "province": 114

[Lüshi chunqiu, ch. 13 “Youshi lan”, § 1 “You shi” 有始:]

河漢之閒為豫 He Han zhi jian wei Yu

Between the He and the Han [rivers] there is $\mathrm{Yu}$ ["province"].

$\mathrm{Yu}$ "province" is found in all transmitted sets. In the Rong Cheng shi, Yu corresponds to $\mathrm{Xu}$ 敘 "province". ${ }^{115} \mathrm{Yu}$ covers the region of Luoyang, the Centre of the ideal picture of the world under the Zhou dynasty. In representations of the "Nine Provinces" within the framework of the $3 \times 3$ grid, Yu occupies the central square. ${ }^{116}$ The He and Han rivers, seen as boundaries of the central square of the $3 \times 3$ grid, divide the territory of the "Nine Provinces" into three equal thirds: the He River delimits the Centre from the North, and the Han River from the South (see Figure 3). In the "Shi di", the Han River is referred to from the other side, as the northern boundary of Jing "province" (another name of the Chu Kingdom), which occupies the southern square of the grid: ${ }^{117}$

\footnotetext{
113 The next level down in the hierarchy stays the same with the value of 3000 .

${ }^{114}$ Lüshi chunqiu (Sibu beiyao ed.), 13/2a.

${ }^{115}$ See Dorofeeva-Lichtmann 2010, p. 29. According to the "Shi yan” 釋言 chapter of the Er ya, Yu 豫 and $\mathrm{Xu}$ 敘 are synonims.

${ }^{116}$ For locations of "provinces", as given in the transmitted accounts, and the $3 \times 3$ grid, see DorofeevaLichtmann 2019 [rev. 2009], pp. 607-618.

${ }^{117}$ Er ya Guo zhu (Sibu beiyao ed.), 6/1b.
} 
[Er ya, ch.9 "Shi di”]

漢南曰荆州 Han nan yue: Jing zhou

[The territory] to the South of the Han River: Jing "province".

In the "Yu gong", the Han River is not used as a "province" boundary, but twice is mentioned in the description of Jing "province". If we accept that the Han River conventionally divides the mapped territory into equal northern and southern sections, then one must add another line of squares at the bottom or the South of the $3 \times 3$ grid:

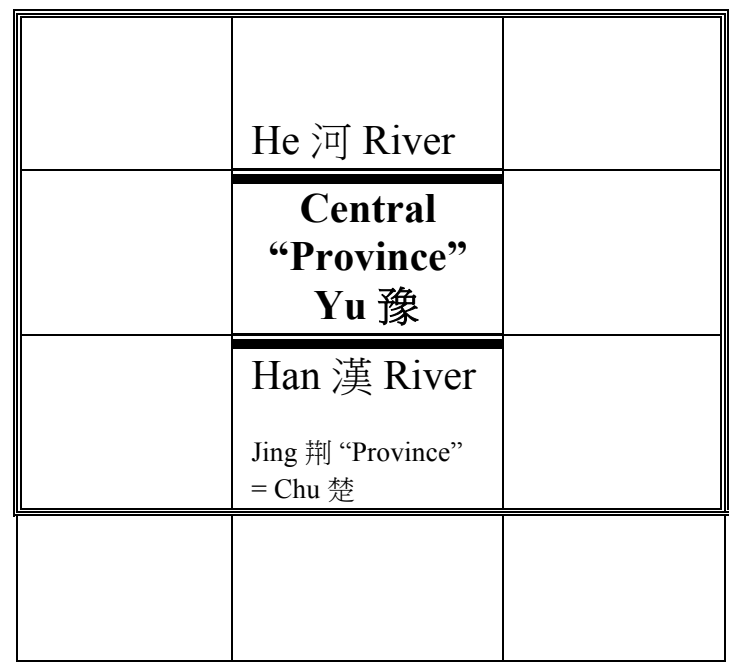

Figure 3: Positions of Yu and Jing "provinces" within the 3x3 grid representation of the "Nine Provinces" (delimited by a triple line)

This simple scheme demonstrates the great impact of the South-North division along the Han River. It implies the extension of the "civilised world" to the South and shifts its centre to the northern border of Chu. The scheme also demonstrates a $3 \times 3$ scheme for the "Nine Provinces", which by definition cannot be divided into two halves by rivers as boundaries between the "provinces". Rivers as boundaries between the squares of the $3 \times 3$ grid are described in the "Wang zhi", where they complement the cardinal limits of the "Nine Provinces": 118

[ $L i$ ji, chapter "Wang zhi"]

North $\rightarrow$ South

自恆山至於南河, 千里而近; Zi Henglshan zhi yu Nanhe, qianli er jin;

自南河至於江, 千里而近; Zi Nanhe zhi yu Jiang, qianli er jin;

自江至於衡山, 千里而遙. Zi Jiang zhi yu Hengshan, qianli er yao.

From Heng Mountain to the Southern He River, it is as close as $1000 \mathrm{li}$;

From the Southern He to the Jiang River, it is as close as $1000 \mathrm{li}$;

From the Jiang River to the Heng1 Mountain, it is as far as $1000 \mathrm{li}$.

${ }^{118}$ This passage precedes the description of the cardinally-oriented border-marks of the "Nine Provinces" in the "Wang zhi", discussed above and belongs to the same paragraph, see footnote 87 above. 
East $\rightarrow$ West

自東河至於東海, 千里而遙; Zi Donghe zhi yu Donghai, qianli er yao;

自東河至於西河, 千里而近; Zi Donghe zhi yu Xihe, qianli er jin;

自西河至於流沙, 千里而遙. Zi Xihe zhi yu Liusha, qianli er yao.

From the Eastern He to the Eastern Sea it is as far as $1000 \mathrm{li}$;

From the Eastern He to the Western He, it is as close as $1000 \mathrm{li}$;

From the Western He to the Flowing Sand, it is as far as $1000 \mathrm{li}$.

In the derived scheme the Jiang River takes the place of its confluent Han River, but the conveyed image is the same: a river or rivers in no way can divide the "Nine Provinces" into equal southern and northern parts (see Figure 4).

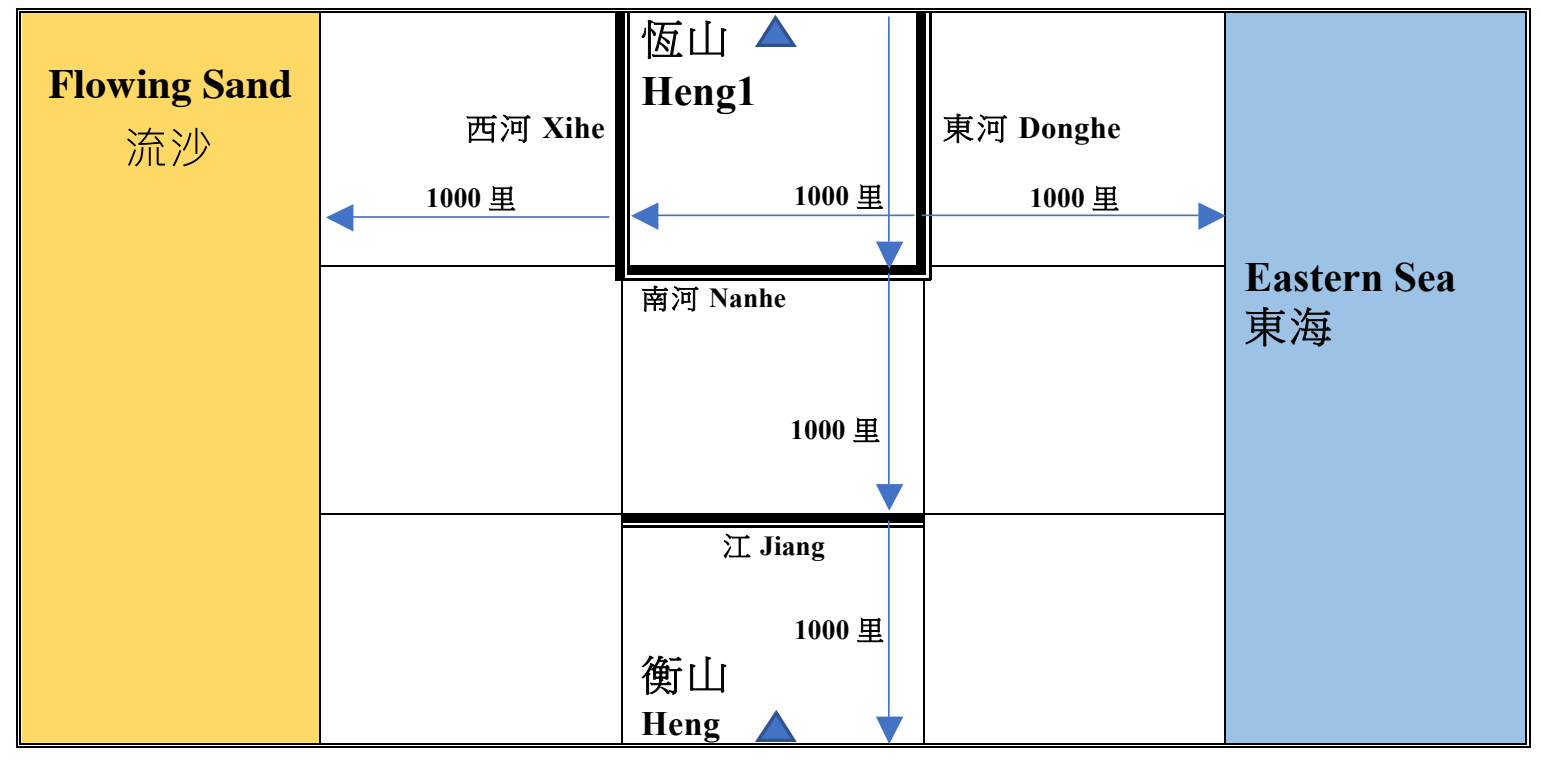

Figure 4: Borderlines and dimensions of the "Nine Provinces", according to the "Wang zhi" chapter of the $L i j i$

Figure 3 and $\mathbf{4}$ are reconstructions derived from texts, but similar dispositions of the boundary marks with respect to each other can be observed in authentic maps showing the topography of the "Nine Provinces", beginning from the earliest specimens drawn as commentaries to the "Yu gong". Since these maps include the whole set of landmarks related to the "Nine Provinces", they have a more complex configuration, but this configuration is still shaped by relative locations. The depiction of rivers in these maps mostly relies on the nine river routes, which, together with the nine land routes, supplement the description of the "Nine Provinces" in the "Yu gong". The delineation of rivers in the "Yu gong" has an interesting characteristic - parts of the same river may have different names. Thus, the Han River belongs to the fourth river route, which consists of the Jiang River with its northern tributary. Han is the name of the middle 
course of this northern tributary. The description of this northern tributary of the Jiang River, which constitutes the first part of the fourth river route, is as follows: ${ }^{119}$

[Shang shu, "Yu gong", Karlgren § 24:]

嶓冢導漾, 東流為漢, 又東為滄浪之水, 過三澨, 至于大別, 南入于江...

[Starting from] Bozhong [Mountain Yu] a way was made along the Yang, which flowing eastward became the Han [River], farther to the East became the Canglang River, passing through the Three Dykes, reached Dabie [Mountain], [and flowing] southward poured into the Jiang...

In Map 1, which is limited to the "Nine Provinces", depiction of the northern tribute of the Jiang River closely follows the "Yu gong", Han designating the middle course of the tributary. It is depicted closer to the bottom of the mapped area, and, therefore, does not work as a boundary between the southern and the northern halves. In Map 3, where the "provinces" are inscribed into a larger cartographical context, Han becomes the name of the entire northern tributary of the Jiang River. Here one can see that the Han River does indeed cut the mapped territory into approximately equal parts, but only by including territories to the South of the "Nine Provinces". One of the most interesting maps in this respect is the "Map of the Nine Provinces, the [nine itineraries marked by] mountains and the [nine] river [itineraries] of the Yu's [system of] Tribute" (Yugong jiuzhou shanchuan zhi tu 禹貢九州山川之圖) from the encyclopaedia on statecraft Diwang jingshi tupu 帝王經世圖譜 in 16 juan, by Tang Zhongyou 唐仲友 (1136-1188), see Map 4. This map shows thick borderlines between the "Yugong" "provinces", and adds a tenth similarly delimited region to the South of the "Nine Provinces" designated Southern Yue (Nan Yue 南越). Originally referring to a conglomerate of the southern Yue tribes, with the foundation of the Han dynasty Nan Yue became a name of a shortlived kingdom (204-111 BC) located to the South of the Nanling mountain range. In this map, the depiction of the northern tribute of the Jiang River deviates in some details from the "Yu gong", but its middle course still bears the name Han. It cuts the mapped territory into northern and southern halves, but only with this additional southern element. Curiously, in contrast to the "provinces" filled out by mountains and rivers, the Nan Yue is a blank territory. In this respect it is similar to the implied southern extension in the Rong Cheng shi, which is also devoid of any landmarks.

${ }^{119}$ Shangshu zhengyi (Sibu beiyao ed.), 6/15a-b. Translation is my own, cf. Legge, trans., 1865, pp. 136137 (§ 8); Couvreur, trans. 1897, p. 83 ( $§ 24)$; Karlgren, trans. 1950, pp. 16-17, § 24. The Han River occurs in the "Yu gong" two other times, in the description of the southern Jing "province" and both cases in relation to the Jiang River, see Legge, trans., 1865, pp. 112-116 (§ 46-53); Couvreur, trans., 1897, pp. $72-73$ ( $\S 12-13)$; Karlgren, trans. 1950, pp. 13 and 15 (§§ 13-14). 


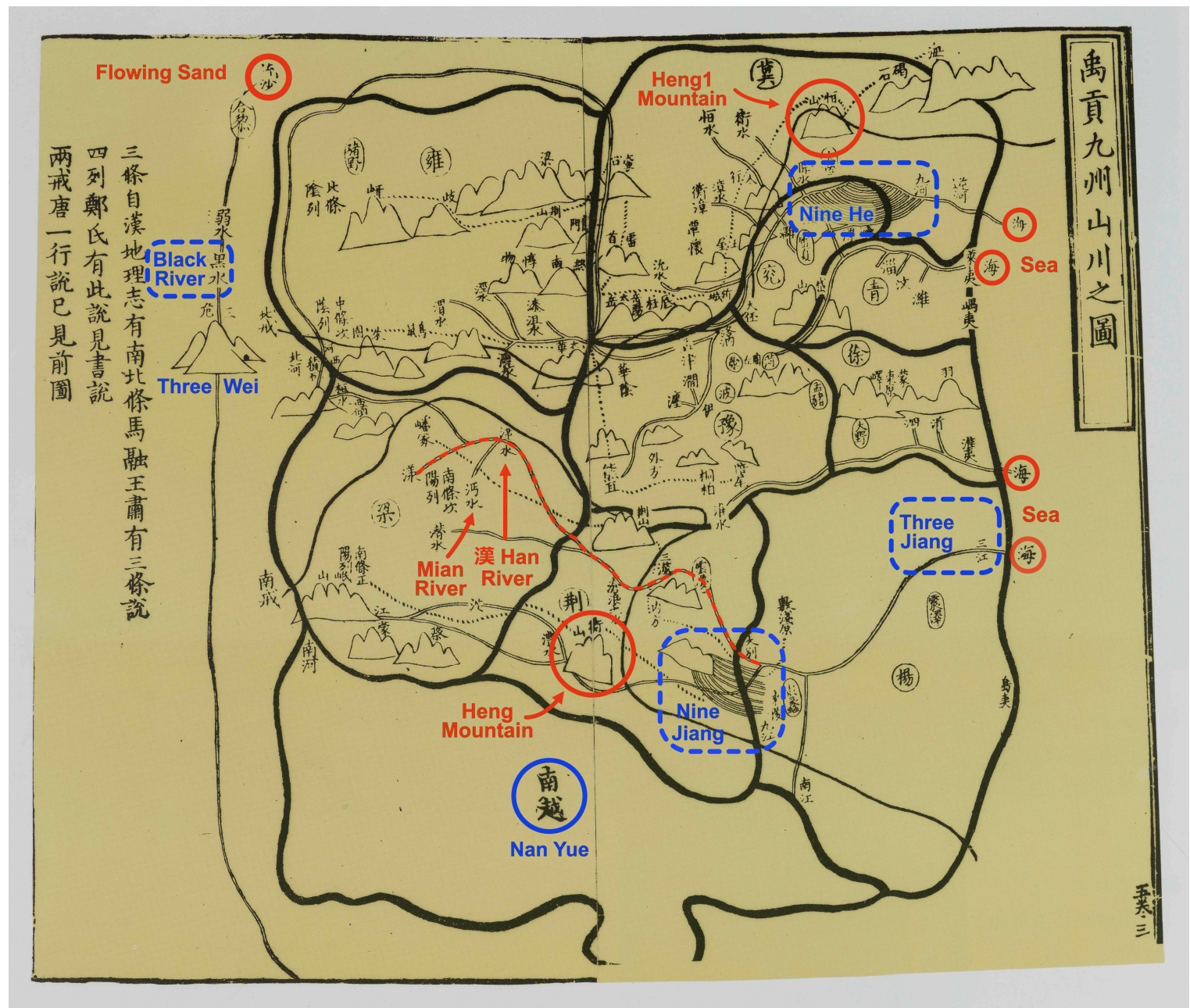

Map 4. "Map of the Nine Provinces, the [nine itineraries marked by] mountains and the [nine] river [itineraries] of the 'Yu's [system of] Tribute"' (Yugong jiuzhou shanchuan zhi tu-禹貢九州山川之 圖), in: encyclopaedia on statecraft Diwang jingshi tupu 帝王經世圖譜 in 16 juan, by Tang Zhongyou 唐仲友 (1136-1188). National Library of China (Beijing) 中國國家圖書館. [Reproduced from Yan Ping et al., 1998, p. 84]. Printed on two pages in a block-printed book, precise dimensions unavailable.

In modern Western maps, the Han River falls diagonally into the Jiang River from the North-West, but in the Song maps it is depicted more horizontally. In some traditional Chinese maps, the Han River forms an almost horizontal line with the Jiang River. This is the case with maps of China found in the so-called Sino-Korean atlases. Maps of China are overlooked in scholarly literature on the Sino-Korean atlases. The atlases are mostly known by their eye-catching first sheets, often referred to as the "wheel" maps. ${ }^{120}$ Although the atlases originate from the $16^{\text {th }}$ century, at the earliest, and

\footnotetext{
${ }^{120}$ For reference studies of these atlases and the "wheel" maps in English, see Nakamura Hirosi 1947, Ledyard 1994, Oh Sang-Hak 2008, Dorofeeva-Lichtmann 2019. The name "wheel map" was introduced by
} 
their numerous extant copies were made during the $18^{\text {th }}-19^{\text {th }}$ centuries, they are composed of strangely archaic maps. For reasons beyond the scope of this paper, the maps of China in the Sino-Korean atlases follow the patterns of the "Yu gong" maps from the Song dynasty. ${ }^{121}$ The maps also show the fifteen Ming provinces (sheng 省) curiously drawn over the "Yu gong" topography. The "Nine Provinces" and the fifteen Ming provinces are often distinguished by contrasting colours, which allow one to immediately grasp the difference in the areas they cover. The "Nine Provinces" keep to their traditional limits, the Ming provinces descend towards the sea in the South, see Map 5. The horizontally delineated Han-Jiang, Han here being the name of the entire tributary of Jiang, divides the mapped territory into equal southern and northern parts, if one takes into consideration the extended area in the South covered by the Ming provinces.

the famous Korean scholar Yi Ch'an in 1976, whose work became known to historians of cartography due to reference to it by Ledyard..

${ }^{121}$ I briefly discuss the maps of China in Dorofeeva-Lichtmann 2019, pp. 164-166. An indication of the late origins of these maps is the delineation of the lower part of the Yellow River: it flows South-East and pours into the sea below the Shandong Peninsula, having taken over the Huai River valley. This reflects the confluence of these two rivers, which existed between 1289 and 1853 (the schematic character of the map does not allow one to propose a more precise dating). In comparison, in Song dynasty maps the Yellow River flows North-East and pours into the Bohai Sea. 


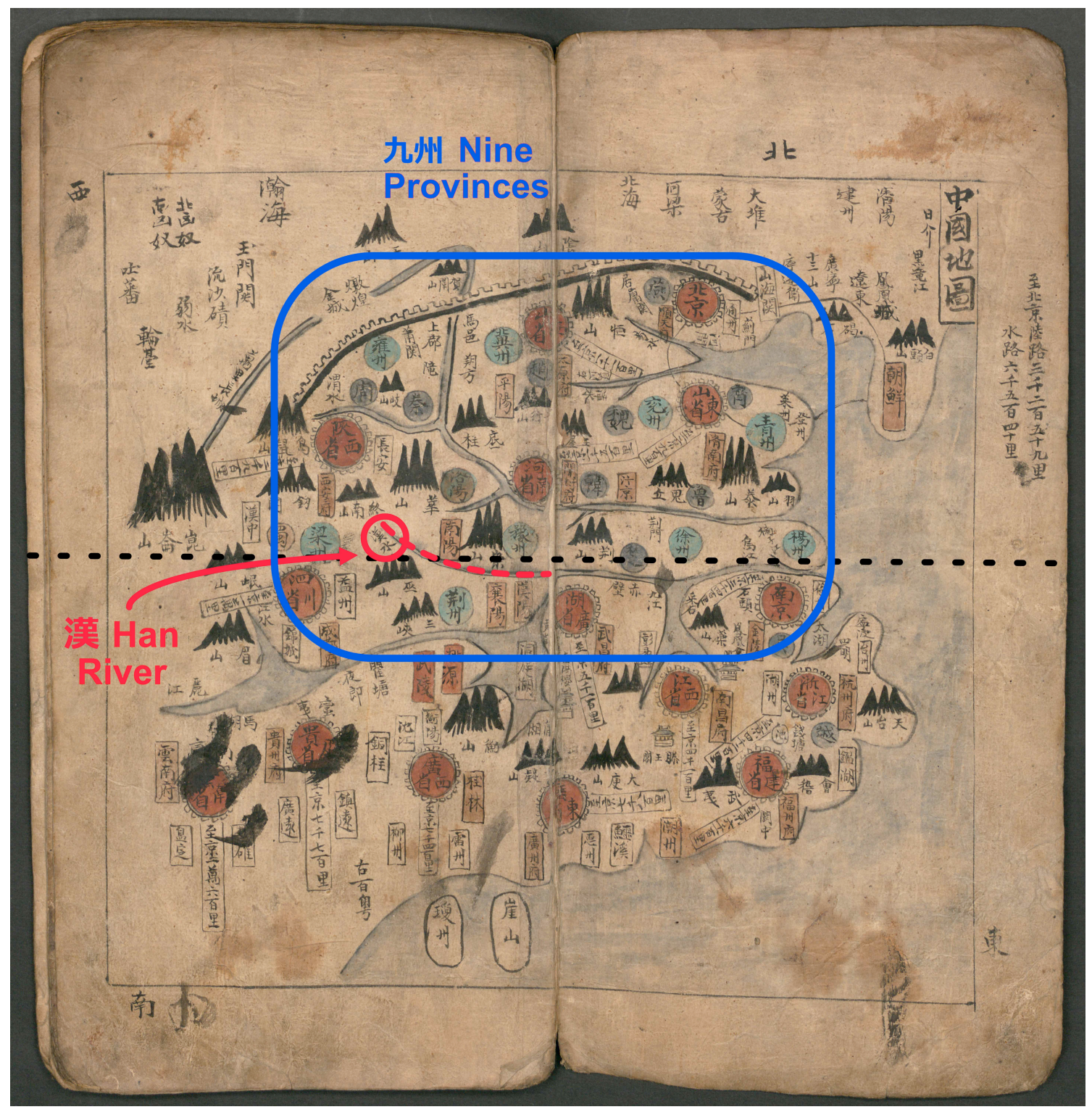

Map 5. Map of China, Sino-Korean Atlas [manuscript, coloured], Bayerische Staatsbibliothek, München, Germany

Shelfmark: Cod. cor. 72

https://daten.digitale-

sammlungen.de/0006/bsb00061455/images/index.html?id=00061455\&groesser=\&fip=eayayztsewqsdasqrssdasw $x$ dsyden eaya\&no $=10 \&$ seite $=12$

Printed on two pages in a block-printed book, precise dimensions unavailable.

Titles of the "Nine Provinces" (Jiuzhou 九州) are coloured in clear blue; titles of the 15 Ming provinces (sheng 省) are coloured in faded red; in both cases the titles are inscribed inside circles

Few early Chinese texts describe southern territories beyond the Chu Kingdom, one of them is the Shanhai jing. This text was compiled by the end of the Former Han dynasty and conveyed the idea of terrestrial space of the united empire, the territory of 
which now extended towards the sea in the South. The Shanhai jing conveys an ideal organisation of terrestrial space characterised by a complex, yet regular structure. The nucleus of this structure is the arrangement of 447 mountains into 26 itineraries, each delineated as moving from mountain to mountain. The 26 itineraries are orderly distributed between the cardinal directions and the centre ( 3 itineraries in the North and the South, 4 in the East and the West, 12 in the Centre). ${ }^{122}$ The description of the $3^{\text {rd }}$ Itinerary of the Southern Mountains, in particular the directions and destinations of its rivers, reveals an extension of the mapped territory towards the sea in the South: the $3^{\text {rd }}$ itinerary of the Southern Mountains is delineated from the West to the East - parallel to the southern coast; the three rivers, which pour from the mountains of this itinerary (mountains $\mathrm{N}^{\circ} 2, \mathrm{~N}^{\circ} 9$ and $\mathrm{N}^{\circ} 13$, out of the total number of 13 mountains in this itinerary) flow to the South or to the South-East in the last case and pour into the sea.

The Han River is mentioned 5 times in the Shanhai jing:

- twice in the $1^{\text {st }}$ Itinerary of the Western Mountains $\left(\mathrm{N}^{\circ} 13\right.$ and $\mathrm{N}^{\circ} 14$ of the total number of 19 mountains in this itinerary); the river, which pours from mountain $\mathrm{N}^{\circ} 13$, flows to the South and pours into the Han River, and mountain $\mathrm{N}^{\circ} 14$ is the source of the Han River, which flows SouthEast and falls into the Mian 婳 River; ${ }^{123}$

- $\quad$ once in the $4^{\text {th }}$ Itinerary of the Western Mountains ( $\mathrm{N}^{\circ} 18$ of the total number of 19 mountains of this itinerary); the river of this mountain flows to the West and eventually pours into the Han River);

- twice in the $11^{\text {th }}$ Itinerary of the Central Mountains, which belongs to the southern group of the central itineraries (from the $8^{\text {th }}$ to the $12^{\text {th }}$ of the total of 12 central itineraries). The river which starts from mountain $\mathrm{N}^{\circ} 1$ of its 48 mountains flows to the South-East, and the river which starts from mountain $\mathrm{N}^{\circ} 10$ flows to the South; both rivers pour into the Han River.

No authentic maps or schemes of the system of the 26 itineraries have survived, and it is doubtful they ever existed. ${ }^{124}$ Wang Chengzu attempted to reconstruct a survey

\footnotetext{
${ }^{122}$ I have discussed the representation of space according to the Shanhai jing in a series of articles, see Dorofeeva-Lichtmann 1995, 2003a, 2003b, 2007. For a brief summary of this conception of space, see idem, 2015, pp. 103-112.

${ }^{123}$ The location of the Mian River is not clear. In the "Yu gong" it occurs only once - among water landmarks of the south-western Liang "province", where the Han River is not mentioned, see Shangshu zhengyi (Sibu beiyao ed.) 6/11a; Legge, trans., 1865, p. 123 (§ 40); Couvreur, trans. 1897, pp. 77 (§ 17); Karlgren, trans., 1950, pp. 15-16 (§ 17). In the "Yu gong" there is no evidence of any relation between the Mian and the Han, which is reported in the Shanhai jing. However, in the Shanhai jing the Mian River occurs only one other time, as a river into which falls the Motu 末塗 River, which pours from mountain $\mathrm{N}^{\circ} 10$ of the $1^{\text {st }}$ Itinerary of the Eastern Mountains. There is no other information about the Mian River in the Shanhai jing. Yet, in the maps showing the "Yu gong" topography, the Mian River is depicted in relation to the Han, but in different ways. E.g. in Map 1a the Mian and the Han are successive parts of the same waterway; in Map 4 the Mian River is the southern tributary of the Han.

${ }^{124}$ Dorofeeva-Lichtmann 2007.
} 
cartographical representation of the itineraries further developed by Richard Strassberg and myself, see Map 6. ${ }^{125}$ In addition to putting in evidence spatial arrangement of the itineraries, the map also allows one to see that the relational topography of the Shanhai jing has interesting differences from that of the "Yu gong". For instance, Heng Mountain, the marker of the southern limits of the "Nine Provinces" is duplicated; Heng1 恒 Mountain, the marker of the northern limit of the "Nine Provinces", is mentioned once as "being observed from distance" (wang 望) in the East from mountain $\mathrm{N}^{\circ} 7$ of the $3^{\text {rd }}$ Itinerary of the Western Mountain, where it precedes Kunlun Mountain, but is missing in the itineraries of the Northern Mountains or anywhere else in the text, even under its alternative name Chang 常.

\footnotetext{
${ }^{125}$ Wang Chengzu 1988 [rev. 1982], p. 19 (Map 2). Strassberg translates and completes Wang's reconstruction 2002, p. 37 (fig. 10). I have proposed some amendments, see Dorofeeva-Lichtmann 2003a, pp. 38 and 43; 2005-2006, p. 82. In Map 6 I have further corrected the source and the flow of the Han River.
} 


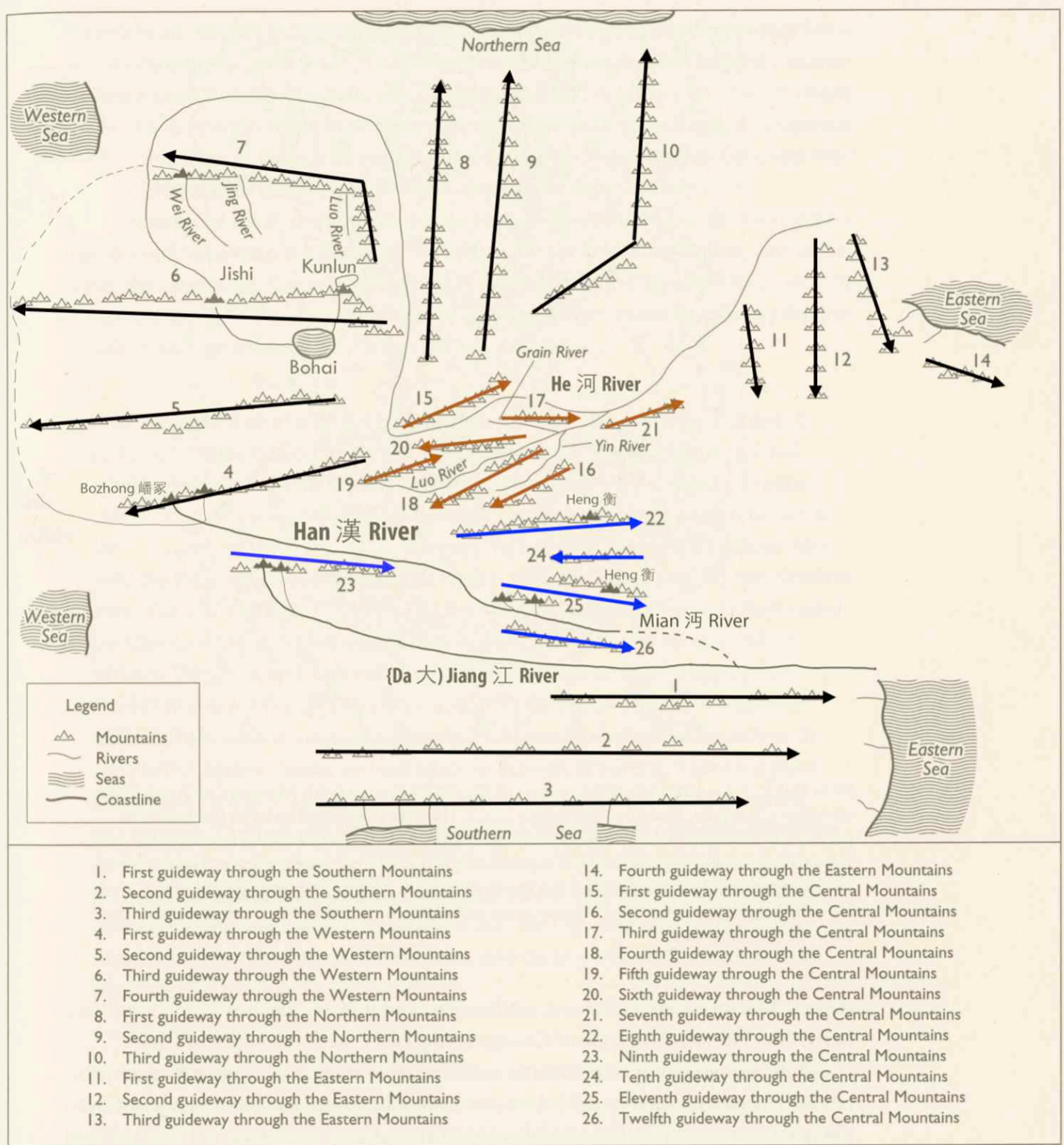

\begin{tabular}{|c|c|c|}
\hline Map 6. The Han & $n$ the system of itin & of the "Shan jing”" 山經 \\
\hline System of 26 itine & in the "Shan jing", & ding to its sequence of cardinal directions: \\
\hline 1. South & 3 itineraries directe & ward \\
\hline 2. WEST & 4 itineraries directe & ward \\
\hline 3. NORTH & 3 itineraries directe & hward \\
\hline 4. EAST & 4 itineraries directe & hward \\
\hline 5. Center & 12 itineraries direc & tward or westward, which constitute two clusters: \\
\hline & CENTER A & 7 itineraries in the Yellow River basin \\
\hline & Center B & 5 itineraries in the Yangzi River basin \\
\hline
\end{tabular}


Although the reconstruction of the system of relational topography of the Shanhai jing needs to be elaborated on further, it does reveal that in the Shanhai jing the Han River plays only a modest role. ${ }^{126}$ It does not work as a demarcation line that cuts the mapped territory into two equal halves: only five itineraries of the total number of twenty-six are located to the South of the Han River. In effect, the position of the Han River in the system of itineraries is quite similar to its position in the "Yu gong" family of the "Nine Provinces" - it delimits one third of the mapped territory in the South.

Nevertheless, a division of terrestrial space into northern and southern halves is implicite in the arrangement of the twelve itineraries of the Central Mountains into two clearly distinguishable clusters. As one can see from Map 5, the first seven itineraries of the Central Mountains form a structurally complete group around the central part of the Yellow River; the last five itineraries belong to the Yangzi River basin. ${ }^{127}$ However, the survey of terrestrial space in the Shanhai jing aims to attenuate the opposition between the North and the South, and not to emphasise it.

The division of terrestrial space into the North and the South does not seem to play an important role in the corpus of pre-Han early texts. One can rather speak of a predominance of the North, as is the case in the transmitted descriptions of the "Nine Provinces" of the "Yu gong" group. An earlier example of this northern predominance is the representation of terrestrial space mapped out by the "Guo feng" 國風 chapter (literally "The Airs of Principalities", ca. 8th-6th centuries) of the Shi jing 詩經 ("The Book of Songs"). The structure of the "Guo feng" is underlied by an ideal scheme of Zhou principalities. It starts with positioning the South: its first two groups of songs share a common name including "South", the “Zhou nan” (周南) and the "Shao nan" (召 南). In this respect they formally differ from the other thirteen groups of songs, which constitute the main part of the "Guofeng”, each named feng 風 (“air"). The "Airs" bear the names of Zhou principalities, all located in the Yellow River basin. ${ }^{128}$ Their positioning as the North is signaled by the name of the first "Air" - Bei 非, which includes the phonetic "North" (bei 北), and which in the manuscript version of the Shi jing, discovered at Shuanggudui (隻隻古堆) near Fuyang 阜陽, is written simply as "North".

\footnotetext{
${ }^{126}$ In comparison, the Jiang 江 River(s) is mentioned 15 times, in the $1^{\text {st }}$ itinerary of the Eastern Mountains, $9^{\text {th }}$ and $12^{\text {th }}$ itineraries of the Central Mountains.

${ }^{127}$ The reference to the Yellow or the Yangzi rivers basins is determined by the destination of rivers, which pour from the mountains along the itineraries. The "northern" cluster of the Central Mountains contains seven itineraries and the "southern", five itineraries, but their inequality in the number of itineraries is compensated for by a greater number of mountains in the southern group of itineraries, see Dorofeeva-Lichtmann 1995, 91, table 2.

${ }^{128}$ Dorofeeva-Lichtmann 1991.
} 
An interesting phrase, fen bei sanmiao 分北三苗 (“demarcated the North from the Three Miao"), concludes Shun's deeds in the "Shun dian" (Karlgren: "Yaodian 2"). ${ }^{129}$ However, no details about this spatial arrangement are provided, apart from a reference shortly before that the Three Miao were transferred to the Three Wei 三危, which in the "Yu gong" topography is located to the West of the "Nine Provinces". 130 One can suggest, that, in this case, the territories governed by Shun are understood as being under the term the "North", the demarcation thus rather means "distinguishing the North", and not drawing a borderline between North and South.

In sum, from the perspective of the early Chinese written tradition, the statement on the division of terrestrial space into two equal halves along the Han River, concluding the description of the "Nine Provinces" in the Rong Cheng shi, is absolutely revolutionary. The Han River is a landmark that plays a secondary role in transmitted descriptions of the "Nine Provinces" and was firmly associated with Chu territory. In the Rong Cheng shi, the Han River becomes the central axis and radically changes the picture of terrestrial space mapped out by the "Nine Provinces": the centre is shifted to the northern border of the Chu Kingdom, and the southern limits are thus pushed farther to the South. The northern extension of territories covered by the "provinces" becomes outbalanced by the implied extention to the South.

The Han River, however, may play a role of a demarcation line, or, according to David W. Pankenier, a "cosmographic divide", not on the terrestrial surface, but in its projection onto celestial space: the toponym Han occurs in two of three names of the Milky Way used in early Chinese texts - literally the "Heavenly Han" (Tian Han 天漢) and the "Han [Beyond] Clouds" (Yun Han 雲漢). ${ }^{131}$ The Milky Way roughly divides celestial space into two halves. The earliest surviving celestial map clearly showing the Milky Way is drawn on the ceiling of a Northern Wei (386-534 AD) tomb in Luoyang's

\footnotetext{
${ }^{129}$ Shangshu zhengyi (Sibu beiyao ed.), 3/17a. Cf. interpretation by Legge, trans. 1865, p. 50 (§ 27), Couvreur, trans. 1897, p. 31 (§ 27); Karlgren, trans. 1950, pp. 6 and 8 (§38).

${ }^{130}$ Shangshu zhengyi (Sibu beiyao ed.), 3/8b; Legge, trans. 1865, pp. 39-40 (§ 12); Couvreur, trans. 1897, p. 22 (§ 12), Karlgren, trans. 1950, pp. 5-6 (§ 23). In the "Yu gong" the Three Wei are mentioned together with the Three Miao in the description of the western "province" Yong 雍 (Shangshu zhengyi, Sibu beiyao ed., 6/12a, Legge, trans. 1865, pp. 123-127 (§ 10); Couvreur, trans. 1897, pp. 78-81 (§ 18-19); Karlgren, trans. 1950, pp. $15-17$ (§ 18-19)), while only the Three Wei are mentioned in the description of the Black River, which corresponds to the second river route (Shangshu zhengyi, Sibu beiyao ed., 6/14b; Legge, trans. 1865, p. 132 (§ 2); Couvreur, trans. 1897, p.82 (§ 22); Karlgren, trans. 1950, pp. 16-17 (§ 22)). In maps of the "Yu gong" topography the Three Wei are depicted at the western border of Yong, e.g. in Map 1a it appears as a toponym without any cartographic image, while in Map 4, a rare case showing borders between "provinces", the Three Wei are depicted as an outstanding mountain with three summits along the Black River course and located outside the western border of the "Nine Provinces".

${ }^{131}$ References to the Milky Way in early Chinese sources and their representations in celestial cartography are discussed throughout the book by Pankenier 2013.
} 
洛陽 Mengjing 孟津 county. This coloured mural map depicts the Milky Way as a wide river tinted in blue and filled out with wavy lines imitating flowing water. It divides the celestial circle along its diameter from North to South, so that the celestial space becomes devided into the eastern and the western halves, see Map $7 \mathbf{a , b}{ }^{132}$

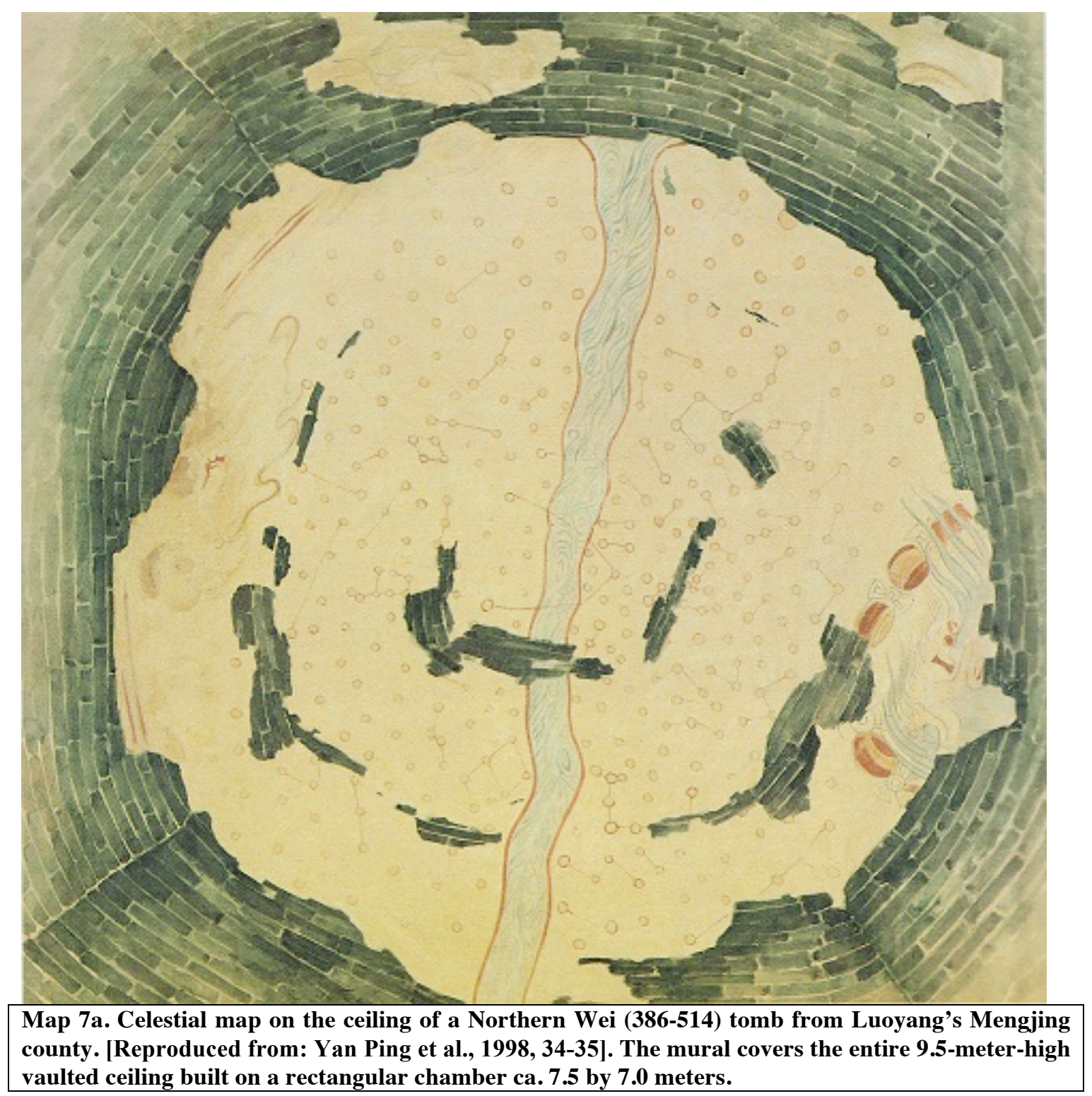

${ }^{132}$ For a study of this map in the context of Chinese cosmology, see Lilian Lan-ying Tseng 曾藍瑩 (2003). The map contains clearly depicted graphic symbols - recognisable constellations, single stars and the Milky Way dominating the entire picture, but no text, so it is not possible to determine which term may have been used to designate the Milky Way. This map is not discussed by Pankenier; in later maps discussed in his study the depiction of the Milky Way becomes more refined and crosses celestial space from the North-West to the South-East. 


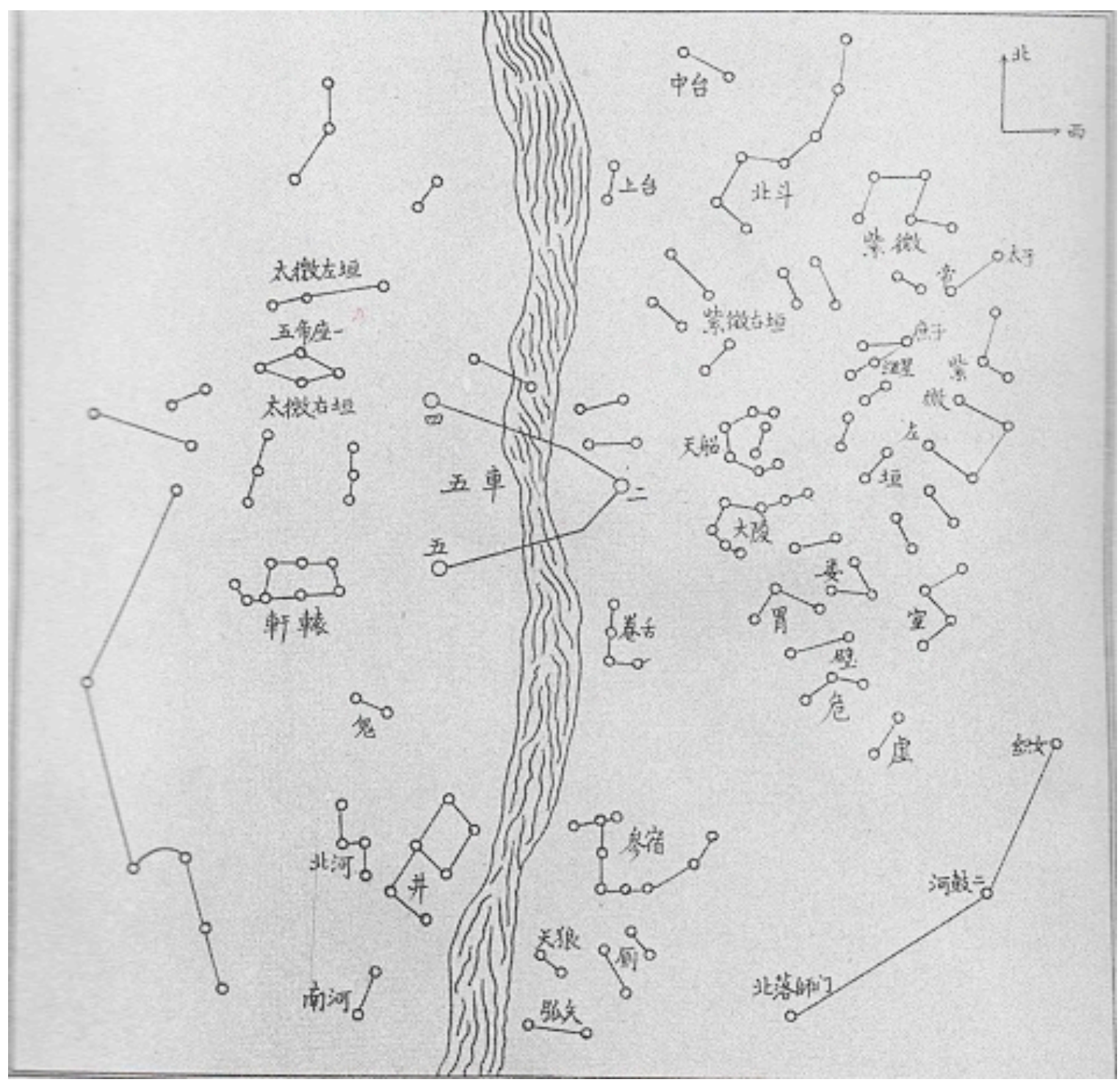

Map 7b. Redrawing of the celestial map on the ceiling of a Northern Wei (386-514) tomb from Luoyang's Mengjing county with added names of constellations. North is on top, West is on the right (view from the Earth). Redrawing made at the National Museum of China (Beijing). Dimensions of the original unavailable. [Reproduced from: Yan Ping et al., 1998, 34-35]

Although, according to Pankenier, the Milky Way is assumed to be "functionally identical in astrological terms" to the Yellow River, which indeed appears in the third possible name of the Milky Way - the Silverly He (= Yellow River, Yin He 銀河), the usage of the toponym Han in its name still links it closely with the Han River, and this link cannot be ignored. ${ }^{133}$ Moreover, the name Silvery He becomes current after the fall

\footnotetext{
${ }^{133}$ Pankenier 2013, pp. 276-279 ("The Sky River as cosmographic divide"), especially note 35 on page 276. Despite the pertinance of Pankenier's study, he misleadingly does not distinguish these two different
} 
of the Han dynasty, while earlier transmitted texts more commonly use Han when referring to the Milky Way. For instance, in the Shi jing, the Milky Way is mentioned three times, once as the Heavenly Han ("There is the Han [River] in the Sky" - wei tian you Han 維天有漢) in the poem “The Great East” (Da dong 大東, no. 203) of the "Xiao ya" 小雅 section, and twice the Han [Beyond] Clouds in a poem under the same name Yun Han (no. 258) and in the “Oak-wood unworked” (Yu pu 棫樸, no. 238), both from the "Da ya" 大雅 section. ${ }^{134}$ It is possible then to suggest that the division of mapped territory into two halves along the Han River in the Rong Cheng shi may evoke or even be inspired by celestial topography, as an application of the principle of the Heaven-Earth correlation. ${ }^{135}$ Since no celestial issues are discussed in this manuscript, however, the only argument in favour of this hypothesis is the structural similarity between celestial and terrestrial spaces cut in two by a Han River.

\section{Yu's handling of tools and wearing out of his body}

The immediate context of description of the "Nine Provinces" in the Rong Cheng shi includes one more point, which at first sight does not have direct relation to conceptualising terrestrial space - Yu's personal and exhausting physical engagement in hard work. It follows the passage on Yu's appointment for regulating disordered landscape and becomes interwoven with the description of the first pair of "provinces" (slips 23-15=24-25). Although slips 15 and 24 (most likely pieces of a single slip) are considerably damaged, the main idea of the introduction is clear: Yu's extraordinary austerity and exceptional diligence: ${ }^{136}$

river toponyms for designating the Milky Way and translates both as simply "river":- the Sky River (Tian Han), the River of Clouds (Yun Han) and the Silvery River (Yin He), see ibid, p. 396.

${ }^{134}$ Apart from these occurrences, the terrestrial Han River appears in four other poems, always together with Jiang: 4 occurrences in the poem "Han is broad" (Han guang 漢廣, no. 9) of the "Zhou nan" 周南 group, the "Guo feng" 國風 section), one in the "4th Month" (Si yue 四月, no. 204) of the "Xiao ya" section, 3 occurrences in "Jiang [and] Han" 江漢 (no. 262) and the "Ever-Martial” (Chang Wu 常武, no. 263), both the "Da ya" section. As in the case of the Shanhai jing, occurrences of the rivers He and Jiang are much more frequent. For the variation in the mountain name, see Nienhauser, ed., 1994, pp. 23-24, footnote 27.

${ }^{135}$ Correlation between celestial and terrestrial space - Fen ye 分野 - is not a simple projection of one surface on another, but a complex system of correspondences, see the "Principles of field-allocation astrology" and "Derivation of relevant astrological correspondences" in Pankenier 2013, pp. 268-273 and pp. 273-276, respectively.

${ }^{136}$ Translations of this considerably damaged part of the manuscript by Pines, 2010, pp. 9-10, and Allan, 2015, pp 203-204 and pp. 239-241, differ in some details, but not in general sense. Yu's modesty in clothing, which can be made out from slip 15, is difficult to explore due to its damaged state. Yu's austerity is also described in the much better preserved slips 20-21, see Pines, 2010, p. 13, and the extensively commented translation by Allan, 2015, pp. 207-211and pp. 247-248. 
[Rong Cheng shi, slips 23-15=24-25:]

…禹既已 [end of slip 23; beginning of slip 15:] 受命.

乃卉(=草)服箁箬帽. Pines: 芙口足口 $\square$... / Allan: 芙蓻 $\square$ 足 $\square$...)

[break of slip 15; break of slip 24, now considered to be parts of a single slip]

Pines: $\square$ 面乾粗, 脛不生之毛 ${ }^{137} /$ Allan: 面乾, 蹠垢, 不生肢毛.

Pines: $\square$ /Allan: 剴濏(=開塞)湝流.

禹親執枌(=未 未i Ling, Qiu Dexiu/ 畚 Chen Jian et al.)䇃(=耛);

以波 (=陂) 明者(=都) 之澤;

決九河 [end of slip 24; beginning of slip 25:] 之枚 (=阻 Li Ling et al. ; =泄 Xu Quansheng).

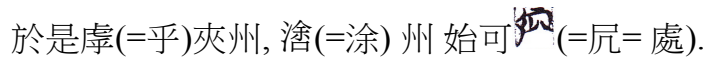

Yu ji yi shou ming,

nai huifu, pei(?)ruo mao, Pines: $f u X X z u$ X/Allan: $f u$ zhi $X z u X$ Pines: $X$ mian gancu, jing bu sheng zhi maol

Allan: Miangan, zhihou, bu sheng zhi mao.

Kai qin(?) jie liu.

Yu qin zhi fensi;

Yi bo Mingdu zhi ze;

Jue Jiuhe zhi(?)

Yushihu Jiazhou, Tuzhou shi ke chu.

Once $\mathrm{Yu}$ had received the appointment,

[he] then dressed in clothing made of grass/bamboo leaves, a bamboo hat, and plant footwear on his feet

(?)

[break of slip 15 ; break of slip 24]

Pines: His face became dry and coarse, his shin was that of not producing hair. /

Allan: His face was chapped, his footsoles filthy, did not produce limb hair.

[he] opened the blocked [ways] and drained the water.

$\mathrm{Yu}$ personally held the plough handle (Li Ling)/bamboo or wicker scoop (Chen Jian) and the ploughshare; In order to dike the Mingdu Marsh;

[and] released the blockage (Li Ling et al.)/(leak - Xu Quansheng) of the Nine He [rivers];

Thereupon Jia "province" [and] Tu (=Xu) "province" first became habitable.

The concept of Yu's employement of agricultural tools in order to regulate waters, sometimes to the extent of exhausting his body, is found in a series of late Warring States - Former Han texts. To begin with, according to the quotation of Mozi in the "Tianxia" chapter of the Zhuangzi, referred to above, Yu's regulation of waterways is the direct outcome of his personal use of tools:

["Tianxia" chapter of the Zhuangzi citing the Mozi:]

禹親自操手䎤而九雜天下之川 ... Yu qin zi cao tuosi er jiu za Tianxia zhi chuan...

$\mathrm{Yu}$ personally himself operated the sack/basket [for collecting soil] and ploughshare and [thus within] the Nine [Provinces] interlaced the rivers of the Under-heaven...

${ }^{137}$ Pines refers to Su Jianzhou, 2003, p. $136(\S \S 28-29)$. 
Similar passages are found in the “Wu du” 五蟗 (“Five Vermins") chapter of the Han Feizi 韓非子, the “Lüe yao” 略要 (“An Overview of the Essentials”) chapter of the Huainanzi and in the “Sima Xiangru liezhuan”司馬相如列傳 (“Memoir on Sima Xiangru") of the Shi ji 史記. The passage from the "Wu du" chapter is distinguished by the listing of notable attributes of the worn-out state of Yu's body due to his personal use of tools - emaciated thighs and hairless shins - as well as pointing out the extreme strenuousness and the seemingly low status of his physical work. There is also another interesting nuance - it was this personal wielding of the tools that enabled $\mathrm{Yu}$ to become the ruler: ${ }^{138}$

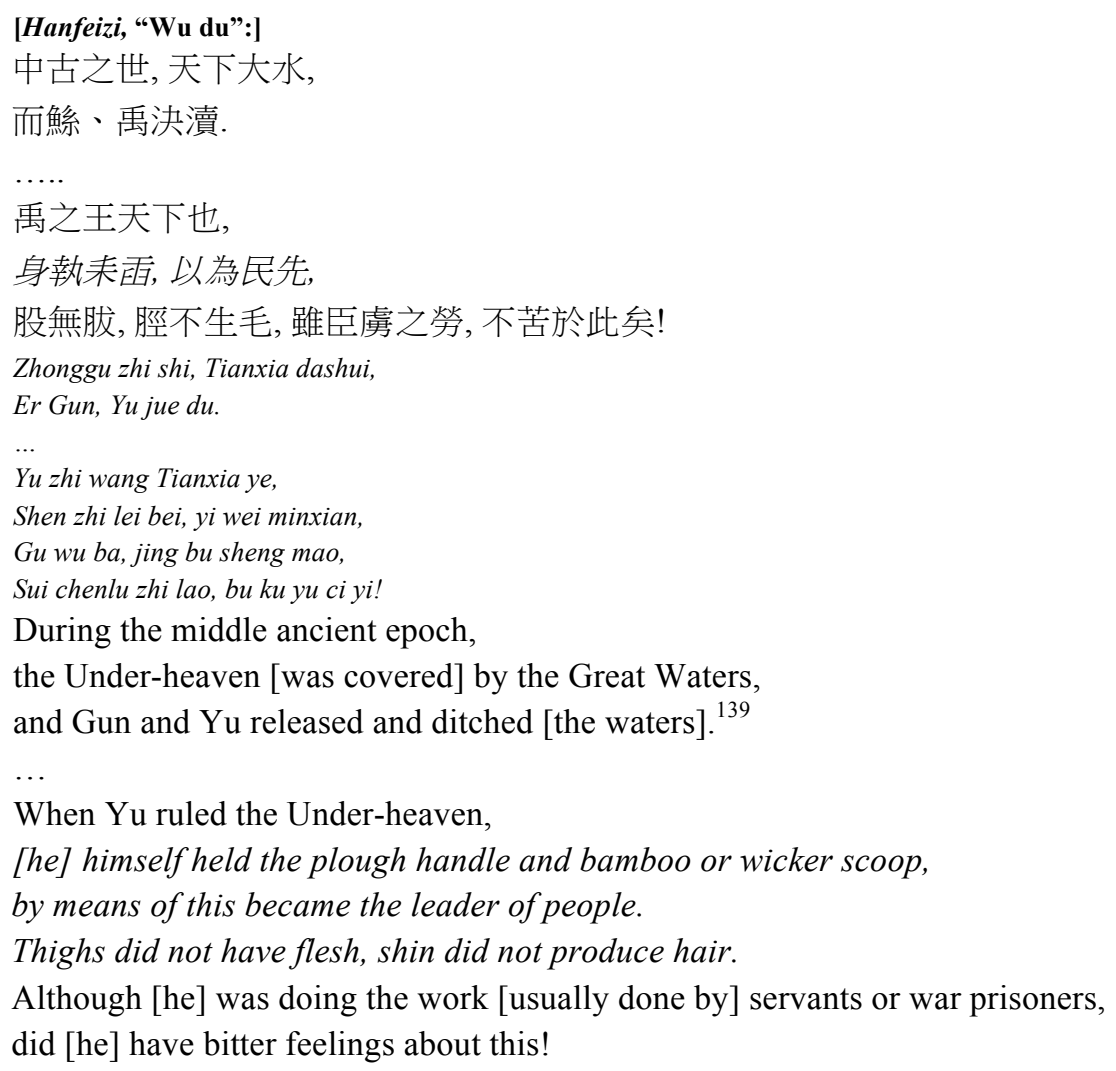

The passage from the "Lüe yao" chapter, with a slight difference in specific tools applied by $\mathrm{Yu}$, copies the point about the role of his personal handling of tools for becoming the ruler. The passage omits details about damages to his body and exceptional hardship of his work, but instead develops on attributes of regularity of the main waterways put in order by means of the tools: ${ }^{140}$

${ }^{138}$ Hanfeizi jishi 韓非子集釋 1974, p. 1041; Wen-kwei Liao, tr., 1959, p. 277; Burton Watson, tr., 1964, pp. 97-98. My translation differs is some details.

${ }^{139}$ This passage mentions Gun and Yu together "releasing" (jue 決) the Floodwaters. Compare with n. 99 above.

${ }^{140}$ Huainan honglie jijie, 709; Major et al., The Huainanzi, 864. My translation differs in some details. 


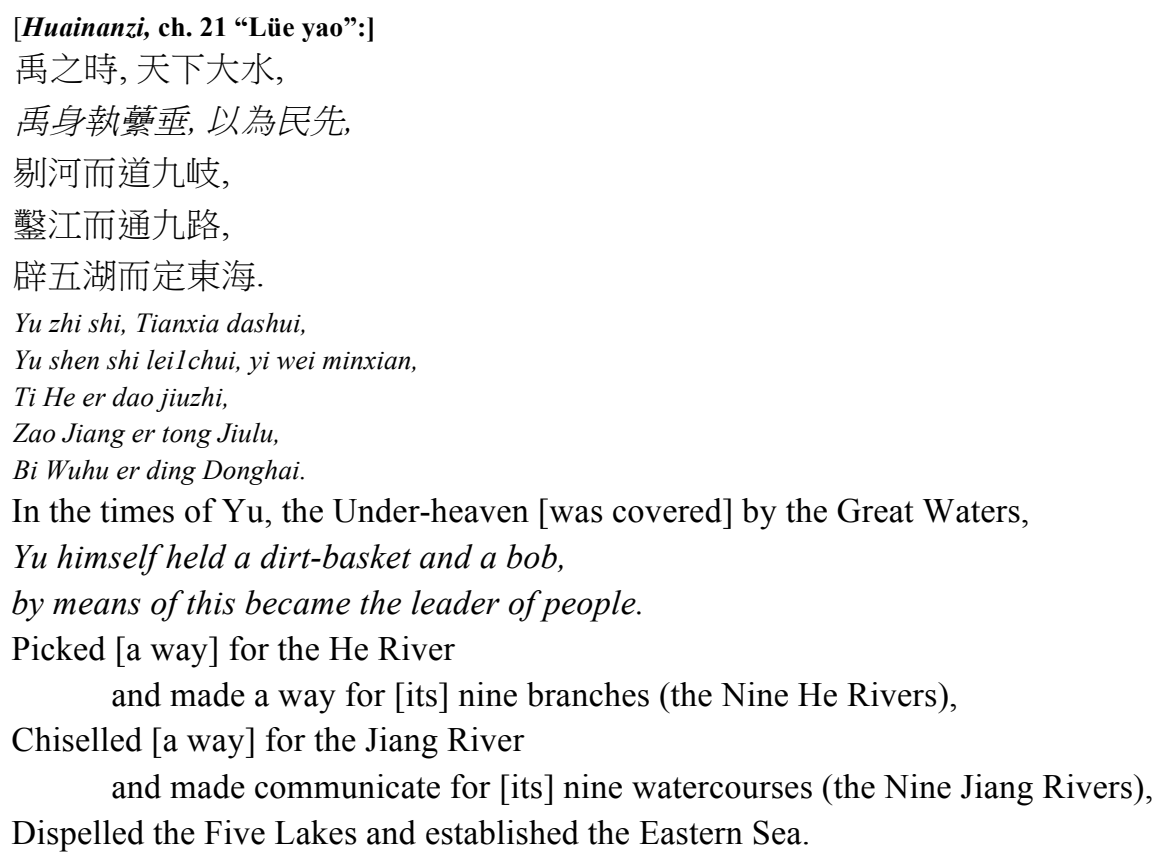

The attributes of the regularity of the system of waterways in the "Lüe yao" evoke three water landmarks of the "Nine Provinces" - the Nine [branches of the] He River, the Nine Jiang rivers, and the Five Lakes, which are quantitatively arranged by numerologically significant numbers conveying the idea of order. ${ }^{141}$ In the Lüshi chunqiu, in the "Zhongxia ji” 仲夏紀 ("Middle Summer Records") chapter of the "Shier ji” section and the "Kai chun" ("Beginning of Spring") chapter of the "Six Discourses" section, one finds less structurally perfect, but still quite similar summaries of Yu's rearrangement of the major waterways, and also references to his exceptional diligence in draining the excess waters, but without naming specific tools or attributes of the wornout state of his body: ${ }^{142}$

${ }^{141}$ For the Nine [branches] of the He River and and Nine Jiang Rivers, see footnote 82 above. The Five Lakes are either identified with Taihu Lake or with the system of lakes along the lower and middle parts of the Yangzi.

${ }^{142}$ Lüshi chunqiu (Sibu beiyao ed.), 5.9b-10a; Wilhelm, tr., 1928, p. 65; Kamenarovic, tr., 1998, p. 95; Knoblock and Riegel, tr., 2000, pp. 149-150 (§ 5/5.10), Tkachenko, tr., 2001, p. 116; and Lüshi chunqiu (Sibu beiyao ed.), 21.8a; Wilhelm, tr., 1928, p. 383; Kamenarovic, tr., 1998, pp. 423-424; Knoblock and Riegel, tr., 2000, p. 561 (§ 21/5.3), Tkachenko, tr., 2001, pp. 364-365, respectively. A similar passage on Yu's managing waterways, but without mentioning his physical exhaustion is found further, in the "Eight Observations” (Ba Lan 覽) section, ch. 15 “Shen da lan” 慎大覽 (“Observations on Being Careful about the Great”), §7 “Gui yin” 貴因 (“Valuing the Moment”): 禹通三江、五湖, 決伊閭, 溝迴陸, 注之東 海, 因水之力也 “Yu made communicate the Three Jiang and the Five Lakes, released jams and congestions, [made] drainage ditches to circumnavigate the pieces of land, and poured them into the Eastern Sea, [only] relying on the [natural] force of the water [to flow down]", see Lüshi chunqiu (Sibu beiyao ed.), 15.15b; Wilhelm, tr., 1928, p. 227; Kamenarovic, tr., 1998, p. 269; Knoblock and Riegel, tr., 2000, p. 364 (§ 15/7.1); Tkachenko, tr., 2001, p. 235. 
[Lüshi chunqiu, ch. 5 “Zhongxia ji”, § 5 “Gu yue” 古樂 (“Music of the Ancients”):]

禹立，勤勞天下，日夜不解，

通大川，決雍塞，鏧龍門，降通漻水以導河，疏三江、五湖，注之東海.

Yu li, qinlao Tianxia, riye bu xie,

tong da chuan, jue yongsai, zao Longmen, jiang tong liao(?) shui yi dao He, shu Sanjiang Wuhu, zhu zhi Donghai.

When $\mathrm{Yu}$ took the position of the ruler, he diligently tired [himself] for the Under-heaven, day and night did not relax, made communicate big rivers, released obstructions and blockages, ${ }^{143}$ descended and made communicate unruly(?) waterways in order to make the way of the He [River], separated the Three Jiang and the Five $\mathrm{Hu}$, made them pour into the Eastern Sea.

[Lüshi chunqiu, ch. 21 “Kai chun”, § 5 “Ai lei”愛類 (“Appreciating the Same Class”)]

昔上古龍門未開, 吕梁未發, 河出孟門, 大溢逆流, 無有丘陵沃衍、平原高阜, 盡皆滅之

, 名曰鴻水。禹於是疏河決江, 為彭蟲之障, 乾東土, 所活者千八百國, 此禹之功也。勤 勞為民，無苦乎禹者矣。

Xi shang gu Longmen wei kai, Lüliang wie fa, He chu Mengmen, da yi ni liu, wu you qiu ling wo yan, ping yuan gao fu, jin jie mie zhi, ming yue hong shui. Yu yushi shu he jue jiang, wei Pengli zhi zhang, gan dongtu, suo huo zhe qian ba bai guo, ci Yu zhi gong ye. Qin lao wei min, wei ku yu Yu zhe yi!

Long ago, in high antiquity, when Longmen (Dragon's Gate) had not yet been opened and Lüliang had not yet been made to flow freely, the He River flowed out of the Meng Gate, greatly flooded [the territory] and flowed in the opposite direction; there were no peaks and hills, wet lowlands, flat plains, high mounds [left] that were not be all and entirely inundated; this is called the Flood. In consequence of this, Yu sparsed [the nine branches of] of the He River and released the Jiang River, built the Pengli dike [and thus] dried the eastern lands; the very survival of the 1800 polities, this is Yu's work! But there were no bitter feelings in Yu from diligently tiring [himself] for the people!

One of the latest passages in this series, is found in the "Sima Xiangru liezhuan", is an interesing summary of all the aspects of Yu's works discussed above. It mentions in passing the drainage system established by $\mathrm{Yu}$, points out his exhausting personal engagement in physical work, without, however, reference to specific tools, and lays a special emphasis on the wearing out of his body: ${ }^{144}$

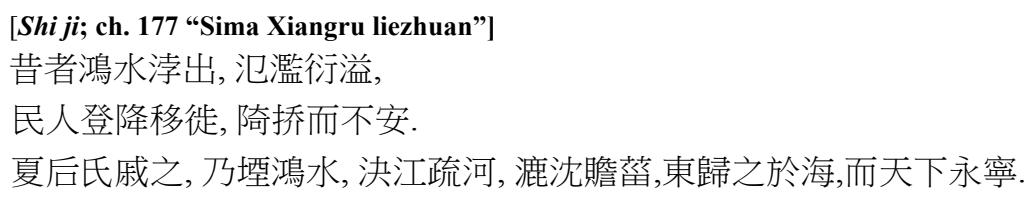

\footnotetext{
${ }^{143} \mathrm{Cf}$. footnote 102 above.

${ }^{144}$ Shi ji 史記, Ershisi shi 二十四史 ed., 1972, p. 3050. I took notice of this passage thanks to the opportunity to attend text-reading seminars on the Shi ji chapters (April-July 2011 and July 2012, München) in the framework of the translation project of this text directed by William H. Nienhauser and Hans van Ess. With slight differences I rely on translation of this passage by Hans van Ess in William H., Jr. Nienhauser, ed., 2016, p. 130; see also Anatoly R. Vyatkin, ed., 2010, p. 115.
} 


\begin{abstract}
當斯之勤, 豈唯民哉!
心煩於慮而身親其勞, 身胝無胧,膚不生毛.

故休烈顯乎無窮,聲稱浹乎于茲.

$X i$ zhe hongshui bo chu, fan lan yan yi,

Minren deng jiang yi tu, jijiao er bu an.

Xiahoushi qi zhi, nai yin hongshui, jue Jiang shu He, lu shen shan zai,

Dong gui zhi yu hai, er Tianxia yong ning.

Dang si zhi qin, qi wei min zai!

Xin fan yu lü er shen qin qi lao, gong zhi wu ba, fu bu sheng mao.

Gu xiu lie xian hu wu qiong, sheng cheng jia hu yu zi.

In former times when the great Flood poured out, bubbling forth and swelling vastly so that the people had to climb [mountains] and descend [the slopes] in order to change their settlements, they had to go on rough roads but did not find peace. Lord Xia-hou (夏侯氏 = the legendary Emperor $\mathrm{Yu}$ ) pitied them and then began to stem the Flood, releasing the Jiang River and sparsing [the nine branches of] the He River, ${ }^{145}$ dividing and deepening them in order to smoothen the effects of disasters. He led [the excess water] to the East into the sea and the Under-heaven became peaceful for ageless times. Such care was certainly not accomplished by just the [common] people! [His] heart burned with thoughts and [he] himself personally was doing the hard work. His body was covered by callouses (or: his body and backside) did not have flesh, and on his skin [there] grew no hair. Therefore his achievements shine gloriously for eternity and his name has been praised until today.
\end{abstract}

To sum up, references to Yu's personal handling of agricultural tools are found in a series of transmitted late Warring States - early Han texts in an almost standardised form, differing only in the specific tools mentioned, see Table 2. Exploring the specific tools behind each occurrence would be an interesing study in the history of Chinese technology. Here it is important to determine that all the tools share the same functional and conceptual applications. All were used in early China for agriculture and related soil-based construction, and all appear in the textual tradition as instruments that served $\mathrm{Yu}$ in his management of waterways. Finally, Yu's wielding of the tools has a clear affinity with the references to the Son of Heaven's ritual ploughing, as described in the first month Meng chun 孟春 in the "Yue ling" chapter, and throughout the Li ji, for

${ }^{145}$ It is noteworthy that in the "Sima Xiangru liezhuan" managing waterways by Yu proceeds from the Jiang to the He, that is from the south to the north. The sequence is inversed, if compared to the Lüshi chunqiu, which uses the same wording for Yu's managing rivers, in particular "sparsing [the nine branches of] of the He River" (shu He 疏河) and "releasing Jiang” (jue Jiang 決江), but follows the spatial sequence of Yu's labours in the "Yu gong", where description of the He [River] and its basin precedes the Jiang [River] and its basin, see Dorofeeva-Lichtmann, 1995, pp. 77-78 and 100 (fig. 10). The same spatial sequence is also respected in the Shanhai jing, in the "Itineraries of the Central Mountains" (Zhongshan jing 中山經) chapter of the "Shan jing", which roughly encompasses the central area of the Chinese territory: the "Central Mountains" begin from the He River cluster of itineraries and are followed by the Jiang River cluster (itineraries 15-21 and 22-26, respectively, see Map 6). The inversed sequence in the "Sima Xiangru liezhuan", therefore, conveys a view from the South. At the same time, jiang he 江河 appears to be a current binom throughout early Chinese texts, most probably due to phonetic harmony, and does not seem to convey a spatial statement, as it is the case, for instance, in the passage from the Zhuanzi cited in this article. I am grateful for this observation to one of the anonymous reviewers. 
instance, in the "Ji tong" 祭統 (Sacrifices United) chapter, where royal ploughing in the Southern Outskirts is mentioned. ${ }^{146}$ This affinity reveals the typological similarity of Yu's labours with the concept of the ritual initiation of seasonal agricultural works by the ruler. This simultaneously highlights the agricultural and ritual implications of Yu's ordering of terrestrial space. ${ }^{147}$

${ }^{146}$ Liji Zheng zhu (Sibu beiyao ed.), 5.3a; Legge, tr., 1985 (vol. 28), pp. 254-255 (§ 13). Couvreur, tr., 1913 (vol. 2), p. 322 (§ 5).

${ }^{147}$ For the ritual dimension of Yu's ordering of terrestrial space, see Dorofeeva-Lichtmann 2009 (repr. in 2019). 
Table 2. Yu's personal engagement in hard physical work

\begin{tabular}{|c|c|c|c|}
\hline $\begin{array}{l}\text { Written } \\
\text { source }\end{array}$ & Citation & Tools & Notes \\
\hline $\begin{array}{ll}\text { Rong } & \text { Cheng } \\
\text { shi } & \end{array}$ & $\begin{array}{l}\text { 禹親執枌(= 未 Li Ling, Qiu Dexiu/ 畚 Chen Jian et al.)䇃(=耤)... } \\
\text { Yu qin zhi fen (= lei/ben) si... } \\
\text { Yu personally held the plough handle (Li Ling)/bamboo or wicker } \\
\text { scoop (Chen Jian) and the ploughshare... }\end{array}$ & $\begin{array}{l}\text { 枌 fen }(=\text { 未 lei/畚 } \\
\text { ben }) \\
\text { plough handle/bamboo } \\
\text { or wicker scoop; } \\
\text { (=耟) } s i \\
\text { ploughshare }\end{array}$ & \multirow[t]{3}{*}{$\begin{array}{l}\text { agricultural } \\
\text { tools }\end{array}$} \\
\hline $\begin{array}{l}\text { "Tianxia" } \\
\text { Zhuangzi }\end{array}$ & $\begin{array}{l}\text { 禹親自操萦耟... Yu qinzi cao tuo si } \\
\text { Yu personally himself operated the sack/basket [for collecting } \\
\text { soil] and ploughshare... }\end{array}$ & $\begin{array}{l}\text { 㯻 tuo sack/basket } \\
\text { [for collecting soil] } \\
\text { 耜 si ploughshare }\end{array}$ & \\
\hline $\begin{array}{l}\text { "Wu du' } \\
\text { Han Feizi }\end{array}$ & $\begin{array}{l}\text { 禹之王天下也, } \\
\text { 身執未番, 以為民先. } \\
\text { Yu zhi wang Tianxie ye, } \\
\text { Shen zhi lei ben, yi wei min xian. } \\
\text { When Yu ruled the Under-heaven, } \\
\text { [he] himself held the plough handle and bamboo or wicker scoop, } \\
\text { by means of this became the leader of people. }\end{array}$ & $\begin{array}{l}\text { 未 } \text { 未ei } \\
\text { plough handle } \\
\text { 雷 ben } \\
\text { bamboo or wicker } \\
\text { scoop }\end{array}$ & \\
\hline $\begin{array}{l}\text { "Lüe yao" } \\
\text { Huainanzi }{ }^{149}\end{array}$ & $\begin{array}{l}\text { 禹身執蒙垂, 以為民先. } \\
\text { Yu shen zhi leil chui, yi wei min xian. } \\
\text { Yu himself held a dirt-basket and a bob, } \\
\text { by means of this became the leader of people. }\end{array}$ & $\begin{array}{l}\text { 萦 leil dirt-basket } \\
\text { 垂 chui bob }\end{array}$ & $\begin{array}{l}\text { Agricultural and } \\
\text { measuring tools }\end{array}$ \\
\hline $\begin{array}{l}\text { "Yu benji" } \\
\text { Shi ji }\end{array}$ & $\begin{array}{l}\text {...禹...乃勞身焦思... } \\
\ldots . . \text { 左準繩, 右規矩 ... } \\
\text {...Yu ...nai lao shen jiao si... } \\
\text {...... zuo runsheng, you guiju... } \\
\text { Yu... then was tiring his body by hard physical work and was } \\
\text { burning his mind... } \\
\text {...in the left hand was holding the level and the rope bob, in the } \\
\text { right hand the compass and the set square... }\end{array}$ & $\begin{array}{l}\text { 準繩 zhun sheng } \\
\text { level and rope bob } \\
\text { 規矩 gui ju compass } \\
\text { and set square }\end{array}$ & measuring tools \\
\hline $\begin{array}{l}\text { "Yue ling" } \\
L i j i\end{array}$ & $\begin{array}{l}\text { 天子親載未耤... } \\
\text { Tianzi qin zai lei si... } \\
\text { The Son of Heaven personally launched into action the plough } \\
\text { handle and the ploughshare... }\end{array}$ & $\begin{array}{l}\text { 未耜 lei } s i \\
\text { plough handle/ } \\
\text { ploughshare }\end{array}$ & \multirow[t]{2}{*}{$\begin{array}{ll}\text { Ritual } & \text { royal } \\
\text { ploughing } & \end{array}$} \\
\hline $\begin{array}{l}\text { "Ji tong" } \\
\text { Li ji }\end{array}$ & $\begin{array}{l}\text { 天子親耕於南郊... } \\
\text { Tianzi qin geng yu nanjiao... } \\
\text { The Son of Heaven personally ploughed in the Southern } \\
\text { outskirts.... }\end{array}$ & & \\
\hline "Zhongxia ji" & 禹立，勤勞天下，日夜不解... & & Yu’s \\
\hline
\end{tabular}

${ }^{148} \mathrm{Li}$ Ling supposes that 枌 could have been mistakenly written instead of 朸 $l i$, which he reads as 未 $l e i$ "plough handles, wooden part of the plough", see Ma Chengyuan, ed., p. 268. Indeed, in texts dating from the late Warring States through the early Han period 未 often forms a pair with the next character 耜 $s i$ "ploughshare, iron part of a plough", as in the "Yue ling". However, Chen Jian suggests that 枌 may stand for 畚 ben "bamboo or wicker scoop, dustpan", see Chen Jian 2004, p. 329. Liu Lexian, Su Jianzhou and Yan Shixuan (Yen Shih-Hsuan) support Chen Jian's suggestion with further arguments. Liu and Su refer to Zhuangzi, Han Feizi, Huainanzi and its citation in the Taiping Yulan 太平御覽, also occurrences of 畚 in the Guo yu 國語, Zhou Yu zhong 周語中 and its definition in Guang ya 廣雅, Shi qi 釋器, see Liu Lexian 31.01.2003 (§ 2); Su Jianzhou 2003, pp. 137-138 (§ 33). Yan Shixuan points out the possibility of using 枌 and 畚 as loan characters, see Yan Shixuan (Yen Shih-Hsuan) 20.02.2003, last paragraph, see also idem 2012. Yan Changgui, Chen Wei, and Zhu Yuanqing accept these arguments and use 畚 in their citations of the Rong Cheng shi, see Yan Changgui 2004a, p. 506; Chen Wei 2003, p. 42; Zhu Yuanqing 2004, p. 412.

${ }^{149}$ One can see that the "Wu du" of the Han Feizi and the "Lüe yao" of the Huainanzi contain almost identical phrases. 


\begin{tabular}{||l|l|l|l||}
\hline \hline Lüshi chunqiu & $\begin{array}{l}\text { Yu li, qin lao Tianxia, ri ye bu xie... } \\
\text { When Yu took the position of the ruler, he diligently tired } \\
\text { [himself] for the Under-heavens, day and night did not relax... }\end{array}$ & $\begin{array}{l}\text { physical } \\
\text { without } \\
\text { references } \\
\text { tools }\end{array}$ \\
\hline "Kai chun" & $\begin{array}{l}\text { 勤勞為民, 無苦乎禹者矣. } \\
\text { Qin lao wei min, wu ku hu Yu zhe yi! } \\
\text { But there were no bitter feelings in Yu from diligently tiring } \\
\text { [himself] for the people! }\end{array}$ & & \\
"Sima Xiangru & $\begin{array}{l}\text { 心煩於慮而身親其勞. } \\
\text { Xin fan yu lü er shen qin qi lao. } \\
\text { [His] heart burned with thoughts and [he] himself personally was } \\
\text { doing the hard work. }\end{array}$ & & \\
Shi ji
\end{tabular}

References to the worn-out state of Yu's body are much less common in early Chinese texts, and the special interest of the Rong Cheng shi manuscript is that it provides a new example of this attribute of the image of $\mathrm{Yu}$, even if this part of the manuscript is considerably damaged. All the occurrences report the two notable attributes of weariness - emaciated thighs and hairless shins - which due to their peculiarity became firmly associated with Yu, see Table 3.

Table 3. Visible manifestation of Yu's worn-out state and austerity

\begin{tabular}{|c|c|c|c|c|}
\hline $\begin{array}{l}\text { Written } \\
\text { source }\end{array}$ & Citation & $\begin{array}{l}\text { No flesh, } \\
\text { no hair and } \\
\text { other body } \\
\text { damages }\end{array}$ & $\begin{array}{l}\text { Mental } \\
\text { Burn-out }\end{array}$ & \begin{tabular}{ll}
\multicolumn{2}{l}{ Modest clothes } \\
and & other \\
modest living \\
habits
\end{tabular} \\
\hline Rong Cheng shi & 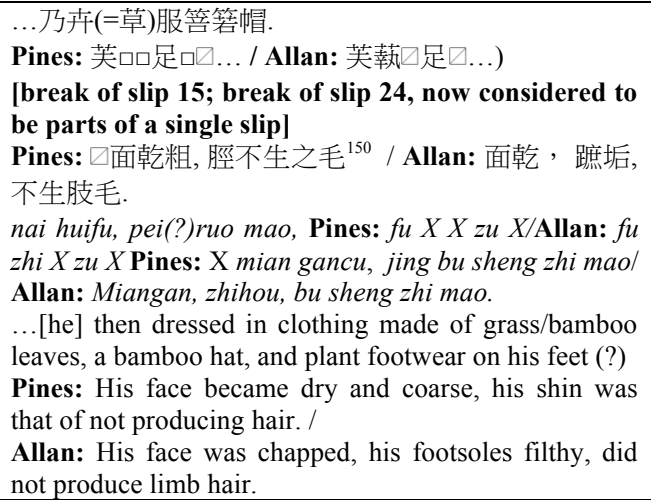 & + & & + \\
\hline $\begin{array}{l}\text { "Wu du" } \\
\text { Han Feizi }\end{array}$ & $\begin{array}{l}\text { 股無胧，脛不生毛... Gu wu ba, jing bu sheng mao... } \\
\text { Thighs did not have flesh, shin did not produce hair... }\end{array}$ & + & & \\
\hline $\begin{array}{l}\text { "Yu benji" } \\
\text { Shi ji }\end{array}$ & $\begin{array}{l}\text {...禹...乃勞身焦思...薄衣食...卑宮室... } \\
\text { Yu... nai lao shen jiao si... bo yi shi... bei gongshi... } \\
\text { Yu... then was tiring his body by hard physical work } \\
\text { and was burning his mind... Saved on clothes and } \\
\text { food...Kept low on palaces and chambers... }\end{array}$ & & + & + \\
\hline $\begin{array}{l}\text { "Sima Xiangru } \\
\text { liezhuan" } \\
\text { Shi ji }\end{array}$ & $\begin{array}{l}\text { 心煩於慮而身親其勞, 身胝無胧,膚不生毛. } \\
\text { Xin fan yu lü er shen qin qi lao, gong zhi wu ba, fu bu } \\
\text { sheng mao. } \\
\text { [His] heart burned with thoughts and [he] himself } \\
\text { personally was doing the hard work. His body was } \\
\text { covered by callouses (or: his body and backside) did } \\
\text { not have flesh, and on his skin there grew no hair. }\end{array}$ & + & + & \\
\hline
\end{tabular}

The issue of Yu's working with exceptional dedication is developed in the introduction to the complete citation of the "Yu gong" in the “Xia benji" 夏本紀 chapter

${ }^{150}$ Pines relies on Su Jianzhou 2003, p. 136 (§§ 28-29). 
of the Shi ji. Sima Qian assembles various details illustrating Yu's outstanding diligence from a broad range of sources, but adds new features and changes the emphasis. The physical eshaustion of Yu's body is supplemented with mental burn-out (lao shen jiao si 勞身焦思 - “tiring the body by hard physical work and burning the mind"), also found in the "Sima Xiangru liezhuan". Much attention is given to extreme austerity in his personal life (food, clothes, housing). Especially interesting here is the austerity in clothes, which is also described in detail in the Rong Cheng shi, unfortunately in a damaged part of the manuscript, but not in other transmitted texts. At the same time, the attributes of Yu's worn out body are not mentioned, and the agricultural implication of his labours is completely erased. Yet, tools still play a highly important role in Yu'a labours, but now they are tools of measurement not of agricultural work: zhun sheng 準 繩 (“level and rope bob”) and gui ju 規矩 (“compass and set square”): ${ }^{151}$

\begin{abstract}
[Shi ji, ch. 2 "Yu benji”]
禹...乃勞身焦思, 居外十三年, 過家門不敢入. 薄衣食, 致孝于鬼神. 卑宮室, 致費於溝淢...... 左準繩，右規矩...

Yu.. nai lao shen jiao si, ju wai shisan nian, guo jiamen bu ganru. Bo yi shi, zhi xiao yu guishen. Bei gongshi, zhi fei yu gouyu... ... zuo zhunsheng, you guiju...

Yu... then was tiring his body by hard physical work and was burning his mind, lived outside [his home] during 13 years, passing by the doors of his home did not dare to enter. Saved on clothes and food in order to perform filial piety to ghosts and spirits. Kept low on palaces and chambers in order to use all the means for drainage ditches and ravines... .... in the left hand was holding the level and the rope bob, in the right hand the compass and the set square...
\end{abstract}

The only case of a partial overlapping with the earliar references to Yu's tools is the occurrence in the "Yao lüe" of one agricultural and soil-construction and one measuring tool - leil chui 虆垂 (“dirt-basket and bob”). The consequences of this change of emphasis are quite considerable for the image presented of $\mathrm{Yu}-$ his body from that of a worn-out cripple becomes a perfect gauge for measurements: sheng wei lü, shen wei $d u$ 聲為律, 身為度 (“voice provided a [twelve-]pitch scale, body provided measurement gauges"), as it is stated in the passage preceding the description of his diligence in the "Xia benji". ${ }^{152}$ This image of Yu keeps to the letter of the canonical description of Yu's deeds in the Shang shu, where neither Yu's personal handling of agricultural tools nor his wearing out of his body is in evidence, and apparently was selected as most appropriate for imperial historiography. Elsewhere I advanced a hypothesis that the similarity between the beginning of the "Yu gong" and the short passage on drainage for tillage in the "Yi [and] Ji" ("Gao Yao mo 2" in Karlgren, § 9), which were discussed in

\footnotetext{
${ }^{151}$ Shi ji, Ershier shi, 2.52-78, for the "Nine Provinces", see pp. 52-66; for the introduction by Sima Qian, see p. 51 and its translations by Chavannes, tr., 1967 [repr. of 1895] (vol. 1), pp. 99-102; Vyatkin and Taskin, tr., 1972, pp. 151-152; Nienhauser, ed., 1994, p. 22.

${ }^{152} \mathrm{Cf}$. with the character sheng 聲 in slip 31 .
} 
Part I, allows one to suppose that drainage and establishing an orderly division of terrestrial space may be seen as alternative conceptions of terrestrial space. ${ }^{153}$ This study provides additional arguments in favour of this supposition. In the Shang shu the conception of drainage related to tillage plays a marginal role, and is described separately from its central conception of terrestrial space - the "Nine Provinces". Here, both mountains and rivers play an important role, but do not occupy an equal place managing landscape according to the "Yu gong" proceeds from mountains to rivers, and in addition rivers are described as ways of communication and not as elements of a drainage system. A more extreme case of the predominance of mountains in the conception of space is the Shanhai jing, where there is no place for Yu's personal involvement in any hard physical work. His is role is that of a foreman, the head of a team doing proper listing ( $j i$ 紀) of mountains and their properties, including rivers emanating from them, determining distances from mountain to mountain and thus paving land itineraries that map out terrestrial space. ${ }^{154}$ The Rong Cheng shi version of the "Nine Provinces", on the other hand, builds on waterways and is focused on drainage. It draws a direct connection between establishing the "Nine Provinces" and the procedure of draining excess waters through Yu's personal personal handling of agricultural tools and wearing out of his body. The Rong Cheng shi, therefore, successfully combines concepts related to Yu's labours, which then became separated in transmitted textual tradition.

To sum up, Yu's personal involvement in hard physical work and using agricultural tools in early Chinese texts correlates with a concept of his tailoring terrestrial space, which builds on waterways. The choice to opt for the predominance of waterways in the Rong Cheng shi was most likely influenced by its provenance from the Yangzi River basin, where complex managing of multiple waterways played an especially important role in communication and agriculture.

\section{Conclusions}

Investigation of terrestrial descriptions by landmarks combining philological analysis with exploration of relational mapping in traditional historical cartography shows that

\footnotetext{
${ }^{153}$ Dorofeeva-Lichtmann, 2010, pp. 38-43. Elsewhere I have pointed out another important difference between the Shang shu version of Yu's labours recognised in the dynastic histories, and alternative versions, the Shanhai jing in particular. This is Yu's link to spirits, see Dorofeeva-Lichtmann, 2009 [repr. In 2019]. Spirits are nowhere in evidence in relation to Yu in the Shang shu. Sima Qian makes an attempt to reconcile the Shang shu and the alternative versions in his introduction and also in the conclusion to the complete citation of the "Yu gong" in the "Yu Benji" chapter, but this link is then radically cut out in the Han shu 漢書, Ershisi shi 二十四史 ed., 1975, ch. 28 (“Dili zhi” 地理志 - “Treatise on Terrestrial Organisation"), pp. 1524-1538, for the "Nine Provinces", see pp. 1524-1532, for the introduction by Ban $\mathrm{Gu}$, see p. 1523 .

${ }^{154}$ Dorofeeva-Lichtmann 2007, p. 231.
} 
the description of the "Nine Provinces" in the Rong Cheng shi has close affinity to their description in the "Yu gong" and its four derivations - the "You shi lan", the "Shi di" and the "Zhi fang shi", both in wording and the areas covered. Landmarks found in all these five congener versions never transgress the southern border of the Yangzi River basin - Nanling and Wuyi mountain ranges. Yet, the extention of the spatial area covered by the "Nine Provinces" described in the Rong Cheng shi radically changes in the conclusion to their description, standing out with respect to the transmitted descriptions. It introduces into the scene the Han River as a demarcation line between the southern and northern halves of the mapped territories. The equality of South and North is expressed quantitatively - through the equal numbers of waterways comprised by each part. Positioning the Han River as the central axis is nowhere in evidence in any of the early Chinese descriptions of terrestrial space. In transmitted descriptions of the "Nine Provinces" the Han River delimits an area with two thirds to the North of it and one third to the South. If the Han River becomes the central axis dividing the mapped territory into equal southern and northern parts, it implies incorporating into the mapped area the territories extending far to the South all the way to the sea. Such positioning of the Han River appears in Chinese cartography showing the entire imperial realm, which includes the southern territories adjacent to the sea, and thus helps us to grasp the point of the spatial conception conveyed in the Rong Cheng shi. While formally faithful to the letter of the "Yu gong" group of the "Nine Provinces", the Rong Cheng shi introduces a cardinally new idea of terrestrial space, one in which Centre is shifted to the South. The southern territories are only implied and are not filled out by any landmarks, and this disposition may have seemed too speculative, if such a graphic image - the 'Nine Provinces' filled out by landmarks and an empty, but still included into the picture, southern territories - had not been found in one of the earliest maps of the "Yu gong" topography (Map 4). The enlargement of the mapped area through implicitely including into it the southern territories is also expressed quantitatively: the total number of waterways - five hundred in the South and five hundred in the North - make up one thousand, considerably larger that in similar totals of waterways in transmitted texts three hundred in the Zhuangzi or six hundred in the Lüshi chunqiu.

Another characteristic of the representation of terrestrial space in the Rong Cheng $s h i$ is the general predominance of waterways over the noticeably sparse references to mountains, and especially managing landscape features, beginning from waters, as stated in slip 31. The view of a landscape focused on waterways is the inverse of that in the "Yu gong", and also in the Er ya and the Shanhai jing, where mountains predominate over rivers and regulation or description of terrestrial space begins from mountains. If not a predominance, an outstandingly rich vocabulary for waterways is found in the Chu Manuscript no.1. This focus on waterways may not be an exclusively Chu feature of conceptualising space, but prioritising waters in texts of Chu provenance may well have been influenced by the natural features of Chu territory. 
A certain correlation can be detected in transmitted early texts between the idea of the draining of the floodwaters by $\mathrm{Yu}$ and his personal usage of tools, many of them for agricultural purposes. The description of the Rong cheng shi provides a clear illustration of this correlation. It primarily builds on the idea of drainage and includes reference to Yu's personal usage of tools, intertwoven into the description.

The canonical version of putting in order terrestrial space disordered by the Flood in the Shang shu distinguishes two actors and two phases. Regulation of terrestrial space is initiated by Shun, who performed the ritual tour of inspection according to a twelve-fold tempo-spatial model, and is completed by $\mathrm{Yu}$, who established the ideal model of territorial division into the "Nine Provinces". Slip 31 describes a ritual performed according to a twelve-fold spatial model, and I suggest that the Rong Cheng shi may also credit regulation of terrestrial space to Shun and to $\mathrm{Yu}$, allowing one to place this controversial slip prior to the set of slips describing Yu's activities.

In sum, the conception of terrestrial space that can be derived from the Rong Cheng shi shares many points in common with the canonical version of the Shang shu, but also includes spatial concepts from other transmitted texts that did not become included in the Confucian canon. Still, while sharing these common spatial concepts, due to shifting the Centre and the implied territorial expansion to the South, the Rong Cheng shi provides a view from a Chu perspective.

\section{Postface: The Afterlife of a Spatial Concept}

The predominance of waters in the Rong Cheng shi description of the "Nine Provinces" calls our attention to a concept of "provinces" as a set of pieces of "habitable" land amidst waters. In transmitted early Chinese texts this concept not only plays a marginal role, but also appears relatively late, by the end of the Western Han dynasty. It is briefly formulated in the definition of zhou 州 in the Shuowen jiezi ("Explaining Graphs and Dissecting Characters", compiled by 100 AD by Xu Shen 許慎, ca. 58 - ca. 147 AD) dictionary. ${ }^{155}$ The definition of zhou in the Shuowen jiezi elaborates on the definition of zhoul 洲 ("river island") in the $\operatorname{Er} y a .{ }^{156}$ The concept is further developed in the opening section of the Dili zhi 地理志 chapter of the Han shu 漢書 ("History of the [Former] Han dynasty") by Ban Gu 班固 (AD 32-92), ${ }^{157}$ thus giving the impression of being a Han innovation, one that although it relied on the description of the Flood in the Shang shu, as a concept did not exist earlier and did not receive broader diffusion

\footnotetext{
${ }^{155}$ Shuowen jiezi zhu 說文解子注 (1986), p. 569.

${ }^{156}$ Er ya Guo zhu (Sibu beiyao ed.), 7/10a.

${ }^{157}$ Han shu, Ershisi shi 二十四史 ed., 1975, ch. 28 (“Dili zhi”), p. 1523.
} 
later. ${ }^{158}$ Indeed, in the cluster of written sources on the "Nine Provinces" dating from the late Warring States to the early Western Han periods this concept is nowhere in evidence. ${ }^{159}$ The description of the "Nine Provinces" in the Rong Cheng shi as pieces of "habitable" land emerging from drained waters pushes the origins of this spatial concept back to the late $4^{\text {th }}$ century BC. ${ }^{160}$

A visual image of the core Chinese territories represented as pieces of land encompassed by rivers appears in maps of the Ming Empire included in popular encyclopaedia. One such map entitled "The comprehensive general map of the fenye correlation between the 28 logdes with the 'provinces'-sheng of the Imperial Ming" (Ershiba xiu fenye huang Ming gesheng di yu zong $t u$ 二十八宿分野皇明各省地輿總圖) is found in the encyclopaedia Bianyong Xuehai qunyu 便用學海群玉 (“Convenient to Use: Seas of Knowledge, Mines of Jade," printed in 1607). ${ }^{161}$ "Provinces"-zhou are listed here among other toponyms, thus showing the link with a "provinces" concept, see Map 8. The set of "provinces" names borrowed from the "Yu gong" has in this map an interesting mistake: $\mathrm{Xu}$ 徐 province appears twice, the second time erroneously instead of the central province $\mathrm{Yu}$ 豫. It is noteworthy that in the Rong Cheng shi the central "province" is designated by a homophone of $\mathrm{Xu}$ - 敘, which is synonym of $\mathrm{Yu} .{ }^{162}$ This map and a version of such a map incorporated into the Selden Map (ca. 1619) are briefly discussed by Robert Batchelor. ${ }^{163}$ Such specimens of popular cartography, which I refer to as "cosmographic maps", continued to successfully co-exist with Western-style maps resulting from the diffusion of Western cartography up to the end of the imperial China. ${ }^{164}$ The cosmographic representations of the Chinese Empire under the Ming and

\footnotetext{
${ }^{158}$ Modes of tailouring terrestrial space into "provinces", indeed, continued to occcupy the Han mind and sometimes brought forward original concepts, see, for instance, the one by Zheng Xuan 鄭玄 (AD 1272000), as reconstructed by Hans van Ess 1993, pp. 141-144.

${ }^{159}$ Dorofeeva-Lichtmann 2019 [rev. 2009]. A shadow of this concept can be seen in the Er ya version of the "Nine Provinces", which "provinces" are delimited exclusively by rivers, but it is not explicitely formulated.

${ }^{160}$ Dorofeeva-Lichtmann 2010, pp. 39-40.

${ }^{161}$ For the correlative cosmology, see Henderson 1984, 1994; Pankenier 2013.

${ }^{162}$ Dorofeeva-Lichtmann 2010, pp. 29-30.

${ }^{163}$ Batchelor 2013, pp. 43-45; 2014, pp. 290, footnotes 130 and 131.

${ }^{164}$ Two versions of such cosmographic maps of the Qing Empire in the form of a wall-map were recently acquired by the Max-Planck-Institute für Wissenschaftsgeschichte, see https://vzlbs3.gbv.de/DB=12.1/XMLPRS=N/PPN?PPN=1025141180, https://vzlbs3.gbv.de/DB=12.1/XMLPRS=N/PPN?PPN=1030255865. Both were drawn between 18991902. The date of the two maps was determined by Yang Yulei, Zhejiang University and Visiting Fellow of the Max-Planck Institute for the History of Science in 2018 and 2019 by a meticulous analysis of all the administrative units in the maps. Neither these two maps nor their close congeners have been described in scholarly literature yet.
} 
the Qing dynasties has up to now received modest scholarly attention in studies of the history of cartography in late imperial China, and their place seems to have been underestimated. These maps can, indeed, be only comprehended if seen with respect to their foundations in the early Chinese cosmography. The description of the "Nine Provinces" in the Rong Cheng shi manuscript together with the definition of "province" in the Shuowen jiezi dictionary may be considered among the early source texts for these maps. The route from a spatial concept as described in early texts to late imperial cosmographic maps is complex. Along the way some features of the initial concept may be transformed or some added to. ${ }^{165}$ This requires a special study, but the undeniable link between them illustrates the concept's longevity.

\footnotetext{
${ }^{165}$ For an example of two interrelated spatial concepts with a long history from the early Chinese textual tradition through to late imperial cartography as well as Western maps of China - the Yellow River source and Kunlun Mountain, see Dorofeeva-Lichtmann 2012.
} 


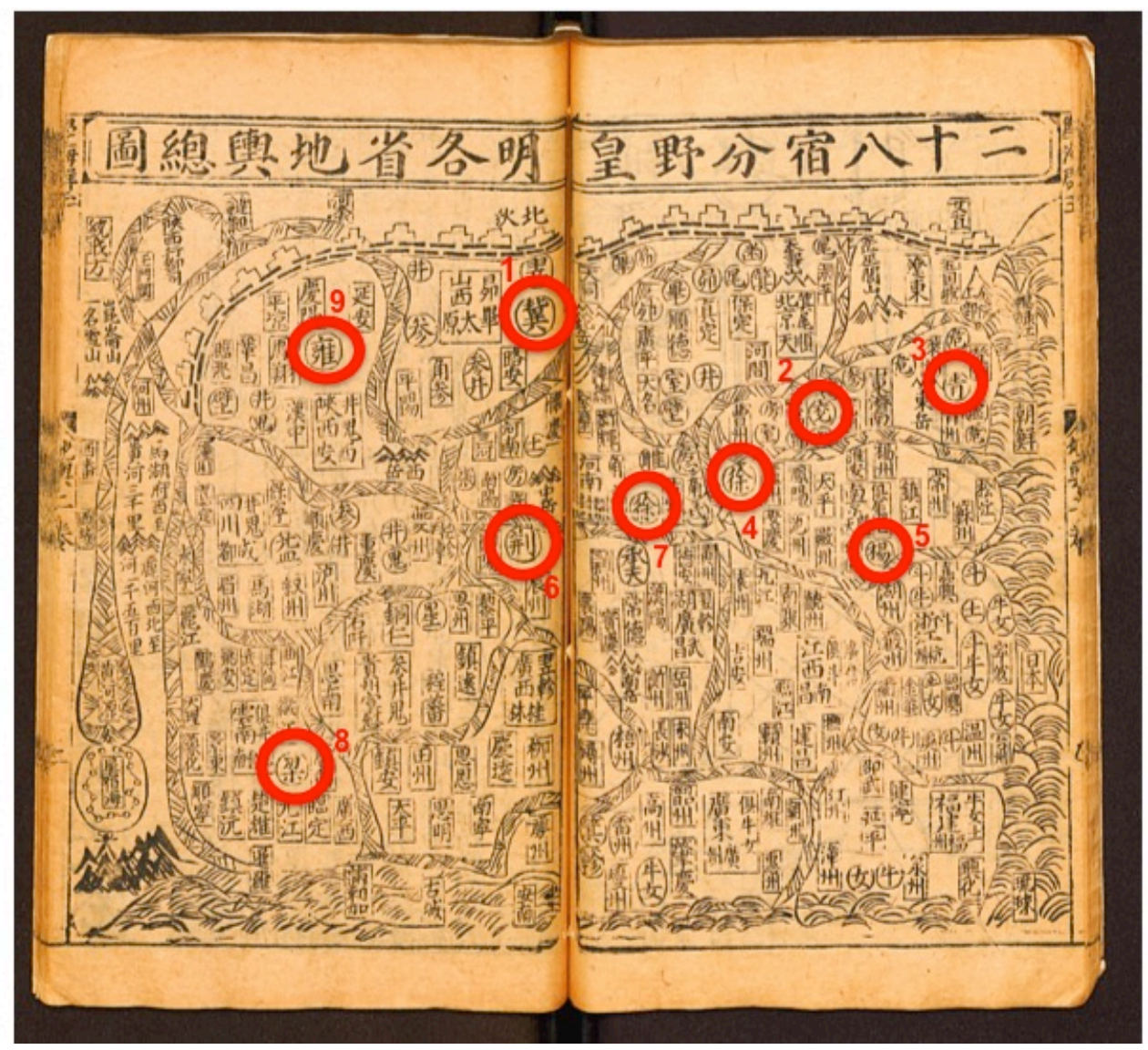

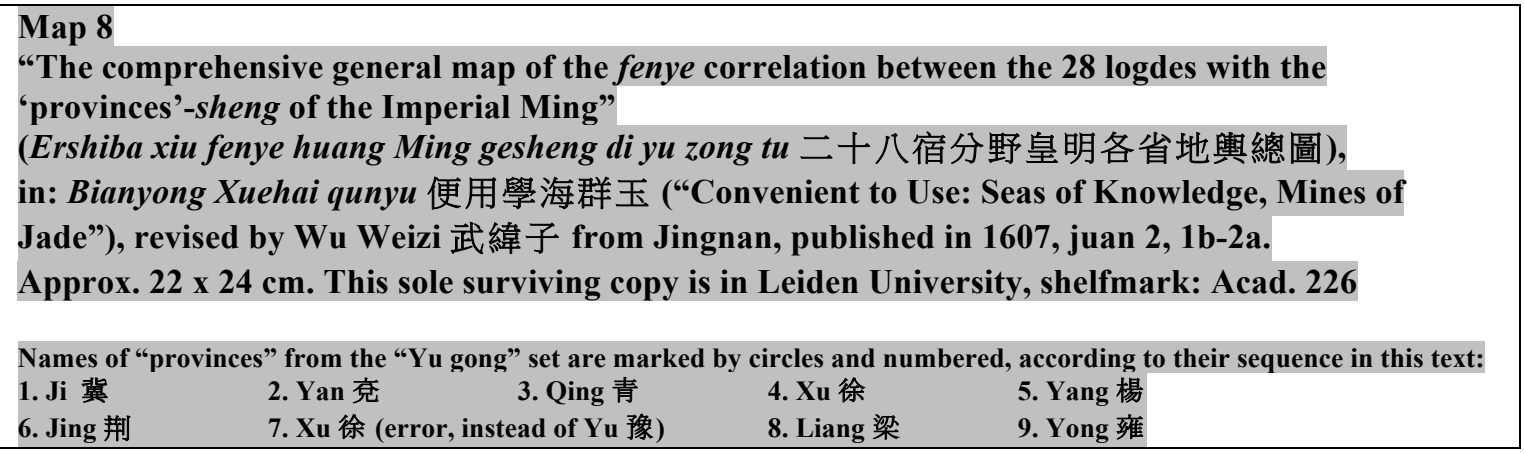

The concept of "provinces" as pieces of "habitable" land amidst waters both in the early written tradition and in the later cartographical tradition has been largely overshadowed by the "Yu gong" version of the "Nine Provinces", which became officially recognised since Han dynasty historiography. In the written tradition this concept is barely mentioned in transmitted texts and its detailed description became known only due to the discovery of the Rong Cheng shi manuscript. The earliest surviving representations of the Chinese Empire known from the Southern Song dynasty are largely based on the "Yu gong" version of the "Nine Provinces". Beginning from the Ming dynasty, the "Yu gong"-related maps fade out of imperial cartography and become 
historical maps. ${ }^{166}$ Examples of popular cosmography emerge together with general maps less oriented to the classical texts and primarily aimed at mapping the contemporary territorial divisions of the Empire as part of the imperial enterprise. It is of special interest that these specimens are based on the marginal concept of "provinces" as pieces of "habitable" land, and, therefore, show that this concept continued to co-exist with the officially recognised "Yu gong" version in the same way as the Rong Cheng shi co-existed with it in the early written tradition.

\footnotetext{
${ }^{166}$ Considerable changes in Chinese cartography are attested since the Yuan dynasty, and can be judged from the Ming dynasty cartography. Such changes include a cardinally new concept and respective cartographical image of the source of the Yellow River and the introduction of a new dominant cartographical symbol - the desert zone Shamo 沙漠, which become distinctive features of these maps and their dating criteria, see Dorofeeva-Lichtmann 2012.
} 


\section{APPENDIX}

\begin{tabular}{|c|c|}
\hline \multicolumn{2}{|r|}{$\begin{array}{l}\text { Yu's establishment of the "Nine Provinces" in the Rong Cheng shi: } \\
\text { from uninhabitable terrestrial space to perfectly structured dwelling places } \\
\text { (slips } 31 \text { and the sequence } 23-15=24-25-26-27-28-29 \text { ) }\end{array}$} \\
\hline $\begin{array}{l}\text { slip 31, beginning } \\
\text { from character } \\
N^{\circ} 3\end{array}$ & $\begin{array}{l}\text { 方爲三俈, } \\
\text { 救聲之紀: } \\
\text { 東方爲三俈, } \\
\text { 西方爲 三俈, } \\
\text { 南方爲三俈, } \\
\text { 北方爲三俈, } \\
\text { 以徫(越)於溪浴, 濟於廣川, } \\
\text { 高山债, 菜林...[end of slip 31] } \\
\text { fang wei san gao,qiu sheng zhi ji: } \\
\text { dong fang wei san gao, xi fang wei san gao, } \\
\text { nan fang wei san gao, bei fang wei san gao, } \\
\text { yi wei (yue) yu xi yu, ji yu guang chuan, } \\
\text { gao shan sheng, zhen lin... } \\
\text { At/to every cardinal direction [he] performed three gao ceremonies, } \\
\text { seeking the proper order of the sounds: } \\
\text { in/to the East performed three gao ceremonies, } \\
\text { in/to the West performed three gao ceremonies, } \\
\text { in/to the South performed three gao ceremonies, } \\
\text { in/to the North performed three gao ceremonies. } \\
\text { This enabled [him] to traverse brooks and river-valleys, cross broad rivers; } \\
\text { high mountains became ascendable, dense forests.... }\end{array}$ \\
\hline $\begin{array}{l}\text { Unhabitable } \\
\text { terrestrial } \\
\text { space and } \\
\text { Yu's } \\
\text { appointment } \\
\text { as the Master } \\
\text { of Public } \\
\text { Works } \\
\text { [slip 23] }\end{array}$ & 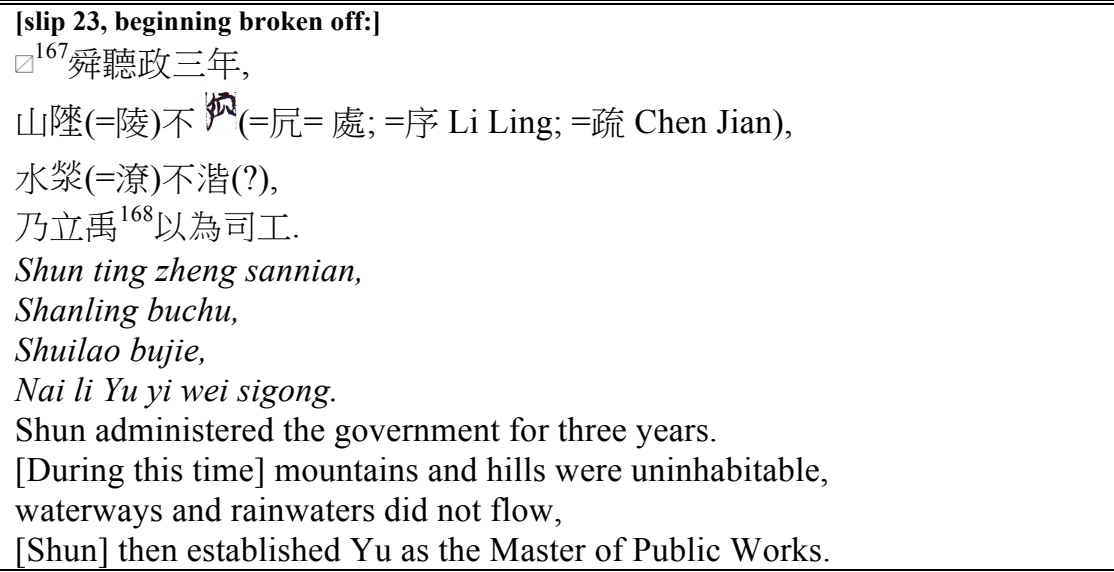 \\
\hline
\end{tabular}

${ }^{167} \square$ - broken end of a slip.

${ }^{168}$ In the Rong Cheng shi Yu's name is written with the radical "soil" below, as is often the case in Chu

manuscripts: 惠 


\begin{tabular}{|c|c|}
\hline $\begin{array}{l}\text { Yu's austerity } \\
\text { and worn-out } \\
\text { body } \\
\text { [slips 23-15- } \\
24 \text { ] }\end{array}$ & 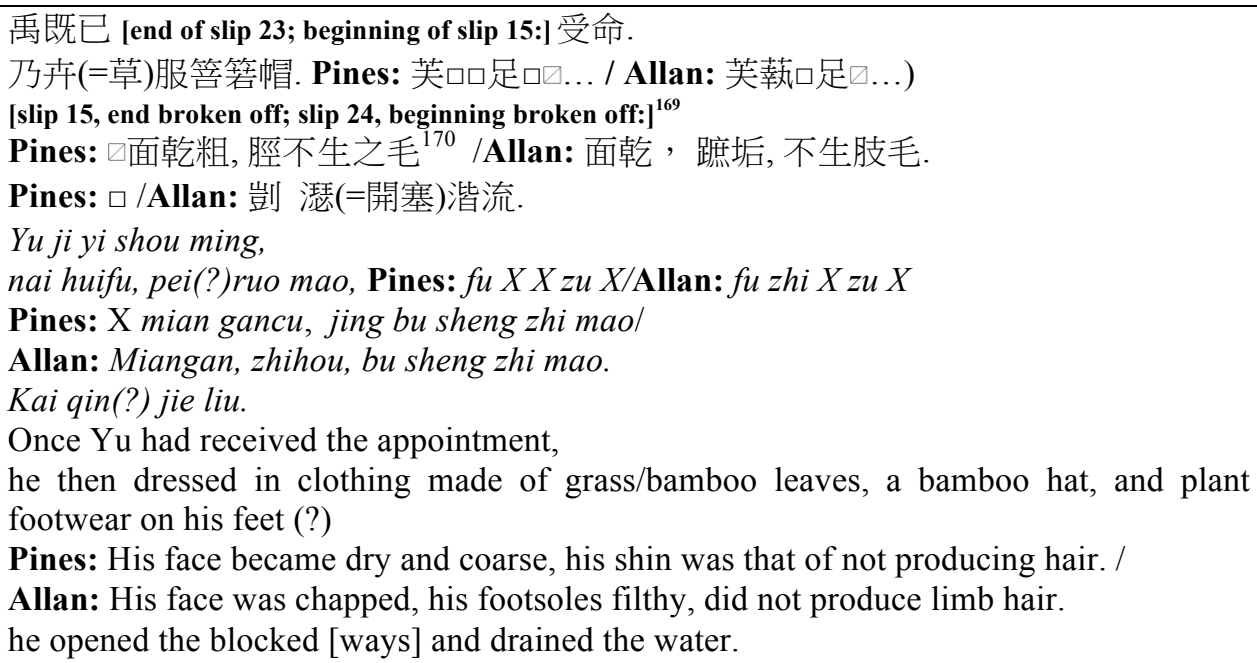 \\
\hline & Establishment of the "provinces" as pieces of habitable land [slips 24-27] \\
\hline $\begin{array}{l}\text { 1. Jia and Tu } \\
\text { pair of } \\
\text { "provinces" } \\
\text { (North-East) }\end{array}$ & 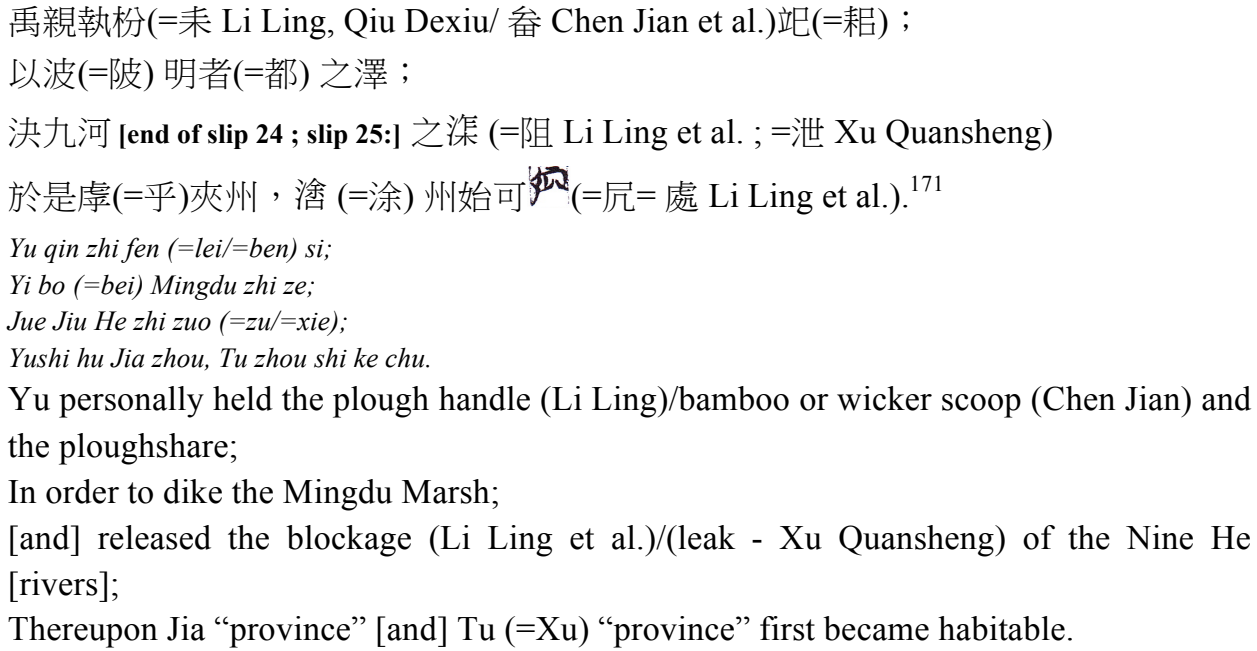 \\
\hline $\begin{array}{l}\text { 2. Jing1 and } \\
\mathrm{Fu} \\
\text { "provinces" } \\
\text { (East) }\end{array}$ & 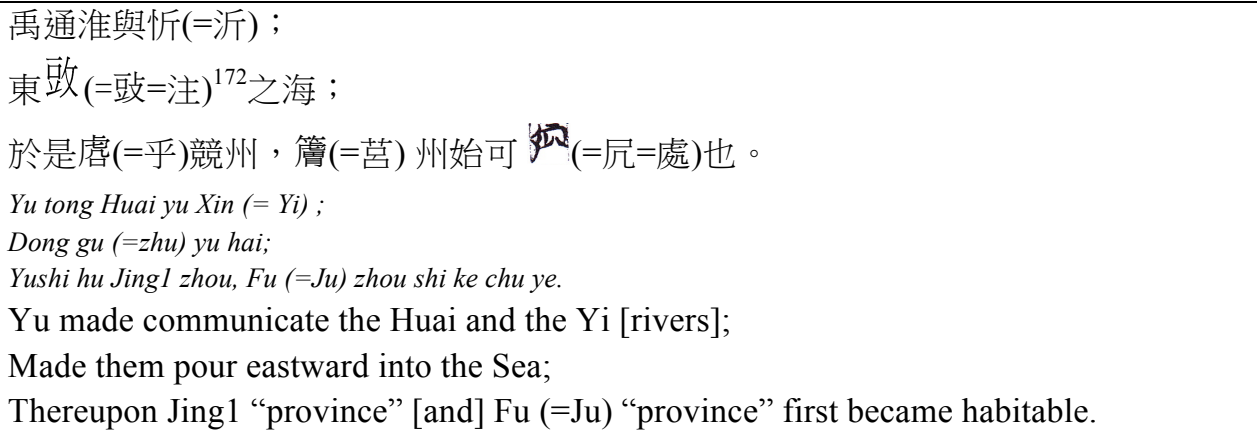 \\
\hline
\end{tabular}

${ }^{169}$ Slips 15 and 24 are now considered to ba parts of a single slip.

${ }^{170}$ Pines refers to Su Jianzhou (2003), p. 136, §§ 28-29.

${ }^{171} \mathrm{Xu}$ Quansheng 14.01.2003 and Qiu Dexiu 2003, pp. 403-434, identify the character (杘) here and in the following parallel passages with 居, This identification is, however, erroneous, as a clearly written 蛙 occurs in slip 28 .

${ }^{172}$ For the reasons of identification of 敳 (variant of 鼓) with 注, here and in the following parallel passages, see Qiu Dexiu 2003, p. 412. 


\begin{tabular}{|c|c|}
\hline $\begin{array}{l}\text { 3. Luo/Ou } \\
\text { "province" } \\
\text { (North) }\end{array}$ & 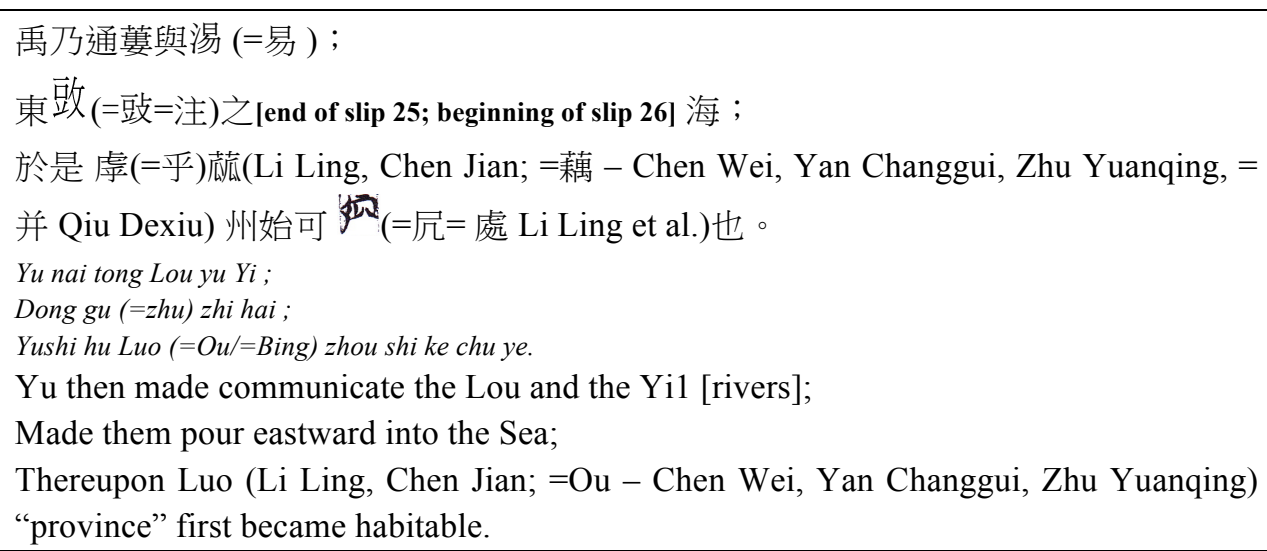 \\
\hline $\begin{array}{l}4 . \quad \text { Jing and } \\
\text { Yang } \\
\text { 'provinces' } \\
\text { (South) }\end{array}$ & $\begin{array}{l}\text { 禹乃通三江、五 沽 (=湖)； } \\
\text { 東敳 (=鼓=注)之海； } \\
\text { 於是虎(=乎) 型(=荊) 州，惖 (=揚/楊) 州始可 } \\
\text { Yu nai tong San Jian, Wu Hu; } \\
\text { Dong gu (=zhu) zhi hai; } \\
\text { Yushi hu Jing zhou, Yang zhou shi ke chu ye. } \\
\text { Yu then made communicate the Three Jiang [rivers] and the Five Lakes; } \\
\text { Made them pour eastward into the Sea; } \\
\text { Thereupon Jing “province” [and] Yang “province” first became habitable. }\end{array}$ \\
\hline $\begin{array}{l}5 . \quad \mathrm{Xu1} \\
\text { "province" } \\
\text { (Centre) }\end{array}$ & 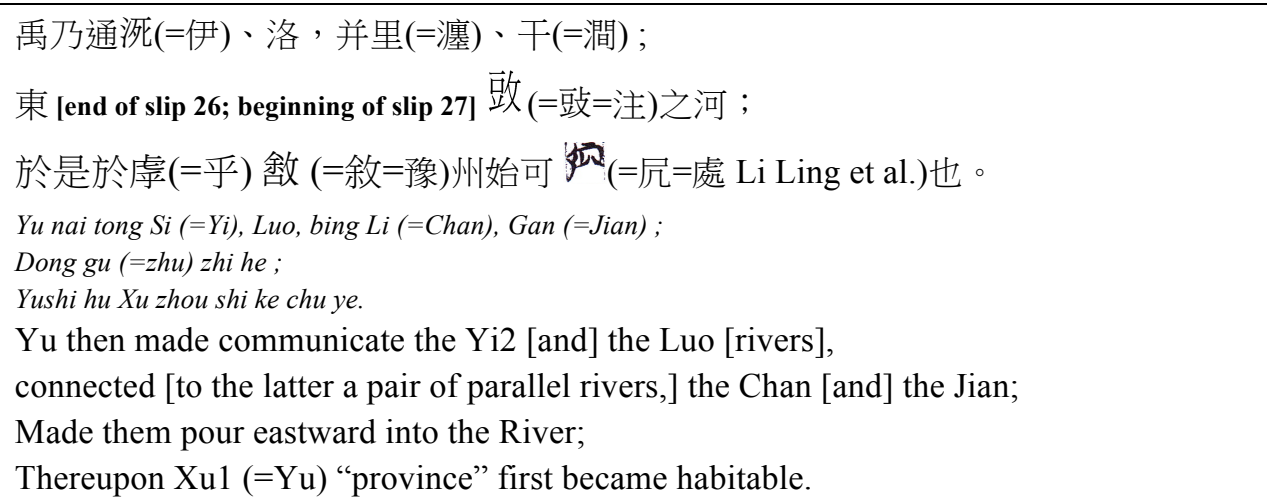 \\
\hline $\begin{array}{l}6 . \quad \text { Ju1 } \\
\text { "province" } \\
\text { (West) }\end{array}$ & 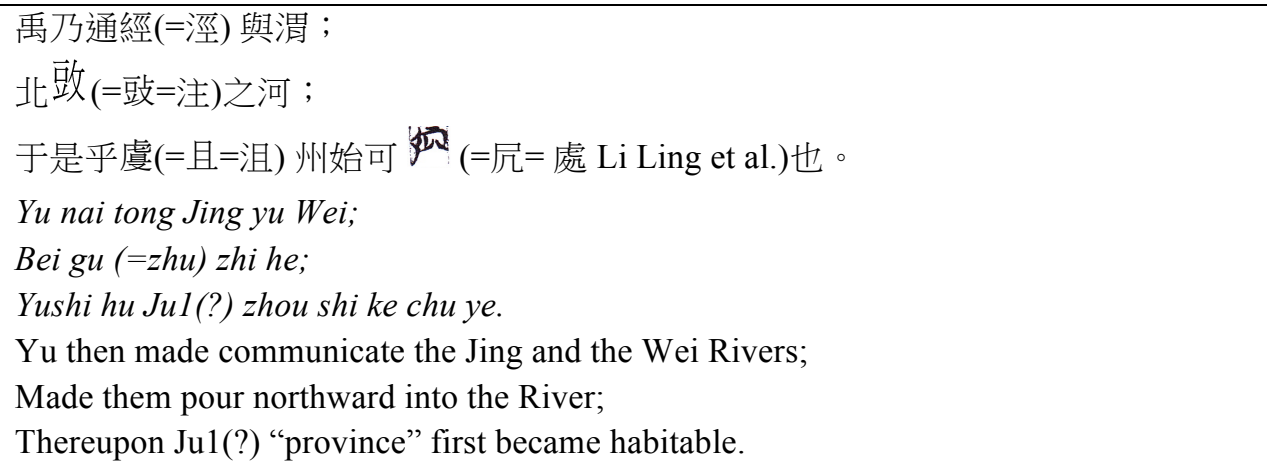 \\
\hline $\begin{array}{l}\text { South-North } \\
\text { demarcation } \\
\text { along } \\
\text { the Han River }\end{array}$ & $\begin{array}{l}\text { 禹乃從䕿(=灘=漢) 以南為名浴(=谷)五百, } \\
\quad \text { 從 [end of slip 27; beginning of slip 28] 䕿(=灘=漢) 以北為名浴(=谷)五百。 } \\
\text { Yu nai cong Han yu nan wei ming yu wu bai, } \\
\quad \text { cong Han yi bei wei ming yu wu bai. } \\
\text { Yu then } \\
\text { to the South from the Han [River] created } 500 \text { named river-valleys, }\end{array}$ \\
\hline
\end{tabular}




\begin{tabular}{|c|l||}
\hline \hline & to the North from the Han [River] created 500 named river-valleys. \\
\hline Dwelling & 天下之民㣖(=居) 奠。173 \\
places settled & Tianxia zhi min ju dian. \\
& The dwelling places of people through the Under-Heavens [thus] became settled. \\
\hline \hline
\end{tabular}

\footnotetext{
${ }^{173}$ The follow-up to Yu's spatial stabilisation, as described in the Rong Cheng shi (slips 28-29), is similar to the impact of draining the waters of the Flood, as described in the "Yi [and] Ji" (Karlgren: "Gao Yao mo 2", § 9) referred to above: development of agriculture under the guidance of Houji 后稷, which ensured an abundance of food for the people, see Dorofeeva-Lichtmann 2010, pp. 38-39. At the end of this paragraph in the "Yi [and] Ji" there is a reference to "changing dwelling places" (化居 huaju), which could provide another interesting parallel with the Rong Cheng shi, but its context is difficult to grasp.
} 


\section{REFERENCES}

\section{PRIMARY SOURCES}

Biot, Edouard (trans.) (1969 [repr. of 1851]). Le Tcheou-li ou Rites des Tcheou, vol. II. Taibei: Ch'eng Wen Publiching Co.

CAO Wanru 曹婉如, ZHENG Xihuang 鄭錫煌, HuANG Shengzhang 黃盛璋 et al., (eds.) (1999 [repr. of 1990]). Zhongguo gudai dituji: Zhanguo - Yuan 中國古代地 圖集：戰國- 元 / An Atlas of Ancient Maps in China - From the Warring States Period to the Yuan Dynasty (476 B.C.-A.D.1368). Beijing: Wenwu chubanshe.

Chavannes, Edouard (trans.) (1967 [repr. of Paris, Ernest Leroux, 1895]). Les Mémoires Historiques de Se-ma Ts'ien, Vol. 1. Paris: Adrien Maisonneuve.

Chemla, Karine and Guo Shuchun (trans.) (2004). Le classique mathématique de la Chine ancienne et ses commentaires. Paris: Dunod.

Chen Guying 陳鼓應 (1983). Zhuangzi jinzhu jinyi 莊子今注今譯 (Zhuang zi with a new commentary and new translation)

Beijing: Zhonghua shuju.

Couvreur, Séraphin (trans., comprises original text). (1897). Chou King. Ho Kien Fou: Imprimérie de la Mission Catholique [repr. of 1971].

Couvreur, Séraphin (trans.) (1913). Li Ki, ou Mémoires sur les bienséances; texte Chinois avec une double traduction en Francais et en Latin, 2 vols. Hokkien: Mission Catholique. [reprint: Paris, Cathasia, 1950 (Paris-Leiden: Cathasia-Brill)].

Erya Guozhu 爾雅郭注 (Erya dictionary with commentary by Guo Pu), Sibu beiyao 四部 備要 ed. (1927-1935). Shanghai: Zhonghua shuju.

Giles, Herbert. A. (trans.) (1926 [repr. of 1889]). Chuang Tzû: Moralist, Moralist, and Social Reformer. Shanghai. Kelly \& Walsh, Ltd.

Graham, Angus C. (1991 [repr. 1981]). Chuang-tsû: The Inner Chapters. London: Mandala.

Hanfeizi jishi 韓非子集釋 (Collected elucidations on Master Han Fei) [Chen Qiyou 陳奇 猷 ed.] (1974). Shanghai: Shanghai renmin chubanshe.

Han shu 漢書(1975). Ershisi shi二十四史 series. Beijing: Zhonghua shuju. 
Huainan honglie jijie 淮南鴻烈集解 (Extensive collected unravellations of [Masters] from Huai Nan) [Xinbian zhuzi jicheng 新編諸子集成 ed.] (1989). Beijing: Zhonghua shuju.

Karlgren, Bernhard (1948). "Glosses on the Book of Documents." Bulletin of the Museum of Far Eastern Antiquities 20: 39-315.

Karlgren, Bernhard (1949). "Glosses on the Book of Documents." Bulletin of the Museum of Far Eastern Antiquities 21: 63-206.

Karlgren, Bernhard (trans., comprises original text) (1950). "The Book of Documents." Bulletin of the Museum of Far Eastern Antiquities 22: 1-81.

Knoblock, John, and Jeffrey Riegel (trans., comprises original text) (2000). The Annals of Lü Buwei: a Complete Translation and Study. Stanford: Stanford University Press.

Kamenarovic, Ivan P. (trans.) (1998). Printemps et automnes de Lü Buwei. Paris: Les Editions du Cerf.

Le Blanc, Charles, and Rémi Mathieu (trans.) (2003). Philosophes taoïstes, II, Huainan zi, Paris, Gallimard (collection de "la Pléiade").

Legge, James (trans., comprises original text) (1865). The Chinese Classics, Vol. 3, Part 1 (Shoo King). Hongkong - London: London Missionary Society's Printing Office.

Legge, James (trans.) (1885). The Sacred Books of China: The Texts of Confucianism, Part III, The Lî Kî, I-X., in: The Sacred Books of the East, vol. 27, ed. F. Max Müller. Oxford: At the Clarendon Press.

Legge, James (trans.) (1885). The Sacred Books of China: The Texts of Confucianism, Part III, The Lî Kî, XI-XLVI, in: The Sacred Books of the East, vol. 28, ed. F. Max Müller. Oxford: At the Clarendon Press.

Legge, James (trans., introduction by D.T.Suzuki) (1959 [repr. of 1885]). The Texts of

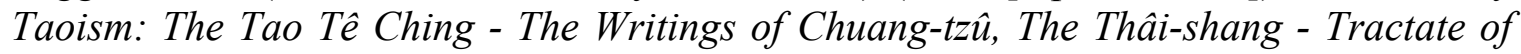
Actions and Their Retributions. New York: The Julian Press, Inc.

Li Xueqin 李學勤, ed. (2011). Qinghua Daxue cang Zhanguo zhujian 清華大學藏戰國 竹簡, vol. 1. Shanghai: Zhonghua zhuju.

Liji Zheng zhu 禮記鄭注, Sibu beiyao 四部備要 ed. (1927-1935). Shanghai: Zhonghua shuju.

Liao, Wen-kwei (trans.) (1959). The Complete Works of Han Fei Tzu, vol. 2. London: Arthur Probsthain. 
Liou Kia-hway (1969). Tchouang-tseu, oeuvre complete. Paris: Gallimard/Unesco, 1969.

Lüshi chunqiu 呂氏春秋, Sibu beiyao 四部備要 ed. (1927-1935). Shanghai: Zhonghua shuju.

Ma Chengyuan 馬承源 (ed.-in-chief) (2002). Shanghai bowuguan cang Zhanguo Chu zhushu 上海博物館藏戰國楚竹書 (Chu bamboo strips of the Warring States period from the Shanghai Museum), vol. 2. Shanghai: Shanghai guji chubanche.

Mair, Victor H. (trans.) (1994). Wandering on the Way: Early Taoist Tales and Parables of Chuang Tzu. New York - Toronto - London - Sydney - Auckland: Bantam Books.

Major, John S. (trans.) (1993). Heaven and Earth in Early Chinese Thought (Chapters Three, Four and Five of the Huai nan zi). Albany: State University of New York Press.

Major, John S., Sarah A. Queen, Andrew Seth Meyer, Harold D. Roth (trans.) (2010). The Huainanzi: A Guide to the Theory and Practice of Government in Early Han China, by Liu An, King of Huainan. New York: Columbia University Press.

Major, John S., Sarah A. Queen, Andrew Seth Meyer, Harold D. Roth (trans.) (2012). The Essential Huainanzi: Liu An, King of Huainan. New York: Columbia University Press.

Malyavin, Vladimir V. (trans., introduction, commentary) (2002). Chzhuan-zy (Zhuang zi). In : Kitaiskaya Klassika : novye perevody, novy vzglyad. Daosskie kanony (Chinese Classics : new translations, new perspective. Daoist canons). Moscow : Astrel'.

Mathieu, Rémi (trans.) (1983). Etude sur la mythologie et l'ethnologie de la Chine Ancienne. Tome I: Traduction annotée du Shanhai jing. Tome II: Index du Shanhai jing. (Memoires de l'Institut des Hautes Etudes Chinoises, Vol. 22). Paris: Collège de France Institut des Hautes Etudes Chinoises.

Nienhauser, William H. (ed.) (1994). The Grand Scribe's Records, Vol. I. The Basic Annals of Pre-Han China by Ssu-ma Ch'ien. Bloomington \& Indianapolis: Indiana University Press.

Nienhauser, William H. (ed.) (1994). The Grand Scribe's Records, Vol. I. The Basic Annals of Pre-Han China by Ssu-ma Ch'ien. Bloomington \& Indianapolis: Indiana University Press.

Nienhauser, William H., Jr. ed. (2016). THE GRAND SCRIBE'S RECORDS, BY SSU-MA CH'IEN. Volume X: The Memoirs of Han China, Part III, translators of the volume: Chiu Ming Chan, Hans van Ess, William H. Nienhauser, Jr., Thomas D. Noel, Marc Nürnberger, Jacob Pöllath, Andreas Siegl, and Lianlian Wu. Bloomington \& Indianapolis: Indiana University Press, 2016. 
Pozdneeva, Larisa D. (1994 [repr. of 1967]). Mudretsy Kitaya (Sages of China): Yang Zhu, Lie zi, Zhuang zi. Petersburg: XXI vek.

Roth, Harold D. (1993). “Chuang tzu 莊子” in Michael Loewe (ed.), Early Chinese Texts: A Bibliographical Guide. Berkeley: Early China Special Monograph Series 2, pp. 56-66.

Shi ji 史記(1972). Ershisi shi 二十四史 series. Beijing: Zhonghua shuju.

Shanhaijing jianshu 山海經箋疏 (Explanatory notes and sub-commentary on the “Itineraries of Mountains and Seas”) [Hao Yixing 郝懿行 ed.], Sibu beiyao 四部備要 ed. (1927-1935). Shanghai: Zhonghua shuju.

Shangshu zhengyi 尚書正義 (True meaning of the "Book of Documents"), Sibu beiyao 四部備要 ed. (1927-1935). Shanghai: Zhonghua shuju.

Shuowen jiezi zhu 說文解子注 (1986). Shanghai: Shanghai guji chubanshe.

Taskin, Vsevolod S. (trans.) (1987). Go yu (Rechi tsarstv) (Guo yu [Speaches of the kingdoms]) Moscow: Nauka (GRVL).

Tkachenko, Grigory A. (trans.) (2001). Lyshi chun'tsyu: Vesny i oseni gospodina Lyuya (Lüshi chunqiu: Springs and autumns of Mister Lü). [Filosofskoe nasledie (Philosophical heritage) series, vol. 132]. Moscow: Mysl'.

Qiu Dexiu 邱德修(2003). Shangbo Chu jian Rong Cheng shi zhuyi kaozheng 上博楚簡 容成氏注譯考證 Commented translation and textual criticism of the Rong Cheng shi manuscript from the Chu bamboo strips of the Shanghai Museum). Taibei: Taiwan Guji.

Vyatkin, Rudolf V., and Vsevolod S.Taskin (trans.) (1972). Syma Tsyan' -- Istoricheskie Zapiski Shi tszi') (Sima Qian - Historical Records (Shi ji)). Vol. 1, Moscow: Nauka (GRVL).

Vyatkin, Anatoly R., ed. (2010). Syma Tsyan' -- Istoricheskie Zapiski Shi tszi' (Sima Qian - Historical Records Shi ji). Vol. IX. Moscow: Vostochnaya Literatura, 2010.

Watson, Burton (trans.) (1964). Han Fei Tzu: Basic Writings. New York: Columbia University Press.

Watson, Burton (trans.) (1968). The Complete Works of Chuang Tzu. New York - London: Columbia University Press.

Wilhelm, Richard (trans.) (1928). Früling und Herbst des Lü Bu We. Jena: Eugen Diderichs. 
Yan Ping et al. (1998). China in Ancient and Modern Maps. London: Sotheby's Publications, Philip Wilson Publishers Ltd.

Zhouli Zhengzhu 周禮鄭注 (“Zhou Rites” with commentaries by Zheng Xuan), Sibu beiyao 四部備要 ed. (1927-1935). Shanghai: Zhonghua shuju.

Zhuangzi jishi 莊子集釋 (Collected elucidations on Master Zhuang) [ed. Guo Qingfan 郭 慶藩] (1974). Taibei: Yiwen yinshuguan.

\section{SECONDARY SOURCES}

Allan, Sarah (1997). The Way of Water and Sprouts of Virtue, SUNY Series in Chinese Philosophy and Culture. New York: SUNY.

Allan, Sarah (2015). Buried Ideas: Legends of Abdication and Ideal Government in Recently Discovered Early Chinese Bamboo-Slip Manuscripts. Albany, NY: State University of New York Press.

Akin, Alexander and David Mumford (2012). "'Yu laid out the lands:' georeferencing the Chinese Yujitu [Map of the Tracks of Yu] of 1136", Cartography and Geographic Information Science, Vol. 39, No. 3, 2012, pp. 154-169.

Allan, Sarah (2017). "The Jishi Outburst Flood of 1920 BCE and the Great Flood Legend in Ancient China: Preliminary Reflections," Journal of Chinese Humanities 3: 23-34.

Anhui sheng wenwu gongzuodui 安徽省文物工作隊 (Anhui cultural relics working group) (1978). “Fuyang Shuanggudui Xi Han Ruyin hou mu fajue jian bao” 阜陽隻古堆 西漢汝陰侯發掘簡報 (An outline report on excavations at the Western Han tomb of the marquis of Ruyin at Shuanggudui, Fuyang), Wenwu 1978, no.8 : 12-30, 98-99.

Bai Yulan 白於藍 (2003). “'Rong Cheng shi’ bianlian wenti buyi” 《容成氏》編連問題 補議 (Complementary discussion of questions related to compilation of the Rong Cheng shi) in: Disi jie guoji zhongguo guwen zixue yantao huilunwen 第四屆國際中國古文字 學研討會論文集 Collected papers of the 4th International Workshop on the Study of Ancient Chinese Characters, The Chinese University of Hong Kong, 15-17.10.2003, pp. 301-308.

Bai Yulan 白於藍 (2004). “'Rong Cheng shi” bianlian wenti buyi”《容成氏》編連問題 補議 (Complementary discussion of questions related to compilation of the Rong Cheng shi). Huanan shifan daxue xuebao 華南師范大學學報 2004.4: 91-105. 
Batchelor, Robert (2013). "The Selden Map Rediscovered: A Chinese Map of East Asian Shipping Routes, c.1619," Imago Mundi 65.1: 37-63.

Batchelor, Robert (2014). London: The Selden Map and the Making of a Global City, 1549-1689. Chicago and London: The University of Chicago Press.

Birrell, Anne (1997). "The Four Flood Myth Traditions of Classical China."'T'oung Pao 83.1-3: 212-259.

Blakely, Barry B. (1999). "The Geography of Chu," in Cook, Constance A., and John S. Major (eds.), Defining Chu: Image and Reality in Ancient China. Honolulu: University of Hawai'i Press, pp. 9-20.

Boltz, William G. (1981). "Kung Kung and the Flood: Reverse Euhemerism in the Yao Tien.” T'oung Pao 67:3-5, pp.141-153.

Brashier Ken E. (2001-2002). "The Spirit Lord of Baishi Mountain: Feeding the Deities or Heeding the Yinyang?" Early China 26-27: 159-231.

Bray, Francesca (2007). "Introduction: The Powers of Tu," Graphics and Text in the Production of Technical Knowledge in China: the Warp and the Weft, eds. Francesca Bray, Vera Dorofeeva-Lichtmann and Georges Métailié. Leiden-Boston: Brill, pp. 1-78.

Chavannes, Edouard (1903). "Les deux plus anciens spécimens de la cartographie chinoise", BEFEO 3 : 214-247.

Chemla, Karine, Alexeï K. Volkov et Viéra V. Lichtmann, eds. (1991). Extrême-Orient Extrême-Occident, vol. 13: Modèles et structures des textes chinois anciens: les formalistes soviétiques en sinologie.

Chen Jian 陳劍(2004). “Shangbojian 'Rong Cheng shi' de zhujian pinhe yu bianlian wenti xiaoyi”上博簡《容成氏》的竹簡拼合與編連問題小議 (A brief discussion of questions related to composition and compilation of the Rong Cheng shi manuscript from the Shanghai museum bamboo strips) in: Shangboguan cang Zhanguo Chu zhushu yanjiu xubian 上博館藏戰國楚竹書研究續編 (A sequel to the "Studies of Chu bamboo strips of the Warring States period from the Shanghai Museum”), eds. Zhu Yuanqing 朱淵清 and Liao Mingchun 墋名春, Shanghai: Shanghai shudian, pp. 327-334.

First published under a slightly different title "Shangbo jian 'Rong Cheng shi' de pinhe yu bianlian wenti" 上博簡《容成氏》的拼合與編連問題 (Questions related to the composition and compilation of the Rong Cheng shi manuscript from the Shanghai museum bamboo strips) at the Jianbo yanjiu 簡帛研究 (Bamboo and Silk forum), 9.01.2003 http://www.jianbo.org/Wssf/2003/chenjian02.htm https://wenku.baidu.com/view/edfa06ebf8c75fbfc77db2e9.html

Chen Ligui 陳麗桂(2004). “Tan 'Rong Cheng shi’ de liejian cuozhi wenti” 談《容成 氏》的列簡錯置問題 (Discussing questions related to an alternative sequence of srtips of the Rong Cheng shi manuscript), in: Zhu Yuanqing 朱淵清 and Liao Mingchun 羿名 
春(eds.), Shangbo guan cang Zhanguo Chu zhushu yanjiu xubian 上博館藏戰國楚竹書 研究續編 (A sequel to the "Studies of Chu bamboo strips of the Warring States period from the Shanghai Museum”). Shanghai: Shanghai shudian, pp. 335-342.

Chen Wei 陳偉(2003). “Zhushu 'Rong cheng shi' suo jian de Jiu zhou” 竹書《容成氏》 所見的九州 (The Nine Provinces found in the Rong Cheng shi manuscript on bamboo strips). Zhongguo shi yanjiu 中國史研究 (Studies in Chinese history) 2003.3: 41-48.

Cheng Yuanmin 程元敏 (2004). “Tianming Yu pingzhi shuitu” 天命禹平治水土 (The Heavenly Mandate and "levelling and ordering waters and lands" by the Emperor $\mathrm{Yu}$ ), in Shangbo guan cang Zhanguo Chu zhushu yanjiu xubian 上博館藏戰國楚竹書研 續編 (A sequel to the "Studies of Chu bamboo strips of the Warring States period from the Shanghai Museum”), eds. Zhu Yuanqing 朱淵清 and Liao Mingchun 翏名春. Shanghai: Shanghai shudian, pp. 331-326.

Cook, Constance A., and John S. Major (eds.) (1999). Defining Chu: Image and Reality in Ancient China. Honolulu: University of Hawai'i Press.

Cook, Constance A. and Zhao Lu (2017). Stalk Divination: A Newly Discovered Alternative to the I-Ching. Oxford: Oxford University Press.

Cook, Constance A. and Luo Xinhui (2017). Birth in Ancient China: A Study of Metaphor and Cultural Identity in Pre-Imperial China. Albany: SUNY.

Cullen, Christopher (2017). Heavenly Numbers: Astronomy and Authority in Early Imperial China. Oxford: Oxford Universtiy Press.

Dan Yuchen 單育辰 (2010). “Rong Cheng shi zatan”《容成氏》杂谈 [三则] (Various discussions of the Rong Cheng shi), in: Jiangbo yanjiu 2007 簡帛研究 2007 (Bamboo and silk studies 2007), Guilin: Guangxi shifan daxue chubanshi 广西师范大学出版社, pp. 37-44.

Dan Yuchen 單育辰 (2016). Xinchu Chu jian 'Rong Cheng shi' yanjiu 新出楚簡《容成 氏》研究 . Beijing: Zhonghua shuju.

De Weerdt, Hilde (2009). "Maps and Memory: Readings of Cartography in Twelfth- and Thirteenth-Century Song China", Imago Mundi 61.2: 145-167, DOI: $10.1080 / 03085690902923572$

Dorofiéiéva-Lichtmann, Viéra (1991). "Vents des royaumes' (Guo feng): un schéma géographique." Extrême-Orient Extrême-Occident 13: Modèles et structures des textes chinois anciens: les formalistes soviétiques en sinologie, eds. Karine Chemla, Alexei Volkov and Vera Dorofeeva-Lichtmann, pp. 58-91.

http://www.persee.fr/web/revues/home/prescript/article/oroc_0754-5010_1991_num_13_13_1043 
Dorofeeva-Lichtmann, Vera V. (1995). "Conception of Terrestrial Organization in the Shan hai jing." BEFEO 82: 57-110.

http://www.persee.fr/web/revues/home/prescript/article/befeo 0336-1519 1995 num 8212297

Dorofeeva-Lichtmann, Vera V. (1996). "Political Concept Behind an Interplay of Spatial 'Positions'." Extrême-Orient Extrême-Occident 18 (1996): Disposer pour dire, placer pour penser, situer pour agir, eds. Karine Chemla and Michael Lackner, pp. 9-33. http://www.persee.fr/web/revues/home/prescript/article/oroc 0754-5010 1996 num 18181016

Dorofeeva-Lichtmann, Vera V. (2003a). "Mapping a 'Spiritual' Landscape: Representing Terrestrial Space in the Shan hai jing," in: Political Frontiers, Ethnic Boundaries, and Human Geographies in Chinese History, eds. Nicola di Cosmo and Don Wyatt. London: Curzon - Routledge, pp. 35-79. https://www.academia.edu/22611459

Dorofeeva-Lichtmann, Vera V. (2003b). "Text as a Device for Mapping a Sacred Space: A Case of the Wu zang shan jing ('Five Treasuries: The Itineraries of Mountains')," in: Creating and Representing Sacred Spaces. Göttinger Beiträge zur Asienforschung 2-3 (2003), guest eds. Michael Dickhardt and Vera Dorofeeva-Lichtmann, pp. 147-210. https://www.academia.edu/22610327

Dorofeeva-Lichtmann, Vera V. (2005-2006). "Where is the Yellow River Source? A Controversial Question in the Early Chinese Historiography." Oriens Extremus 45, pp. 68-90.

http://oriens-extremus.org/de/archive/

www.pucsp.br/pos/cesima/v.4/veralichtmann.pdf

Dorofeeva-Lichtmann, Vera V. (2006). "Formation and evolution of the conception of the 'Nine Provinces' (Jiu zhou): a Critical evaluation of the early sources," in Gao Xuan, Hans-Ulrich Vogel and Christine Moll-Murata (eds.), Studies on Ancient Chinese Scientific and Technical Texts. Proceedings of the 3rd ISACBRST (The $3^{\text {rd }}$ International Symposium on Ancient Chinese Books and Records of Science and Technology, Tübingen, 31.03-04.04.2003). Zhengzhou: Daxiang chubanshe, pp. 1-23.

Dorofeeva-Lichtmann, Vera V. (2007). "Mapless Mapping: Did the Maps of the Shanhai jing Ever Exist?" in Graphics and Text in the Production of Technical Knowledge in China: the Warp and the Weft, eds. Francesca Bray, Vera Dorofeeva-Lichtmann and Georges Métailié. Leiden-Boston: Brill, pp. 217-294. https://www.academia.edu/22611885

Dorofeeva-Lichtmann, Vera V. (2010). "The Rong Cheng shi version of the "Nine Provinces': Some Parallels with Transmitted Texts." East Asian Science, Technology and Medicine 32: 13-58.

http://www.eastm.org/index.php/journal/article/view/347

https://www.academia.edu/22612338

Dorofeeva-Lichtmann, Vera (2015). "Healing Plants in the Spiritual Landscape of the Shanhai jing (Itineraries of Mountains and Seas, comp. $1^{\text {st }}$ c. BC." In: Materia Medica and Pharmacy: Medicinal Virtues to the Active Principles of Plants, eds. Marcia Ferraz 
and Patricia Aceves, special issue of the Circumscribere [International Journal for the History of Science] 16 (2015), 103-122.

Dorofeeva-Lichtmann, Vera V. (2019 [rev. 2009]). "Ritual Practices for Constructing Terrestrial Space (Warring States-Early Han)," in: HdO Early Chinese Religion. Part One: Shang through Han (1250 BC - 220 AD), eds. John Lagerwey and Marc Kalinowski. Leiden - Boston: Brill, pp. 595-644. https://www.academia.edu/22612032

Dorofeeva-Lichtman, Vera V. (2019). "'Inversed Cosmographs' in Late East Asian Cartography and the Atlas Production Trend," in: East-West Encounter in the Science of Heaven and Earth 天と地の科学, eds. Tokimasa Takeda 武田時昌 and Bill M. Mak 麥 文虎. Kyoto: Institute for Research in Humanities, Kyoto University 京都大學人文科學 研究所, pp. 144-174. https://www.academia.edu/39008442

[The complete volume can be downloaded http://www.billmak.com/storage/Mak_Takeda\%202019.pdf http://www.billmak.com/astronomy/

Dorofeeva-Lichtmann, Vera, and Alexei Volkov. "Formal Approaches to Studies of Traditional Maps of East Asia: State of the Art and General Remarks," paper presented at the Panel "Formal Approaches to Studies of Traditional MAPS OF EAST AsiA", $15^{\text {th }}$ International Conference on the History of Science in East Asia (ICHSEA), 19-2308.2019, Chonbuk National University, Jeonju, Republic of Korea, http://ichsea2019.org/program.php

(article "Typology of East Asian maps and Formal Approaches to their Study" in preparation for the East Asian Science Technology and Medicine journal www.eastm.org)

Du Yong 杜勇 (2008). “Lun Yugong Liangzhou xiangguan wenti” 論《禹貢》梁州相關 諸問題 (Some Opinions on Liangzhou in Yugong), Tianjin Shifan Daxue xuebao [shihui kexueban] 天津師范大學學報 [社會科學版] / Journal of Tianjin Normal University [Social Sciences], 2008, N², Sum N 197, pp. 37-41.

Du Yong 杜勇 (2010). “Ju guo wang nian bian” 莒國亡年辨 (Discussion of the disappearance of the Ju kingdom). Guanzi xuekan 管子學刊 (Guanzi journal) №3, pp. 115-116.

van Ess, Hans (1993). Politik und Gelehrsamkeit in der Zeit der Han: Die Alttext / Neutext-Kontroverse. Wiesbaden: Harrassowitz.

Henderson, John. B. (1984). The development and decline of Chinese cosmology. New York: Columbia University Press.

Henderson, John. B. (1994). "Chinese cosmographical thought: the high intellectual tradition," in Cartography in traditional East and Southeast Asian societies (The History of Cartography, vol. II.2), eds. John B. Harley and David Woodward. Chicago - London: Chicago University Press, pp. 203-227. 
Fan Guodong 凡國棟 (2007). “Rong Cheng shi Jiuzhou deming yuanyin shitan” 《容成 氏》九州 得名原因試探 (Discussion of the origins of names of the 'Nine Provinces' of the Rong Cheng shi), in: Chudi jianbo sixiang yanjiu 楚地簡帛思想研究 (Chu bamboo and silk manuscripts thought studies), vol. 3, Wuhan: Hubei jiaoyu chubanshi 湖北教育 出版社, pp. 212-219.

Gentz, Joachim, and Dirk Meyer, eds. (2015). Literary Forms of Argument in Early China. Leiden: Brill.

Grebnev, Yegor (2020). "Aural-mnemonic architectonics of ancient Chinese philosophical texts," Monumenta Serica, 68.2: 289-314.

Gu Jiegang 顧頡岡U(1933). “Zhou yu yue de yanbian.” 州與䓂的演變 (Developing on the [Nine] Provinces and [Five] Peaks). Shixue nianbao (chubian) 史學年報初編 (Yearly journal on historical studies [first edition]) 1.5: 11-33.

Gu Jiegang 顧頡剛, Tong Shuye 童書業 (1936). "Handai yiqian zhongguoren de shijie guannian yu yuwai jiaotong de gushi” 漢代以前中國人的世界觀念與域外交通的故事 (Essay on the view of the world by the pre-Han Chinese and their communication with outside lands), Yugong ban yue kan 禹貢半月刊/The Chinese Historical Geography (semi-monthly Magazine) 5.3-4 (April): 97-120.

Guo Dewei 郭德維 (1999). Chu du Ji'nancheng fuyuan yanjiu 楚都紀南城復原研究 (Rehabilitating study of the Chu capital at Ji'nancheng). Beijing: Wenwu chubanshe.

Guo Yongbing 郭永秉 (2006). “Cong Shangbo Chu jian Rong Cheng shi de 'you Yu tong' shuodao Tan Yu shishi de yiwen” 从上博楚简《容成氏》的 “有虞迵” 说到唐虞 傳說的 疑问 (Elucidating on some controversial questions of narratives related to Tang $\mathrm{Yu}$ (= Yao and Shun) from the point of view of the "Youyu tong" (Youyu = Shun yielded the throne) in the Rong Cheng shi manuscript from the Shanghai Museum Chu bamboo strips), Chutu wenxian yu guwenzi yanjiu 出土文献与古文字研究 1: 295-312.

First published under a slightly different title "Cong Shangbo Chu jian Rong Cheng shi de 'you Yu tong' shuodao Tan Yu shishi de yiwen” 从上博楚简《容成氏》的 “有虞迵” 说到唐虞史事的疑问 (Elucidating on some controversial questions of narratives related to Tang $\mathrm{Yu}$ (= Yao and Shun) from the point of view of the 'Youyu tong' (Youyu = Shun yielded the throne) in the Rong Cheng shi manuscript from the Shanghai Museum Chu bamboo strips) at the Jianbo yanjiu 簡帛研究 (Bamboo and Silk forum), 7.11.2005 http://www.jianbo.org/admin3/2005/guoyongbing001.htm http://www.jianbo.org/showarticle.asp?articleid=1169

and 4.9.2005 http://www.jianbo.org/showarticle.asp?articleid=1158

Guo Yongbing 郭永秉 (2008). Di xi xin yan 帝系新研 (New studies of the legendary emperors). Beiing: Beijing daxue, esp. pp. 43-56.

Hein, Anke (2019). "Concepts of 'Authenticity' and the Chinese Textual Heritage in Light of Excavated Texts." In: China and the World - the World and China, Essays in 
Honour of Rudolf G. Wagner, eds. Barbara Mittler, Joachim \& Natasha Gentz and Catherine Vance Yeh (Volume 1: Transcultural Perspectives on Pre-Modern China, ed. Joachim Gentz), DeUtSche OSTASIENSTUdien 37, Gossenberg: Ostasien Verlag, pp. 3763.

Hofmann, Martin (2007). Reconsidering the spatial order of the Great Yu. Song commentaries on the Yugong. Diss. Würzburg Univ.

Huang Ren'er 黃人二 (2005). “Shangbo Chujian Rong Cheng shi suoshu zhi Jiuzhou ji xiangguan wenti tanyan”上博楚簡《容成氏》所述之九州及相關問提探研 (Investigation of the "Nine Provinces" and related issues in the Rong Cheng shi manuscript from the Shanghai collection of bamboo slips), in: Chutu wenxian lunwenji 出土文獻論文集 (Collection of papers on Chu excavated documents). Taibei: 高文出版 社 Gaowen chubanshe, 145-157.

Huang Ru-Xuan 黃儒宣 (2019). “Xi Han zaoqi de tiandi moxing - yi Mawandui boshu 'Digangtu’ ji ‘Kanyu’ wei zhongxin” 西漢早期的天地模型一以馬王堆帛書《地剛圖 》及《堪锤》為中心 (The Heaven-and-Earth Model in Early Western Han Dynasty: Highlighting the Mawangdui Silk Texts Digang Graph and Kanyu). Zhongyang yanjiuyuan lishi yuyan yanjiusuo jikan 中央研究院歷史語言研究所集刊 19.4: 682-732.

Jao Tsung-I (Rao Zongyi) 饶宗颐 (2006). “You Zun Lu shi tandao shang hai zushu (er) de Rong Cheng shi - Jianlun qi yu Mojia guanxi ji qita wenti” 由尊卢氏谈到上海竹书 （二）的《容成氏》一 兼论其与墨家矢系及其它问题 (Discussing the Rong Cheng shi from the Shanghai collection of bamboo slips from the point of view of Zun Lu shi correlated dicsussion of its relation to the Moist school and other questions), Jiuzhou xuelin 九州学林 (Forest of the "Nine Provinces" studies) 春李卷 mid-spring issue [Fudan Daxue chubanshe 复旦大学出板社], pp. 2-15.

Jiang Guanghui 姜廣輝, Fu Zan 付贊, Qiu Mengyan 邱夢燕 (2013). “Qinghuajian 'Qi Ye' wei weizuo kao"” 清華簡《者夜》為偽作考 / “Research into the fabrication of the 'Qi Ye' manuscript among the Qinghua Collection of Bamboo Strips." Gugong Bowuyuan yuankan 故宮博物院院刊 2013, N 4, Sum 168, pp. 86-94, abstract pp. 160161.

Kern, Martin (2017). "Language and the Ideology of Kingship in the 'Canon of Yao", in: Origins of Chinese Political Philosophy Studies in the Composition and Thought of the Shangshu (Classic of Documents), STUdiEs IN THE History OF CHINESE TeXTS, vol. 8, eds. Martin Kern and Dirk Meyer. Leiden - Boston, Brill, pp. 23-61.

Kern, Martin (2019). “'Xi shuai’ 蟋蟀 ('Cricket') and its Consequences: Issues in Early Chinese Poetry and Textual Studies.” Early China 42: 39-74.

Khayutina, Maria (2020). "Glückverheißende Omina und weltliche Tugenden der, zu ‘Königen Erhobenen': Ein Nachruf für Kaiser Wu der Liang-Dynastie im Buch Jinlouzi 
(6. Jh.)." In: Aus geteilten Zeiten: Studien zur Nanbeichao-Periode. Geburtstagsgabe für Shing Müller 宋馨, ed. Roderich Ptak. Gossenberg: Ostasien-Verlag, 2020, pp. 89-128.

Kryukov, Michail V. (1966). "Hsing and Shih.” Archiv Orientalni 34: 535-553.

Kryukov, Michail V. (1972). Sistema rodstva kitaitsev (The system of kinship of the Chinese). Moscow: Nauka, GRVL.

Lai Guolong and Q. Edward Wang (2017). "Manuscript Culture in Early China: Editors' Introduction." Chinese Studies in History, 50:3: 167-171.

Lawton, Thomas (ed.) (1991). New Perspectives on Chu Culture during the Eastern Zhou Period. Washington: Arthur M.Sackler Gallery (Smithsonian Institution), distributed by Princeton University Press.

Ledyard, Gari (1994). "Cartography in Korea", in: The History of Cartography, Vol.II.2: Cartography in the Traditional East and Southeast Asian Societies, eds. J.B. Harley and David Woodward. Chicago -- London: The University of Chicago Press, pp. 235-345, wheel maps: 256-267.

Lewis, Marc Edward (2006). The Flood Myths of Early China. New York: SUNY.

Li Ling 李零 (1985). Changsha Zidanku zhanguo Chuboshu yanjiu 長沙子彈庫戰國楚 帛書研究. Beijing: Zhonghua shuju.

Li Ling 李零 (1991). “Chuboshu yu shitu” 楚帛書與式圖. Jiang Han kaogu 江漢考古 1991.1: 59-62.

Li Ling 李零 (2000). Zhongguo fangshu kao 中國方術考. Beijing: Dongfang chubanshe (revision of 1993, Beijing Renmin Zhongguo chubanshe).

Li Ling 李零 (2003). "Sandai kaogu de lishi duanxiang: cong zuijin fabiao de Shangbo jian 'Rong Cheng shi', Bin Gong xu he Yu Qiu zhuqi xiangdao de” 三代考古的歷史斷 想：從最近發表的上博簡《容成氏》、Bin 公昷和虞逑諸器想到的 (Reflections on the history of archeology of the Three Dynasties : from the point of view of the recently discovered Rong Cheng shi manuscript from the Shanghai Museum bamboo slips, the Bin Gong $x u$ tureen and the Yu Qiu bronze vessels). Zhongguo xueshu 中國學術 (Methodology of Chinese studies) 2003.2: 188-213.

Li Ling 李零 (2013). Chuboshu yanjiu 楚帛書研究. Shanghai: Zhongxi shuju.

Li Ling 李零 (2017). Zidanku boshu 子彈庫帛書 . Beijing: Wenwu chubanshe, 2 vols. 
Li Ling 李零 (2020). The Chu Silk Manuscripts from Zidanku, Changsha (Hunan Province), Vol.1, Translated and edited by Lothar von Falkenhausen. Hong Kong: The Chinese University Press.

Li Shoukui 李守奎, Qu Bing 曲冰 and Sun Weilong 孫偉龍(2007). Shanghai bowuguan cang Zhanguo Chu zhushu (vol. 1-5) wenzi bian 上海博物館藏戰國楚竹書(一-五) 文字 編 (List of characters found in Chu bamboo strips of the Warring States period from the Shanghai Museum), vols 1-5. Beijing: Zuojia chubanshe, 181-190.

http://www.bsm.org.cn/show_article.php?id=884

Liu Dunzhen 刘敦桢 (1957). Zhongguo zhuzhai gaishuo 中国住宅概说 (Introduction to Chinese Dwellings). Beijing: Jianzhu Gongchen Chubanshe 建筑工程出版社 (French translation 1981).

Liu Lexian 劉樂賢 (13.01.2003). “Du Shangbo jian 'Rong Cheng shi’ xiao zha”讀上博 簡《容成氏》小札. http://www.jianbo.org/Wssf/2003/liulexian02.htm.

Major, John S. (1984). "The Five Phases, Magic Squares and Schematic Cosmography," in Henry Rosemont (ed.), Explorations in Early Chinese Cosmology. Chico: Scholar Press, pp. 133-166.

Mathieu, Rémi (1992). "Yu le Grand et le mythe du Déluge dans la Chine ancienne." T'oung Pao 78: 162-190.

Nakamura Hirosi (1947). "Old Chinese Maps Preserved by the Koreans." Imago Mundi 4: 3-22.

Needham, Joseph, and Wang Ling (1959). Science and Civilisation in China, Vol. III: Mathematics and the Sciences of the Heaven and the Earth (chapter: "The Sciences of the Earth", pp. 497-490). Cambridge: Cambridge University Press.

Nickel, Lucas (2005). "Locating Luoyi: Textual and archeological evidence of the Western Zhou residence," in Christelle Maréchal and Yau Shun-chiu (eds.), Proceedings of the International Symposium The Visual World of China. Paris: Editions Languages Croisés (special issue $\mathrm{n}^{\circ}$ 2), pp. 85-102.

Niu Xinfang 牛新房 (2010). “Chu zhuzhu Rong Cheng shi buyi” 楚竹書《容成氏》補 議 (Complementary discussion of a Chu bamboo manuscript Rong Cheng shi). Zhongguo lishi wenwu 中國歷史文物 2010.4: 73-77.

Nylan, Michael (comprises a commented translation with the original text) (1992). The Shifting Center: The Original "Great Plan" and Later Readings. Nettetal: Steyler Verlag. 
Oh Sang-Hak (2008). "Circular World Maps of the Joseon Dynasty: Their Characteristics and Worldview," Korea Journal 48-1: 8-45.

Pankenier, David W. (2013). Astrology and Cosmology in Early China: Conforming Earth to Heaven. Cambridge: Cambridge Universtity Press.

Papelitzky, Elke. (2021). "Sand, Water, and Stars: Chinese Mapping of the Gobi and Taklamakan Deserts" T'oung Pao, Vol. 107, no. 3-4: 376-416.

Pines, Yuri (2005). "Disputers of Abdication: Zhanguo Egalitarianism and the Sovereign's Power." T'oung Pao 91.4-5: 243-300.

Pines, Yuri (2005-2006). "Bodies, Lineages, Citizens, and Regions: a Review of Mark Edward Lewis' The Construction of Space in Early China.' Early China 30: 155-188.

Pines, Yuri (2010). "Political Mythology and Dynastic Legitimacy in the Rong Cheng shi Manuscript.” Bulletin of SOAS 73.3 (2010): 1-27.

Qu Wanli 屈萬里(1964). “Lun Yugong zhucheng de shidai.”論禹貢著成的時代 (Discussing the time of creation of the Yugong). Zhongyang Yanjiuyuan Lishi Yuyan yanjiusuo jikan 中央研究院歷史語言研究所集刊/Bulletin of the Institute of history and Philology (Academia Sinica) 35: 53-86.

Rykov, Stanislav (2016). "The 'School of Structural Analysis' in Modern Russian Sinology." Journal of World Philosophies, vol. 1 (Winter 2016): 27-40. http://scholarworks.iu.edu/iupjournals/index.php/jwp• doi:10.2979/jourworlphil.1.1.03

Shatzman Steinhardt, Nancy (1999 [repr. of 1990]). Chinese Imperial City Planning, Honolulu: University of Hawai'i Press.

Shaughnessy, Edward. (1993). I Chou shu. In: Early Chinese Texts: A Bibliographical Guide, ed. by Michael Loewe. Berkeley: Early China Special Monograph Series 2, pp. 229-233.

Shaughnessy, Edward. (2018). Review: "Origins of Chinese Political Philosophy: Studies in the Composition and Thought of the Shangshu (Classic of Documents). Edited by Martin KERN and Dirk MEYER. Leiden and Boston: Brill, 2017. Pp. vi+508.” 饒宗頣國 學院院刊 / Bulletin of the Jao Tsung-I Academy of Sinology, vol. 5 (May 2018): 417445.

Shen Jianhua 沈建華 (2004). “Chu jian 'Rong Cheng shi' zhouming yu buci jinwen diming, 楚簡《容成氏》州名与卜辭金文地名 (Provinces names found in the Rong Cheng shi manuscript on bamboo strips from Chu and placenames found in inscriptions on oracle bones and bronze vessels), Guwenzi yanjiu 古文字研究 (Studies of the ancient Chinese characters) 25: 328-333. 
Shou Bin 守涁 (2011). “Cong Qinghua jian Chu ju tan 'x Ying”” 從清華簡《楚居》談 “x 虽” (Discussing “x Ying” [capital] from the perspective of the "Chu Settlements" [manuscript]). Chu wenhua yanjiu lunji 楚文化研究論集 10: 94-100.

Staack, Thies (2010). "Reconstructing the Kongzi Shilun: From the Arrangement of the Bamboo Slips to a Tentative Translation." Asiatische Studien-Etudes Asiatiques 64.4: 857-906.

Staack, Thies (2016). "Reconstruction of Early Chinese Bamboo and Wood Manuscripts: A Review (1900-2010)." CSMC (Centre for the Study of Manuscript Cultures) Occasional Paper No. 5 (published in April 2016) http://www.manuscript-cultures.unihamburg.de/papers_e.html.

Strassberg, Richard. 2002. A Chinese Bestiary: Strange Creatures from the Guideways Throught Mountains and Seas. Berkeley - Los Angeles - London: University of California Press.

Su Jianzhou 蘇建洲 (2003). ““Rong Cheng shi” yishi” 《容成氏》譯釋 (Translation and elucidation of the Rong Cheng shi), in: Shanghai bowuguan cang Zhanguo Chu zhushu (vol. 2) 《上海博物館藏戰國楚竹書 $(二)$ 》讀本 (Reading of the Chu bamboo strips of the Warring States period from the Shanghai Museum [vol. 2]), eds. Ji Xusheng 季旭昇, editor-in-chief, Chen Meilan 陳美蘭, Su Jianzhou 蘇建洲, Chen Jialin 陳嘉凌. Taibei: Wanjuanlou, pp. 103-182.

First published under a slightly different title “Rong Cheng shi jianshi” 《容成氏》柬釋 (Selected elucidations on the Rong Cheng shi) at the Jianbo yanjiu 簡帛研究 (Bamboo and Silk forum), 29.03.2003. http://www.jianbo.org/Wssf/2003/sujianzhou15.htm

Sun Feiyan 孫飛燕 (2010). “Rong Cheng shi yanjiu zongshu”《容成氏》研究綜述 (Summing up studies of the Rong Cheng shi). Zhongguoshi yanjiu dongtai 中國史研究 動態 2010.7: 12-17.

Sun Weilong 孙伟龙 and Li Shoukui 李守奎 (2008). “Shangbojian biaozhi fuhao wuti” 上博简标识符号五题 (Five questions concerning symbols and signs in the Shanghai collection of bamboo slips), Jianbo 简帛 (Bamboo and silk) $\mathrm{N}^{\circ} 3$ [Shanghai guji chubanshe 上海古籍出版社], 181-190.

Taniguchi Mitsuru 谷 $\square$ 滿 (2011). "Shi lun Qinghua jian Chu ju duiyu Chuguo lishi dili yanjiu de yingxiang” 試論清華簡《楚居》對於楚國歷史地理研究的影響 (Examining the influence of the "Chu Settlements" [manuscript] from the Tsinghua [collection of] bamboo slips on studies of historical geography of the Chu Kingdom), trans. Chen Wei 陳偉. Chu wenhua yanjiu lunji 楚文化研究論集 10: 23-30. 
Thote, Alain (2001-2002). "Review: Cook, Constance A., and John S. Major, eds. Defining Chu: Image and Reality in Ancient China. Honolulu: University of Hawai'i Press, 1999." Early China 26-27: 257-284.

Tkatchiénko, Grigoriï A. (1991). "Sur la composition du Shi'er ji dans le Lü shi chunqiu (Printemps et automnes de Lü." In Extrême-Orient Extrême-Occident 13 (1991): Modèles et structures des textes chinois anciens: les formalistes soviétiques en sinologie, eds. Karine Chemla, Alexei Volkov, and Vera Dorofeeva-Lichtmann, pp. 121-126.

Tseng, Lan-ying Lilian 曾藍瑩 (2003). "Visual Replication and Political Persuasion: The Celestial Image in Yuan Yi's Tomb" / "Shijue fuzhi yu zhengzhi shuofu: Bei Wei Yuan Yi mu tianxiang jiexi” 視覺複製與政治說服：北魏元入墓天象解析 (summary). In: Between Han and Tang: Visual and Material Culture in a Transformative Period / 漢唐 之間的視覺文化與物質文化, ed. Wu Hung 巫鴻. Beijing: Wenhua, pp. 377-424.

Unno, Kazutaka (1981). "The Origin of the Cartographical Symbol Representing Desert Areas." Imago Mundi 33: 82-87.

Vogelsang, Kai (2002). "Inscriptions and Proclamations: On the Authenticity of the 'gao' Chapters in the Book of Documents." BMFEA 74: 138-209.

Vogelsang, Kai (2017). "Competing Voices in the Shangshu", in: Origins of Chinese Political Philosophy Studies in the Composition and Thought of the Shangshu (Classic of Documents). Studies In THE History OF Chinese TeXTs, vol. 8, eds. Martin Kern and Dirk Meyer. Leiden - Boston, Brill, pp. 62-105.

Volkov, Alexei (2015). "Pre-colonial Vietnam in Chinese and Western maps: A Revisit," paper presented at the Panel "Re-discovered Maps of East and South-East Asia", $14^{\text {th }}$ International Conference on the History of Science in East Asia (ICHSEA), 610.07.2015, EHESS, Paris.

Volkov, Alexei (2019) "Formal Approaches to Studies of Traditional Maps of East Asia: State of the Art and General Remarks, Part 2," see Dorofeeva-Lichtmann, Vera, and Alexei Volkov (2019).

Wang Chengzu 王成組. [1982] 1988. Zhongguo dilixueshi: Xian Qin zhi Ming dai 中國 地理學史, 先秦至明代. Beijing: Shangwu yinshuguan.

Wang Kunpeng 王坤鵬 (15.10.2010). “Chujian Rong Cheng shi shidi wenti yanjiu pingyi” 楚簡《容成氏》史地問題研究評議 (A critique of studies of historical and geographical questions in the Rong Cheng shi manuscript on bamboo strips from Chu). Bamboo and Silk Manuscripts [BSM] (Wuhan Daxie jianbo yanjiu zhongxin 武漢大學簡 帛研究中心 / Center for bamboo silk manuscripts of Wuhan University http://www.bsm.org.cn/show_article.php?id=1322 
Wang Yong 王庸 (1998 [repr. of 1938]). Zhongguo dilixue shi 中國地理學史 (History of Chinese geography). Shanghai: Commercial Press. 
Wu Chia-Yun 吳佳芸 (2021). “Yi-Xing’s Large-Scale Gnomonic Survey and Mapping of Terrestrial Realm", paper presented at the colloquium of the Department III of the Max Planck Institute for the History of Science, Berlin (06.10.2021).

Xin Deyong 辛德勇. Xin Deyong shuo Zhongguo lishi dili: yanmo de guowang 辛德勇說 中國歷史地理 : 酒沒的過往 (Xin Deyong elucidates on historical geography of China: neglected past). Shenyang: Wanjuan, 2017.

Xu Quansheng 許全胜(14.01.2003). “Rong Cheng shi’ bushi’《容成氏》補釋” (Complementary elucidations on the Rong Cheng shi) http://www.jianbo.org/Wssf/2003/xuquansheng01.htm

Yan Changgui 晏昌貴 (2004a). “'Shanghai bowuguan cang Zhanguo chu zhushu (2)” zhong 'Rong Cheng shi' Jiuzhou jianshi” 《上海博物館藏戰國楚竹書 $(二)$ 》中《容成 氏》九州柬釋. Wuhan daxue xuebao 武漢大學學報. 57.4 (July): 503-506.

First published under a slightly different title "Shangbo jian “Rong Cheng shi” Jiuzhou jianshi” 上博簡《容 成氏》九州柬釋 at the Jianbo yanjiu 簡帛研究 (Bamboo and Silk forum), 6.04.2003 http://www.jianbo.org/Wssf/2003/yanchanggui01.htm

Yan Changgui 晏昌貴 (2004b). “'Rong Cheng shi' zhong de 'Yu zheng” 《容成 氏》中的“禹政”,” in Zhu Yuanqing 朱淵清 and Liao Mingchun 翏名春 (eds.), Shangbo guan cang Zhanguo Chu zhushu yanjiu xubian. 上博館藏戰國楚竹書研 續 編. Shanghai: Shanghai shudian, pp. 358-366.

Yan Shixuan (Yen Shih-Hsuan) 顏世鉉. “Shangbo Chu zhushu sanlun”上博楚竹書 散論 (Dispersed discussion of the Chu bamboo manuscripts of the Shanghai Museum), Jianbo yanjiu 簡 帛 研 究 (Bamboo and Silk forum), 20.02.2003 http://www.jianbo.org/Wssf/2003/yuanshixuan02.htm

Yan Shixuan (Yen Shih-Hsuan) 顏 世 鉉. 戰國秦漢簡帛校讀方法研 / Text-critical Approaches to the Bamboo and Silk Manuscripts of the Warring States, Qin, and Han Periods. 臺灣大學中國文學研究所學位論文. Taipei: Taibei daxue, 2012 (Ph.D. Diss.).

Yee, Cordell D.K. "Reinterpreting Traditional Chinese Geographical Maps." In: The History of Cartography, Vol. II.2: Cartography in the Traditional East and Southeast Asian Societies, eds. John B. Harley and David Woodward. Chicago and London: The University of Chicago Press, 1994, pp. 35-70.

Yi Ch'an 李燦 [Chan Lee] (1976). “Han'guk ûi ko segye chido” 韓國의古世界地圖 (Old Korean world maps), Han'guk Hakpo 韓國學報 2: 47-66 (six map plates).

Yi Desheng 易德生 (2006). “Shangbo Chu jian 'Rong Cheng shi' Jiuzhou chuyi” 上博 楚簡《容成氏》九州㫚議 (Modest reflections on the 'Nine Provinces' in the Rong Cheng shi manuscript from the Chu bamboo strips of the Shanghai Museum). Jiang Han luntan 江漢論壇 (Jiang Han Tribune) 2006.5: 106-108.

First published under a slightly different title "Shangbo Chu jian 'Rong Cheng shi' 'Ju zhou' he 'Jing zhou‘ xinyi”上博楚簡《容成氏》‘营州’ 和 ‘競州’ 新議’ (New discussion of Ju province and Jing province found in the Rong Cheng shi manuscript from the Chu bamboo strips of the Shanghai Museum) at the at the Jianbo yanjiu 簡帛研究 (Bamboo and Silk forum), 5.02.2006, dowloaded from http://www.jianbo.org/admin3/list.asp?id=1461

Yi Desheng 易德生 (2009). “Cong Shangbo Chu jian 'Rong Cheng shi' Jiuzhou kan 'Yu gong' de chengshu niandai” 從上博楚簡《容成氏》九州看《禹貢》的成 
書 年代” (Regarding the period of composition of the Yu gong from the perspective of the 'Nine Provinces' of the Rong Cheng shi manuscript from the Chu bamboo strips of the Shanghai Museum), Jiang Han luntan 江漢論壇 (Jiang Han Tribune) 2009.12: 77-80. First published under a slightly different title "Rong Cheng shi' 'Ju zhou' wei 'Xu zhou' buzhu” 《容成 氏》 ‘莒州” 為 “徐州” 補注 (Additional comments to the identification of Ju province found in the Rong Cheng shi with Xu province') at the at the Jianbo yanjiu 簡帛研究 (Bamboo and Silk forum), 27.03.2006 http://www.jianbo.org/admin3/list.asp?id=1481

Yin Difei 陰涤非 (1978). “Xi Han Ruyin hou mu chutu de zhanpan he tianwe yiqi” 西漢 汝陰候墓出土的占盤和天文儀器 (The divining board and the astronomical instrument excavated from the Western Han tomb of the Marquis of Ruyin). Kaogu 1978, no.5: 338343.

Yin Hongbing 尹宏兵 (2007). “Rong Cheng shi yu 'Jiuzhou” 《容成氏》與 ‘九州” (Rong Cheng shi and the 'Nine Provinces'), in : Chudi jianbo sixiang yanjiu 楚地簡帛思 想研究 (Chu bamboo and silk manuscript thought studies), vol.3, Wuhan: Hubei jiaoyu chubanshi 湖北教育出版社, pp. 220-236.

Zhao Ping”an 趙平安 (2003). “Chuzhushu Rong Cheng shi de pianming ji qi xingzhi” 楚 竹书《容成氏》的篇名及其性质 (The meaning of the title and the nature of the Rong Cheng shi from the Shanghai bamboo documents). Huaxue 华学 (Chinese studies) $N^{\circ} 6$ [Zijincheng chubanshe 紫禁城出版社]: 75-78.

Zhao Ping'an 趙平安(2009). Xinchu jianbo yu guwenzi guwenxian yanjiu 新出簡帛與古 文字古文獻研究. Shanghai: Shangwu yinshuguan 商務印書館 / Commercial Press, 2009 (includes reprint of “Chuzhushu Rong Cheng shi de pianming ji qi xingzhi” 楚竹书 《容成氏》的篇名及其性质), pp. 248-254.

Zhu Yuanqing 朱淵清 (2004). “'Rong Cheng shi’ Jia zhou, Xu zhou, Xu1 zhou kao” 《容成氏》夾州, 徐州, 敘州考 (Jia province, Xu province and Xul province found in the Rong Cheng shi manuscript), in: Shangbo guan cang Zhanguo Chu zhushu yanjiu xubian 上博館藏戰國楚竹書研續編 (A sequel to the 'Studies of Chu bamboo strips of the Warring States period from the Shanghai Museum'), eds. Zhu Yuanqing 朱淵清 and Liao Mingchun 寝名春. Shanghai: Shanghai shudian, pp. 412-424.

First published under a slightly different title “Yu hua Jiuzhou lun” 禹畫九州論 (Discussion of how 'Yu delineated the Nine Provinces') at the at the Jianbo yanjiu 簡帛研究(Bamboo and Silk forum), 07.08.2003, http://www.jianbo.org/Wssf/2003/zhuyuanqing03.htm 